Historic, archived document

Do not assume content reflects current scientific knowledge, policies, or practices. 

NDER THE AUTHORITY of the McSweeney-McNary Forest Research Act of 22 May, 1928 and subsequent amendments, the Forest Service, U.S. Department of Agriculture, conducts periodic forest surveys of all states to provide up-to-date information about the forest resources of the Nation.

The first forest survey of Vermont was made in 1948 by the Northeastern Forest Experiment Station, with the cooperation of many individuals, forest industries, and state agencies. A second forest survey was completed in 1966.

This third survey was conducted in 1972, again with the cooperation of many individuals and agencies. Special mention is due James Wilkinson, Robert A. Farrington, and Benjamin Hoffman of the Vermont Department of Forests and Parks and their staffs for their continuous assistance and support.

The third inventory of Vermont was directed by Carl E. Mayer, Resources Evaluation unit leader. He was assisted by Joseph E. Barnard, who was responsible for the design of the inventory and sample selection as well as for supervision of data compilation. John R. Peters supervised the photo-interpretation and the data collection by field crews. David R. Dickson applied the generalized data-processing system, FINSYS, to the specific data needs of the Vermont inventory and produced summary tables for the State and by counties and units. Teresa M. Bowers assisted in the inventory design by performing all the calculations necessary for sample-size determination and plot selection. She was responsible for the coordination of key-punching and other data-preparation tasks and the final preparation and statistical checking of tables for the report. James T. Bones, with the assistance of state personnel, collected and compiled the data on timber-products output and industrial utilization of timber. He was assisted in the compilation phase by David R. Dickson and Teresa M. Bowers. Carmela M. Hyland was responsible for ad. ministrative and secretarial services.

Field work was completed in December 1972. Final computer output was available in September 1973. Users of this report who have a need for more detailed information or analysis than is presented here should contact the Resources Evaluation unit, Northeastern Forest Experiment Station, 6816 Market Street, Upper Darby, Pennsylvania, 19082. Users of this report are strongly advised to read carefully the definitions of forest-survey terms and the section on the reliability of the estimates in the appendix of this report.

\section{The Author}

NEAL P. KINGSLEY, research forester, received his bachelor's degree in forestry from the University of New Hampshire in 1961 and his master's degree in forest economics from the same university in 1963. He joined the Northeastern Forest Experiment Station in August 1962 and his resource analyst in the Experiment Station's Resources Evaluation unit at Upper Darby, $\mathrm{Pa}$.

MANUSCRIPT RECEIVED FOR PUBLICATION 18 FEBRUARY 1976 


\title{
The \\ FOREST RESOURCES \\ OF VERMONT
}

\author{
by Neal P. Kingsley
}

\section{CONTENTS}

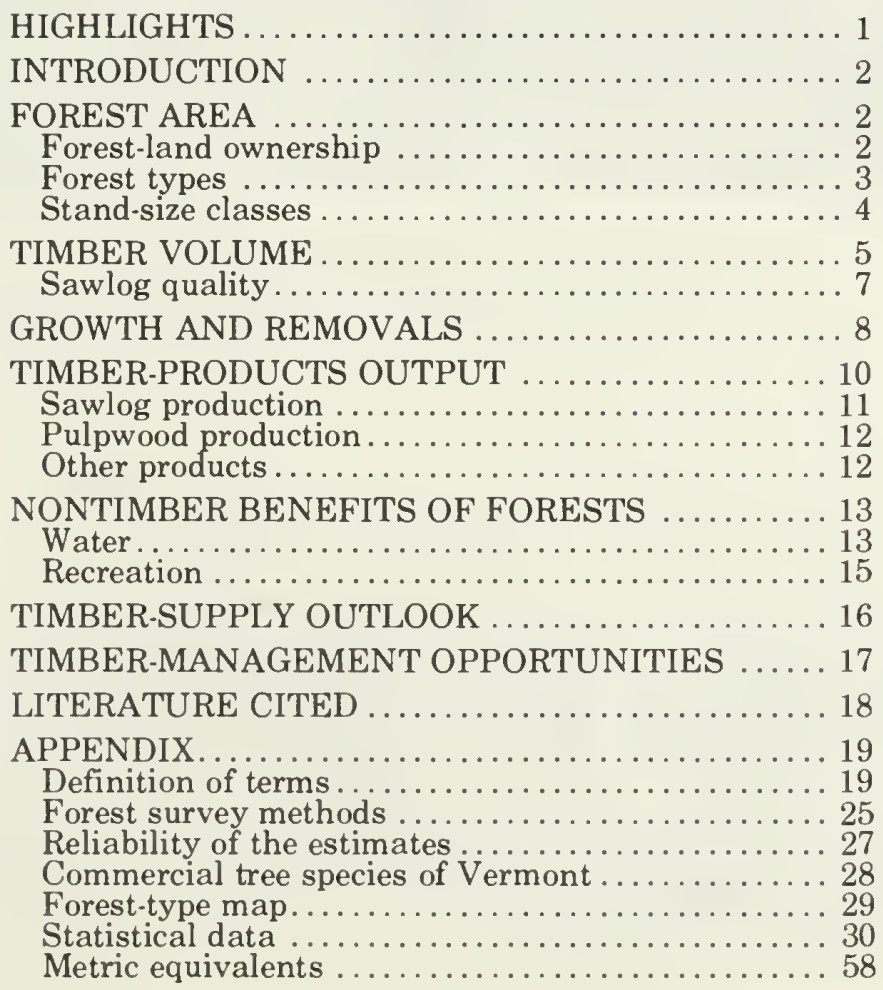




\section{Highlights}

× Commercial forest land area continues to increase. It is now 4,429,900 acres. (See appendix for metric equivalents of units used in this report.)

\section{丈 Ninety percent of Vermont's commercial forest land is privately owned.}

$$
\begin{aligned}
& \text { An estimated } 77,300 \text { owners hold the pri- } \\
& \text { vately owned commercial forest land in Ver- } \\
& \text { mont. The average ownership is } 51.6 \text { acres. }
\end{aligned}
$$

\section{* Although the area of commercial forest land increased only 3 percent, the volume of grawing stock increased 7.5 percent. Saw- timber volume rose 14.5 percent.}

\section{* Sugar maple remains the most abundant species-24 percent of the State's timber volume.}

Sawtimber quality continues to decline: grade-1 sawlogs account for only 1 percent of the pine sawtimber and only 9 percent of the hardwood sawtimber.

\footnotetext{
N Net annual growth of growing stock in Vermont is extremely low-only 2.3 percent of the inventory.
}

\section{丈 Pulpwood production continues to increase steadily, while sawlog production holds con- stant.}
丈 The timber supply is expected to increase by 1.3 billion cubic feet during the next 30 years. forest resource. 


\section{Introduction}

T HIS REPORT presents a discussion and analysis of the results of the third forest survey of Vermont, completed in 1973. The first forest survey of Vermont was completed in 1948 and the second in 1966 (Kingsley and Barnard 1968). Through the years many definitions, procedures, and methods have changed as a result of improved forestinventory and data-processing techniques. This means that, to analyze actual trends between forest surveys, the estimates from the previous survey must be put on a comparable basis with the current survey. The 1948 and 1966 estimates are valid for the procedures and definitions used at those occasions. The changes in commercial forest area and growing-stock and sawtimber volume, after adjustment of the 1966 data to current standards, are:

\begin{tabular}{|c|c|c|c|}
\hline & 1966 & 1973 & Change \\
\hline $\begin{array}{l}\text { Commercial forest land } \\
\text { (thousand acres): }\end{array}$ & 4,295 & 4,430 & +135 \\
\hline \multicolumn{4}{|l|}{$\begin{array}{l}\text { Growing stock volume } \\
\text { (million cubic feet): }\end{array}$} \\
\hline $\begin{array}{l}\text { Softwoods } \\
\text { Hardwoods }\end{array}$ & $\begin{array}{l}1,604.0 \\
2,794.5\end{array}$ & $\begin{array}{l}1,718.0 \\
3,012.2\end{array}$ & $\begin{array}{l}+114.0 \\
+217.7\end{array}$ \\
\hline Total & $\overline{4,398.5}$ & $4,730.2$ & +331.7 \\
\hline \multicolumn{4}{|l|}{$\begin{array}{l}\text { Sawtimber volume } \\
\text { (million board feet): }\end{array}$} \\
\hline $\begin{array}{l}\text { Softwoods } \\
\text { Hardwoods }\end{array}$ & $\begin{array}{l}3,358.0 \\
5,132.7\end{array}$ & $\begin{array}{l}3,875.5 \\
5,845.2\end{array}$ & $\begin{array}{l}+517.5 \\
+712.5\end{array}$ \\
\hline Total & $8,490.7$ & $\overline{9,720.7}$ & $+1,230.0$ \\
\hline
\end{tabular}

\section{Forest Area}

Forest land continues to occupy an increasing share of the Vermont landscape. In 1973, 76 percent of the State's land area was in forest. This represents a 4-percent gain since 1966 and a 20-percent gain since the first forest survey of Vermont in 1948. Today none of Vermont's counties except Grand Isle has less than 56 percent of its land area in forest, and only 3 of these counties are less than two-thirds forested. (Grand Isle County has been excluded from this timber inventory because of its small size and relative unimportance as a timber-producing county.)

Commercial forest land totals 4,429,900 acres or 75 percent of the State's land area. In addition, 63,800 acres are classified as noncommercial forest land. Of this land, 20,300 acres are unproductive. That is, they are not capable of growing 20 cubic feet of wood per acre per year. In Vermont most of this land is on ridgetops or in swamps and bogs. Another 17,500 acres of land is in Christmas-tree plantations. The remaining 26,000 acres are productive reserved forest land. This is land that is withdrawn from timber production through ordinance, statute, or administrative order. This land includes such areas as state parks and other public recreation sites.

All but one of the State's counties have increased in commercial forest area since 1966. The lone holdout, Chittenden County, dropped only 900 acres. Essex County, in the extreme northeastern corner of the State, continues to hold the title of most heavily forested; 93 percent of its area is in commercial forest. Franklin County showed the greatest gain in commercial forest acreage -up 6 percent-24,900 acres-since 1966.

\section{Forest-Land Ownership}

Only 10 percent-441,600 acres-of Vermont's commercial forest land is in public ownership. Of this, 228,600 acres is in the Green Mountain National Forest. Other federal agencies hold only 3,800 acres. The State of Vermont holds 168,200 acres, mostly in State Forests. County and municipal governments hold 41,000 acres.

The $3,988,300$ acres that are privately owned are held by an estimated 77,300 different owners. Of these, 73,900 are individuals, 700 are corporations, and 2,700 are clubs, youth organizations, churches, and similar associations. The average size of commercial forest-land ownerships in Vermont is 51.6 acres. The 33,500 owners who own fewer than 10 acres hold an average of only 1.7 acres, primarily as home sites. This means that those 43,800 owners who hold more than 10 acres hold almost 90 acres on average.

Of the 73,900 individuals who own forest land in Vermont, farmers account for only 10 percent; they own 589,000 acres-20 percent of the acreage owned by individuals. Skilled laborers account for more owners than any other group-21,000-nearly 29 per- 
cent of all individual owners. However, they do not hold a large share of the acreage held by individuals. The largest share of acreage owned by individuals is owned by professional people. Though they account for less than 12 percent of the individual owners, they hold 22 percent of the commercial forest land held by individuals.

Of the 700 corporations that own commercial forest land in Vermont, 500 are engaged in real estate development. These corporations own more than 115,000 acres. Forest industries own more than 666,000 acres, yet they account for only about 100 owners. The remaining corporate owners include nonforest industries, nonindustrial businesses, and corporate farms. Together, these owners account for only slightly more than 77,000 acres of commercial forest land.

These estimates of privately owned commercial forest land are based on a canvass of forest-land owners in the State. This canvass was conducted concurrently with the resurvey of Vermont. The results of this study will be published separately.

One of the primary objectives of conducting this canvass was to estimate the volume of timber on privately owned commercial forest land that is now or may in the future be available for timber harvesting. Thirty percent of the present owners of commercial forest land in Vermont have at one time or another harvested timber from their lands. These owners account for 66 percent of the privately owned commercial forest land in Vermont. It is interesting to note, in view of this, that only an estimated 7 percent of the owners own their forest land primarily for timber production. These owners, however, own 19 percent of the privately owned commercial forest land in the State.

\section{Forest Types}

Although the area of commercial forest land in Vermont increased nearly 135,000 acres during the 7-year period, the proportion of commercial forest land in the various forest types has changed very little (fig. 1). The only proportionate increases were in spruce/fir (up to 18 percent) and the oak/pine type (up to 2 percent)-each a 1-percent gain over 1966.

The only decrease was in the elm/ash/red

Figure 1.-The area of forest types has changed little.

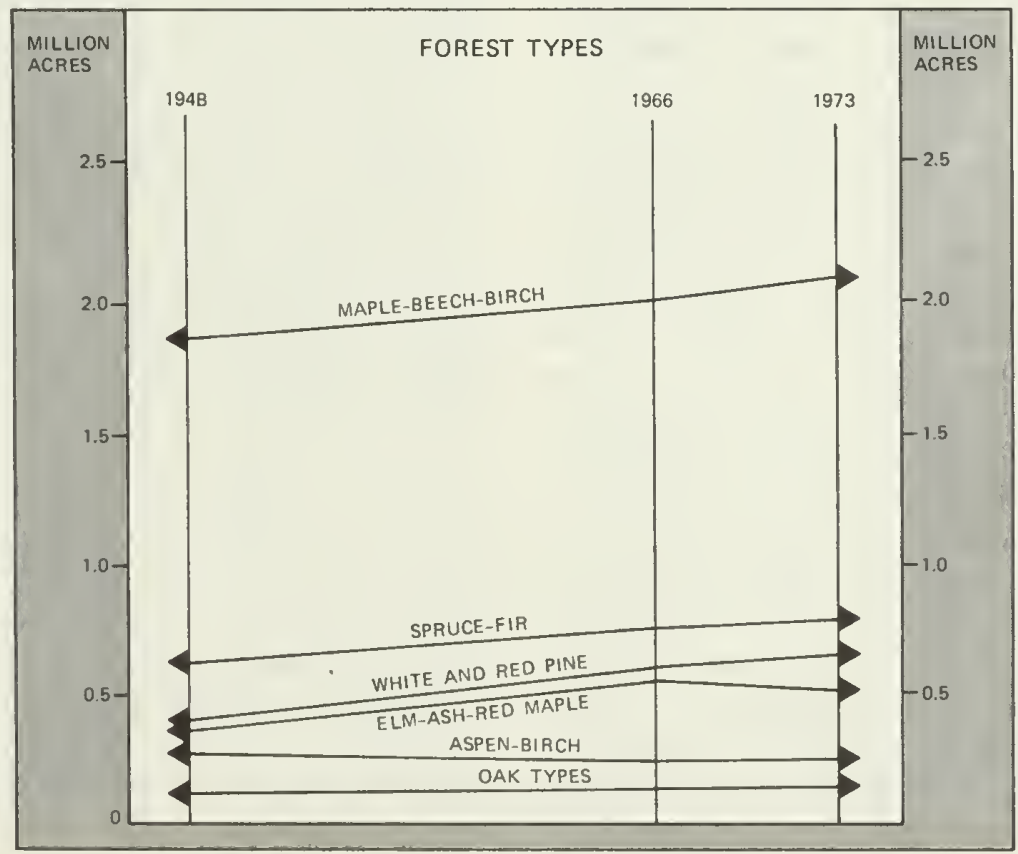




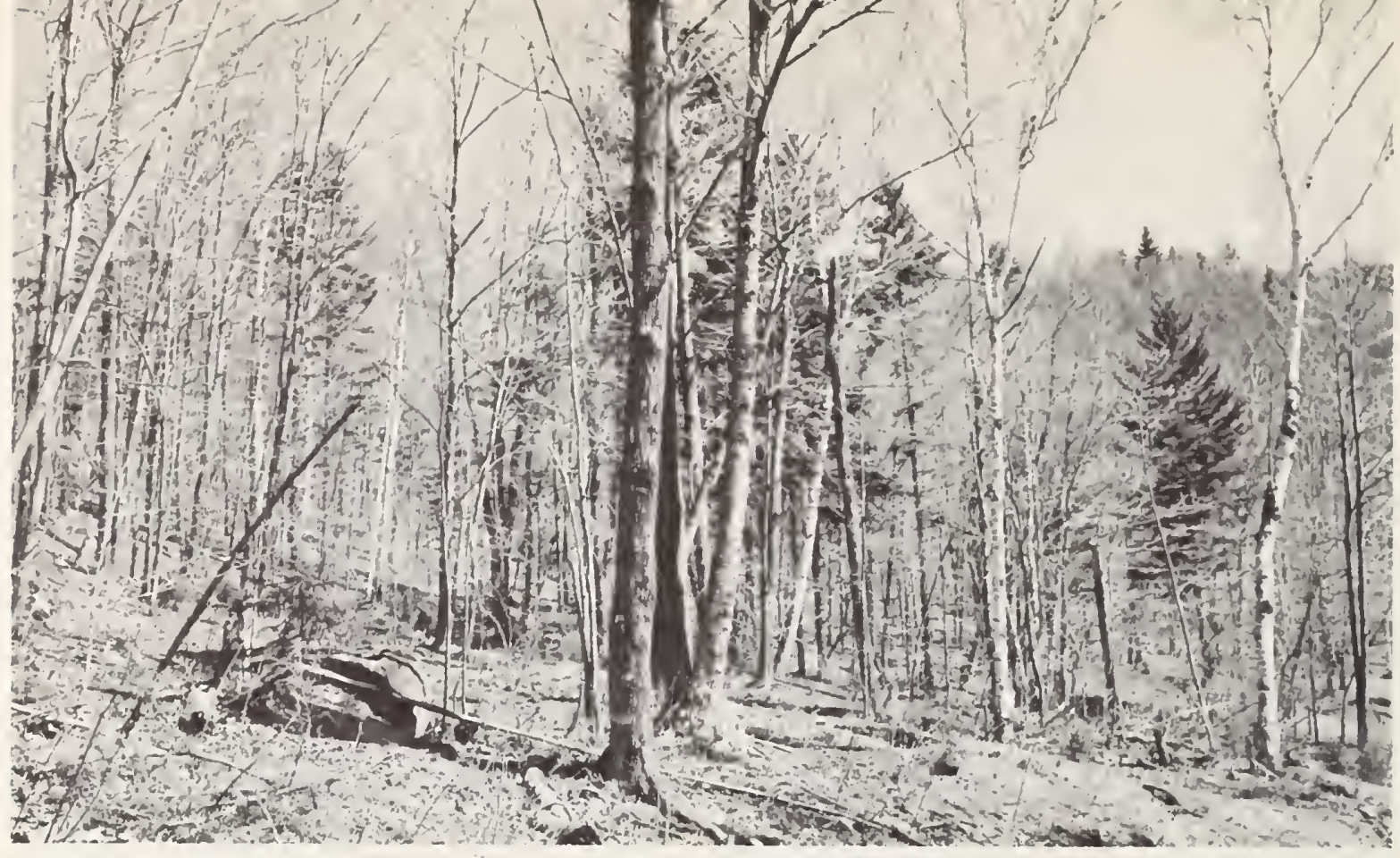

\section{A maple/beech/birch stand with red maple as an important component.}

maple type. This type lost nearly 50 thousand acres, dropping from 13 percent of the area in 1966 to 11 percent in 1973 . The most logical explanation for the decrease in the area of $\mathrm{elm} / \mathrm{ash} / \mathrm{red}$ maple seems to be linked to changes in species composition as this type matures into sawtimber-size stands.

A characteristic of red maple, the major species in this type, is that, though it has a rapid rate of growth in the poletimber and smaller sizes, it does not sustain this rate of growth as the trees mature. When red maple is associated with the northern hardwood species, the same stand that was typed as elm/ash/red maple when it was poletimber size is often typed as maple/ beech/birch as a sawtimber-size stand because the red maple has failed to keep pace with the sugar maple and beech. This conclusion is reinforced by the fact that the maple/beech/birch type, the most prevalent hardwood type in Vermont, increased some 78,000 acres. Undoubtedly much of this increase can be ascribed to this naturally occurring type change in maturing stands.

\section{Stand-Size Classes}

In 1966 the forest survey found 41 percent of the stands classified as sawtimber, 35 percent as poletimber, and 24 percent as seedling-sapling stands and nonstocked areas. The 1973 forest survey, however, found that the distribution of stand-size classes has changed. While the area in sawtimber stands rose only from 41 percent in 1966 to 46 percent in 1973 , the area in poletimber stands plummeted from 35 percent to 22 percent. The area in seedling-and-sapling stands rose from 24 to 32 percent of the State's commercial forest-land area (fig. 2).

The cause of this apparent turnaround in the trend is linked to timber demand during the period. From 1965 through 1972 the saw. log harvest in Vermont remained essentially constant, and demand for veneer logs declined. However, during this same period the demand for round pulpwood rose 20 percent (Bones and others 1974). This continuing low demand for sawlogs has meant that many white pine and maple/beech/birch 


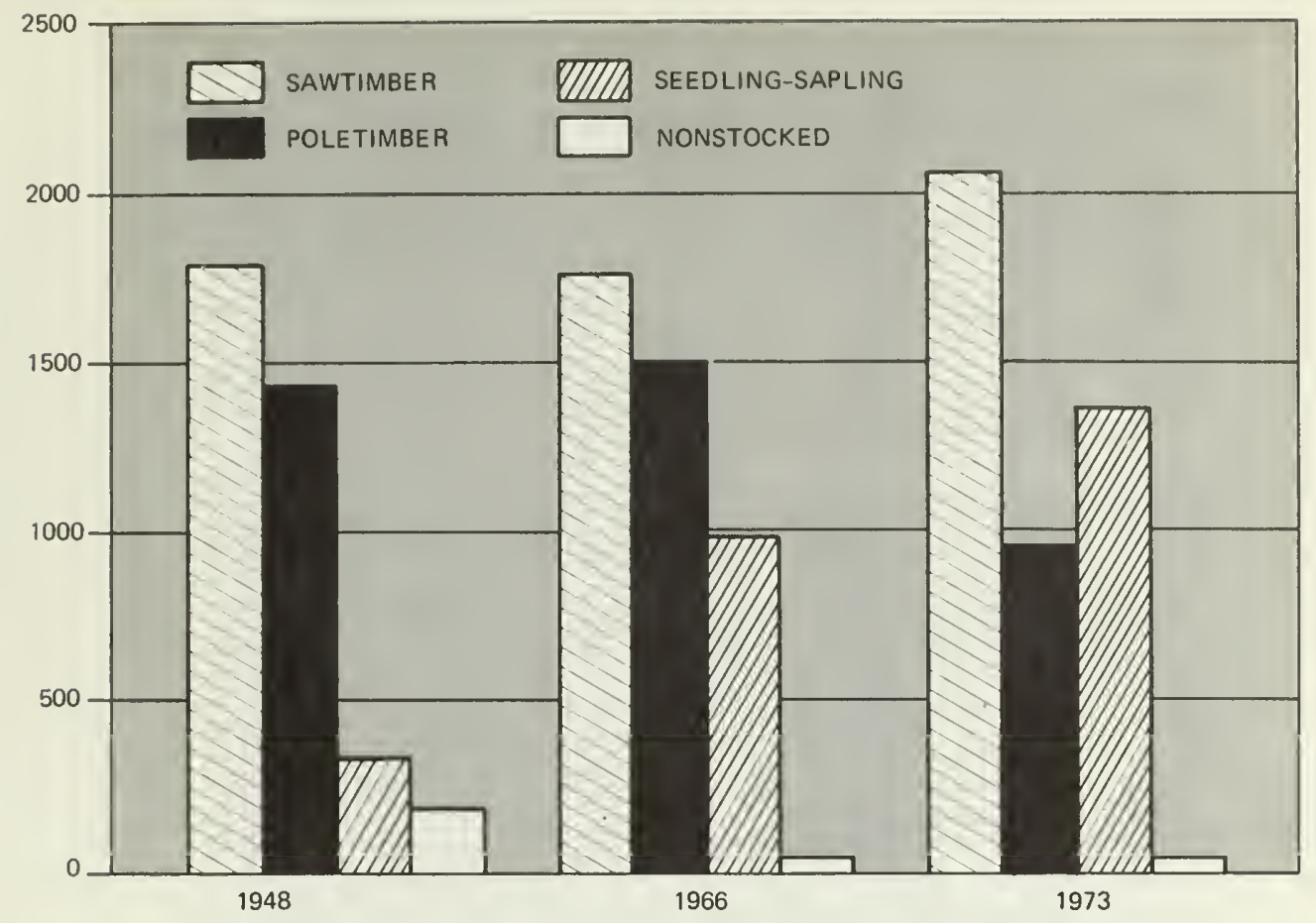

Figure 2.-Changes in stand-size class distribution in three inventories in Vermont.

stands, the major sawtimber-producing types, have been left to grow.

On the other hand, the higher level of demand for pulpwood has apparently meant that stands of spruce/fir and elm/ash/red maple were harvested. These two types produce the bulk of the pulpwood harvest in Vermont. Because individual tree size is not of major concern in pulpwood production, and because of the condition and location of many of the stands in these timber types, it is often most economical as well as silviculturally sound practice to harvest the entire stand either by clearcutting or by a shelterwood system.

These conclusions are further strengthened by the fact that, in 1973, 67 percent of the white pine type and 55 percent of the maple/beech/birch type was in sawtimber-size stands. On the other hand, 47 percent of the spruce-fir and 39 percent of the elm/ash/red maple was in seedling-sapling stands.

\section{Timber Volume}

Although the area of commercial forest land has increased only 3 percent since 1966 , the volume of growing stock gained more than 7.5 percent in the same period. In 1973 , the volume of growing stock in Vermont stood at 4.7 billion cubic feet, up from 4.4 billion in 1966. Since 1948 the volume of growing stock in the State has risen more than 40 percent. Softwood and hardwood growing stock posted nearly identical gains. Softwood growing stock was up 7.1 percent since 1966 and hardwood up 7.8 percent. However, over the longer period, since 1948 , the softwood growing-stock inventory gained more than the hardwood. Softwoods were up over 44 percent while hardwoods gained 38 percent (fig. 3 ).

The most impressive increase in timber volume was in sawtimber. The volume of sawtimber in Vermont rose from 8.5 billion board feet in 1966 to 9.7 billion in 1973-a 
Figure 3.-Changes in growing-stock volume in three inventories in Vermont, by major species.

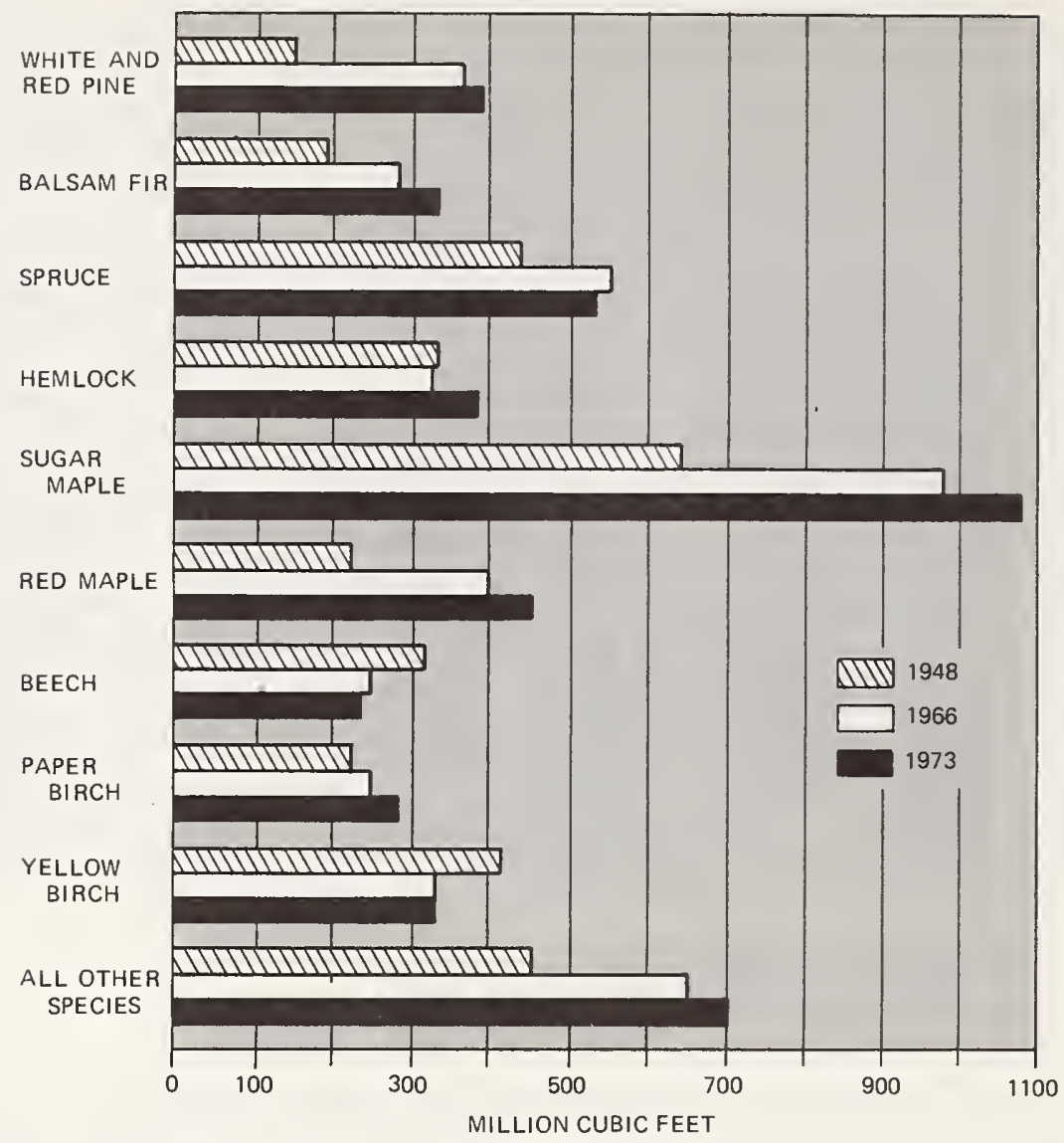

jump of 14.5 percent. Sawtimber gained only 1 percent during the $1948-66$ period.

Sugar maple remains the most abundant species in the State, with 1.1 billion cubic feet or 23 percent of the State's total timber volume. Northern red oak showed the greatest increase in volume, rising from 86.2 million cubic feet in 1966 to 113.1 million cubic feet in 1973, a gain of 31 percent in the relatively short period of 7 years. (A similar increase was also observed in New Hampshire.) Low demand for this species seems to be the major factor influencing this increase. Sawtimber-size northern red oak registered a 32-percent increase since 1966. Sawtimber-size sugar maple remains by far the most abundant species in terms of sawtimber volume. In 1973 the volume of sugar maple sawtimber stood at 2.3 billion board feet, up from 1.9 in 1966 . No other hardwood species exceeds 1 billion board feet in total volume (fig. 4).
Although it was the only softwood species to show a decline in volume, spruce is still the most abundant softwood. The volume of spruce rose from 440.0 million cubic in 1948 to 549.1 million in 1966 . It then declined to 532.3 million in 1973 , a drop of 3 percent for the 1966-73 period. After a decline from $1,421.9$ million board feet in 1948 to $1,093.6$ million in 1966, the spruce sawtimber volume has increased slightly since 1966 and stood at 1,142.0 million board feet in 1973. Of all the softwood species in Vermont, spruce is the most in demand, mostly for pulpwood. These changes reflect this consistent demand.

Several other species showed significant increases in volume from 1966 to 1973 . Hemlock showed a gain of 16 percent in growingstock volume and a 31-percent increase in sawtimber volume. Although white pine showed less than a 5-percent gain in growing-stock volume, the volume of white pine 
Figure 4.-Changes in sawtimber volume in three inventories in Vermont, by major species.

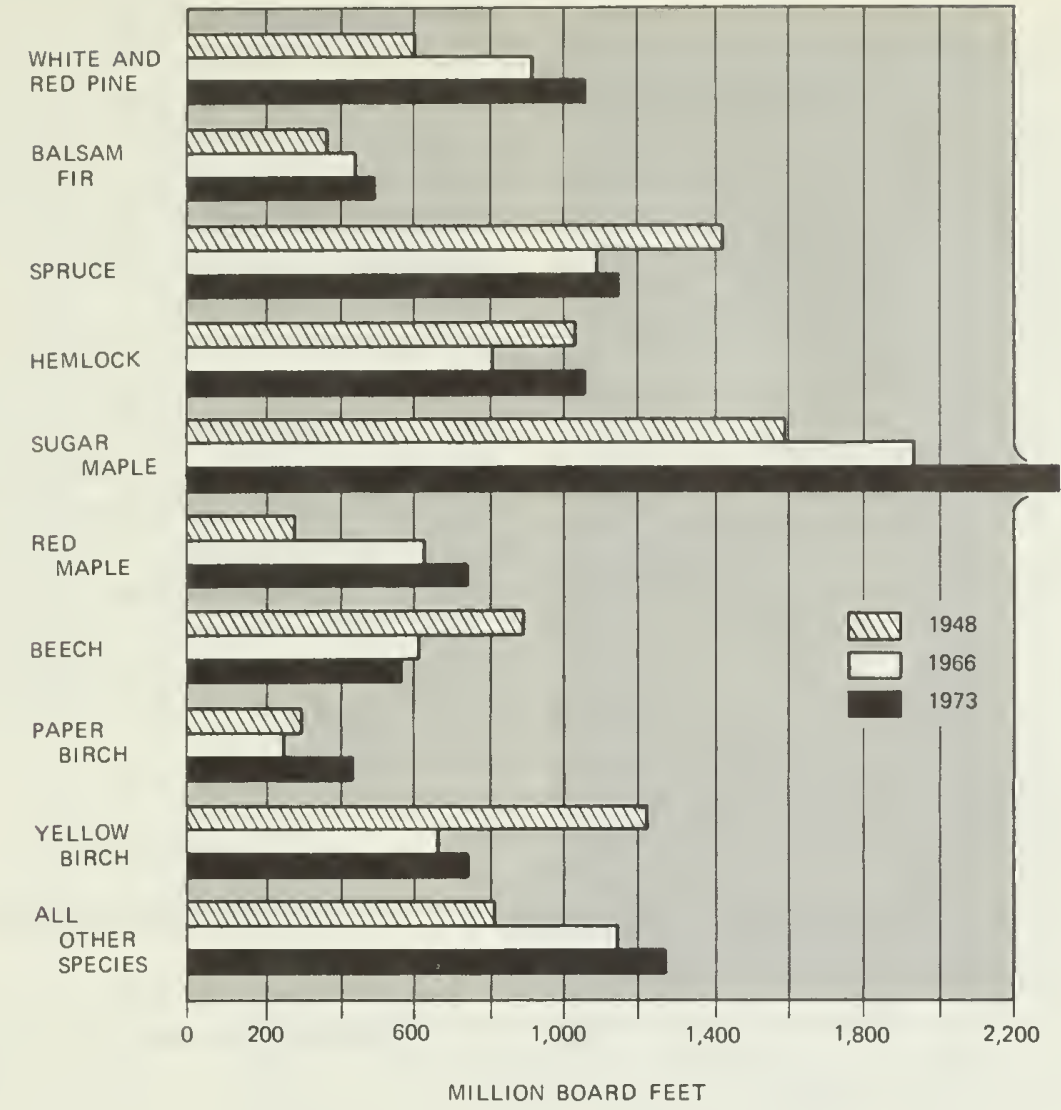

sawtimber gained 17 percent. Both of these increases are a reflection of the increased area of sawtimber-size stands in the State and the consistent low level of demand for sawtimber. Paper birch sawtimber rose 31 percent from 1966 to 1973 . This also is a reflection of the continuing low demand for sawtimber. Although yellow birch sawtimber registered only an 11-percent gain for the period, this is significant because it reverses the earlier trend.

From 1948 to 1966 the yellow birch sawtimber inventory fell from $1,225.4$ million board feet to 664.9 million. But by 1973 it was up to 736.5 million board feet. Yellow birch growing stock remained unchanged from the 1966 level.

This fact indicates that little yellow birch regeneration has been occurring in the recent past and that this apparent upsurge in yellow birch sawtimber volume is not likely to be sustained. Yellow birch requires open mineral soils for successful germination of seed and seedling development. Without fire or logging practices that develop such seedbeds, yellow birch may become a relatively minor species in the future.

\section{Sawlog Quality}

Despite the fact that the volume of sawtimber in Vermont increased 15 percent since 1966 , sawtimber quality continued to decline. In 1966 grade- 1 white and red pine sawlogs accounted for 3 percent of the total white and red pine sawlog inventory. By 1973 this percentage had dropped to only 1 percent, despite a 17-percent increase in the total inventory of white and red pine sawlogs. The hardwood story was similar. In 1966, 12 percent of the hardwood sawlog inventory was in grade-1 logs, but by 1973 only 9 percent was grade-1. The hardwood 
Rough and rotten trees occupy valuable growing space.

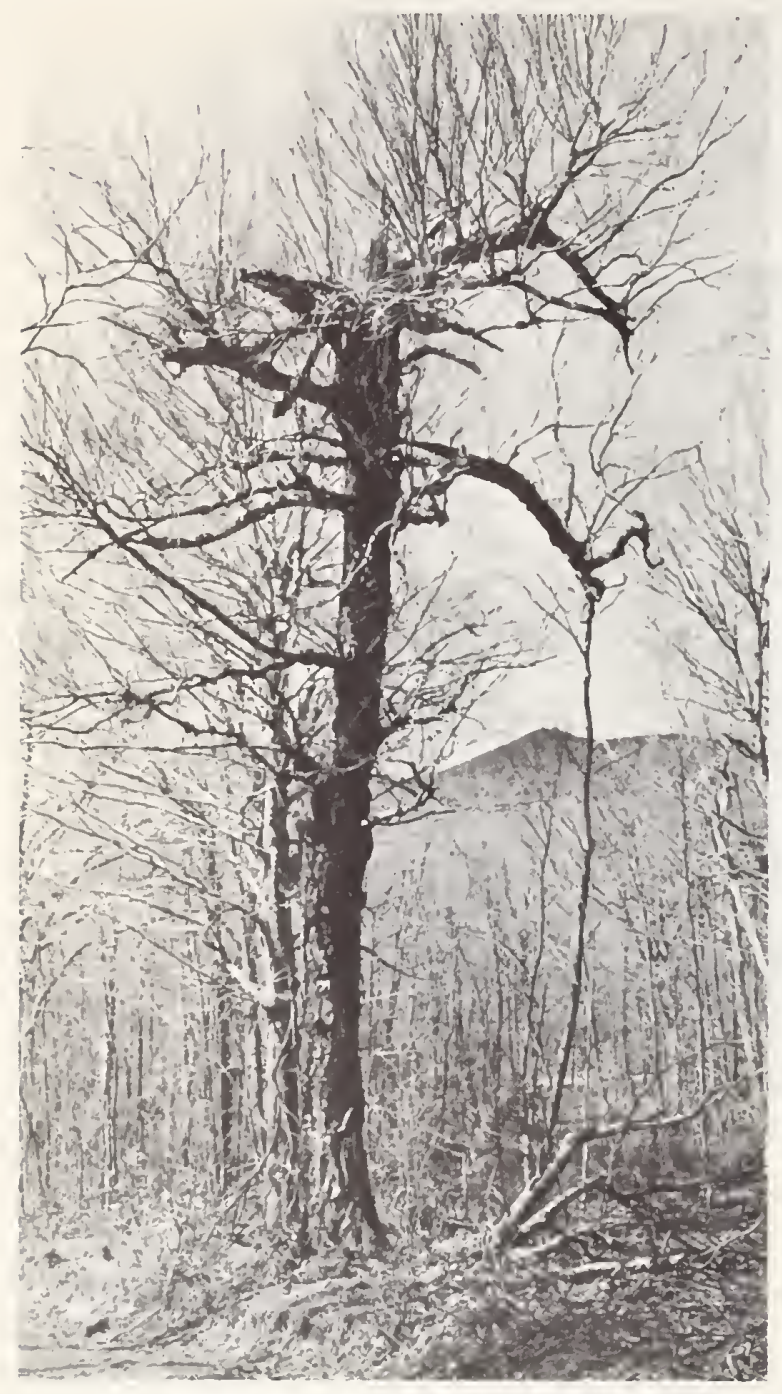

sawlog inventory rose 14 percent during the period.

This decline in sawlog quality was not limited to a few species. In fact, every major species showed a decline in the percentage of the inventory in grade- 1 and -2 sawlogs (fig. 5). What caused this decline? There seem to be two major causes: continued high-grading of sawtimber stands and an increased inventory of small-diameter sawtimber trees. When stands are high-graded, only the best stems are harvested, and the poorer stems are left to grow. The net effect is stands that contain poorer and poorer trees. The increase in the inventory of small sawtimber trees, though sometimes another consequence of high-grading, is primarily the result of the increase in the area in sawtimber stands. A grade-1 sawlog must have a minimum diameter inside bark at the small end of 13 inches. It is highly unlikely that a 14-inch dbh tree could contain such a log. Sixty-three percent of Vermont's sawtimber inventory is in trees smaller than 15 inches dbh.

The recent. development of tree-length integrated logging systems in the State may help to slow the practice of high-grading. Commonly, in tree-length systems, entire trees are skidded to a landing where the quality material is bucked out and the remainder is utilized for pulpwood or other products for which log quality is not a major consideration.

\section{Growth and Removals}

Growth and removals of timber from the inventory can be discussed in several different ways. When it is necessary to understand how the inventory has changed, we discuss the average annual growth and removals. This is the estimated volume of growth or removals for a hypothetical average year during the period between inventories.

In other cases it is necessary to ask: are the growth or removals for the inventory year representative of the average or of the trend during the period between inventories? In this case we compared the average annual growth or removals with the trend (table 20) or actual removals (table 27) for the inventory year. The volume of growth or removals that would be consistent with the average over the period is called trend-level growth or removal. By comparing this estimate, say for removals, with the reported actual volume removed, one can determine whether or not the inventory year was typical of the trend or if it was higher or lower than the trend. This comparison can be very important when predicting or projecting future removals. 
The volume of growing stock in Vermont increased 332 million cubic feet, and sawtimber increased 1.2 billion board feet, from 1966 to 1973. In 1965, 42.2 million cubic feet of growing stock were removed; and in 1972, 48.0 million were removed. Annual net growth of growing stock was 2.3 percent of the inventory in both years $-88.6 \mathrm{mil}$ lion cubic feet in 1965 and 106.6 million in 1972.

In 1965 sawtimber removals stood at 130 million board feet, and in 1972 they stood at 165 million. However, neither 1965 nor 1972 was a representative year when compared to the trend of sawtimber removals, as evidenced by the estimates as adjusted to the then-existing trends. Removals in 1965 were well below the mid-60s trend while those for 1972 were well above the trend of previous years. Thus, when we adjust these removals to the trend level we see that sawtimber removals have not been increasing, but rather have been on the decline from 248 million board feet in 1965 to 118 in 1972. However, the sawtimber growth rate remained steady at 2.7 percent of the inventory in both years.

During the 1965-72 period, annual net growth of growing stock in Vermont averaged 99.2 million cubic feet. Although this is an increase of 16 million cubic feet per year over the 1947-65 period, growth as a percentage of the inventory remained unchanged at 2.2 percent during the 1965-72 period versus 2.1 percent for the 1947-65 period. Sawtimber growth averaged 301 million board feet per year during the 196572 period. This too was essentially unchanged at 3.1 percent of the sawtimber inventory.

Average annual net growth of growing stock in Vermont is extremely low-only 24 cubic feet per acre per year. This fact is vividly illustrated by comparing the com-

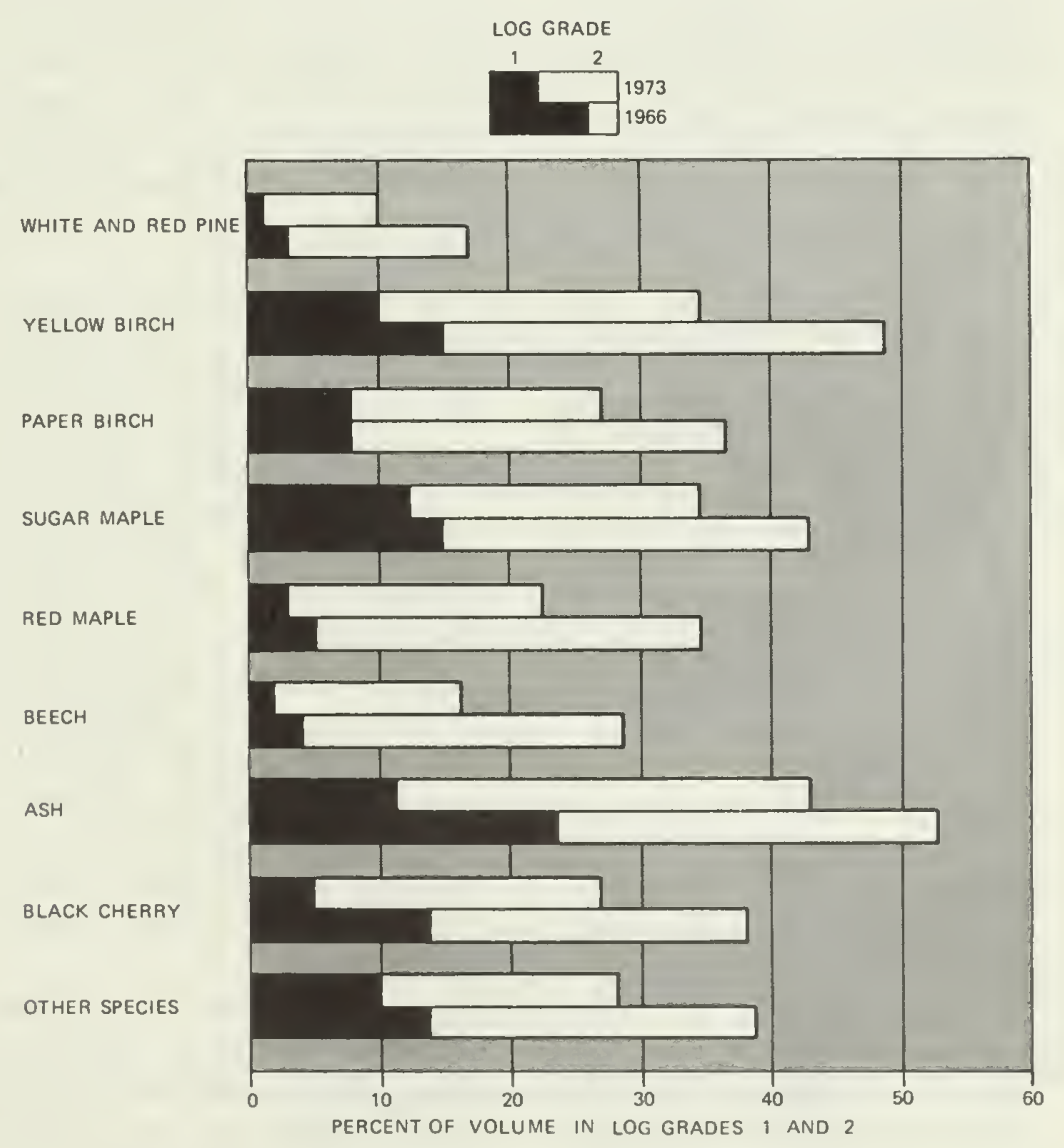

Figure 5. - The decline in sawlog quality is not limited to a few species. 
ponents of growth in Vermont with the components in the five other New England states. In these states the average acre of commercial forest land produces an average of 51 cubic feet of wood per year and loses 7 feet to cull increment (the volume in trees of too poor quality to be considered growing stock) and 6 feet to mortality, for an average annual net growth of 38 cubic feet per acre per year. In Vermont, however, the story is much different. The average acre of commercial land in Vermont produces only 41 cubic feet per acre per year, but loses nearly 7 cubic feet to mortality and 10 cubic feet to cull increment for an average annual net growth of only 24 cubic feet.

Why should annual net growth in Vermont be so much lower than that in the rest of New England? The answer to this question lies in the condition of the State's present timber stands rather than in the productive potential of its forest sites. In fact, over 30 percent of Vermont's commercial forest land is considered as capable of producing more than 85 cubic feet of wood per acre per year. In the other 5 states, 38 percent of the area is as productive. One acre in 4 in Vermont is poorly stocked with growingstock trees. Yet, only 4 percent of all stands are poorly stocked with all trees. This means that valuable growing space is being occupied by inferior trees. Almost 30 percent of all of the live trees in the State over 5 inches $\mathrm{dbh}$ are considered rough and/or rotten. By comparison, in the other 5 New England states only 15 percent are rough and/or rotten.

The volume of each of the components of average annual net change in growing stock for the period 1965 through 1972 is shown below:

\begin{tabular}{lcc} 
& $\begin{array}{c}\text { Million } \\
\text { cubic feet }\end{array}$ & $\begin{array}{c}\text { Cubic feet } \\
\text { per acre }\end{array}$ \\
Accretion & 94.9 & 21.4 \\
(growth on surviving trees) & 74.5 & 16.8 \\
Ingrowth & & \\
(volume of growth that & & \\
became pole-sized) & 169.4 & 38.2 \\
$\quad$ Gross growth & -42.3 & -9.5 \\
Cull-tree increment & -27.9 & -6.3 \\
Growing-stock mortality & 99.2 & 22.4 \\
$\quad$ Net growth & 51.8 & -11.7 \\
$\quad$ Removals & 47.4 & 10.7 \\
\cline { 2 - 3 } Net change in theinventory &
\end{tabular}

\section{Timber-Products Output}

The timber-products-output estimates shown in tables 25 through 28 should not be confused with the estimates of annual timber removals shown in tables 20,21, and 23 . In this section of the report actual production data obtained from the Vermont Department of Forests and Parks and similar data gathered as part of this resurvey are used to analyze the 1972 timber harvest and output of timber products. Data presented in tables 20,21 , and 23 are developed from the remeasurement of permanent sample plots. These tables represent the 1972 growthand-removal situation as indicated by the trend between 1965 and 1972. For this reason slight differences exist between the two sets of data.

Actual production data for a specific year are most useful for analyzing the distribution of timber removals into various categories. Growth-and-removals data based on the trend over the period between inventories are used to analyze the changes in the inventory. In this analysis it is important that the data being analyzed do not represent a typical year.

In 1972, 48.0 million cubic feet of growing stock was removed from Vermont's commercial forest land. Of this volume $32.9 \mathrm{mil}$ lion cubic feet was utilized for timber products. An additional 15.1 million cubic feet was removed as logging residues and other removals. The 32.9 million cubic feet of growing stock that was harvested was below the 35.9 million harvested in 1965 . Thus, timber-products output continued to decline in Vermont. The 1972 output of timber products totaled 43.3 million cubic feet. This included both growing-stock material (32.9) and nongrowing-stock material (10.4) such as tops, limbs, and sound material from rough, rotten, or dead trees as well as plant byproducts.

In 1972, Vermont harvested less than half its annual net growth for that year. This was true for both softwoods and hardwoods. However, there were two notable exceptionsspruce and beech. In both of these species, 
timber removals exceeded growth. For spruce the harvest was only slightly greater than growth; but for beech, removals were more than twice growth.

Most significant in both cases, a reduction in timber mortality could easily have covered the deficit. For spruce a reduction in mortality of only 2 percent would have been nearly sufficient. For beech a reduction of 40 percent would have provided the wood necessary to make removals equal growth. In fact, mortality of beech growing stock was 1.4 times greater than removals and about 3 times growth (fig. 6). It should be noted that the unusually high beech mortality is the result of the beech scale-nectria complex. Nonetheless, a concerted effort should be made to utilize this diseased material rather than to lose it to mortality and subsequent decay. For many major species the annual mortality is high in relation to growth and removals. Such high mortality also reflects the high proportion of rough and rotten trees in Vermont stands.

\section{Sawlog Production}

Sawlog production in 1972 totaled 125 million board feet, up 10 million feet from 1965 (fig. 7). Although production rose slightly, the trend to fewer but larger sawmills continued as the number of mills dropped from 191 in 1965 to 170 in 1972 . Hardwoods accounted for 56 percent of the 1972 sawlog production. Of the 69.9 million board feet of

Figure 6.-Growth, removals, and mortality of growing stock, by major species, 1972.

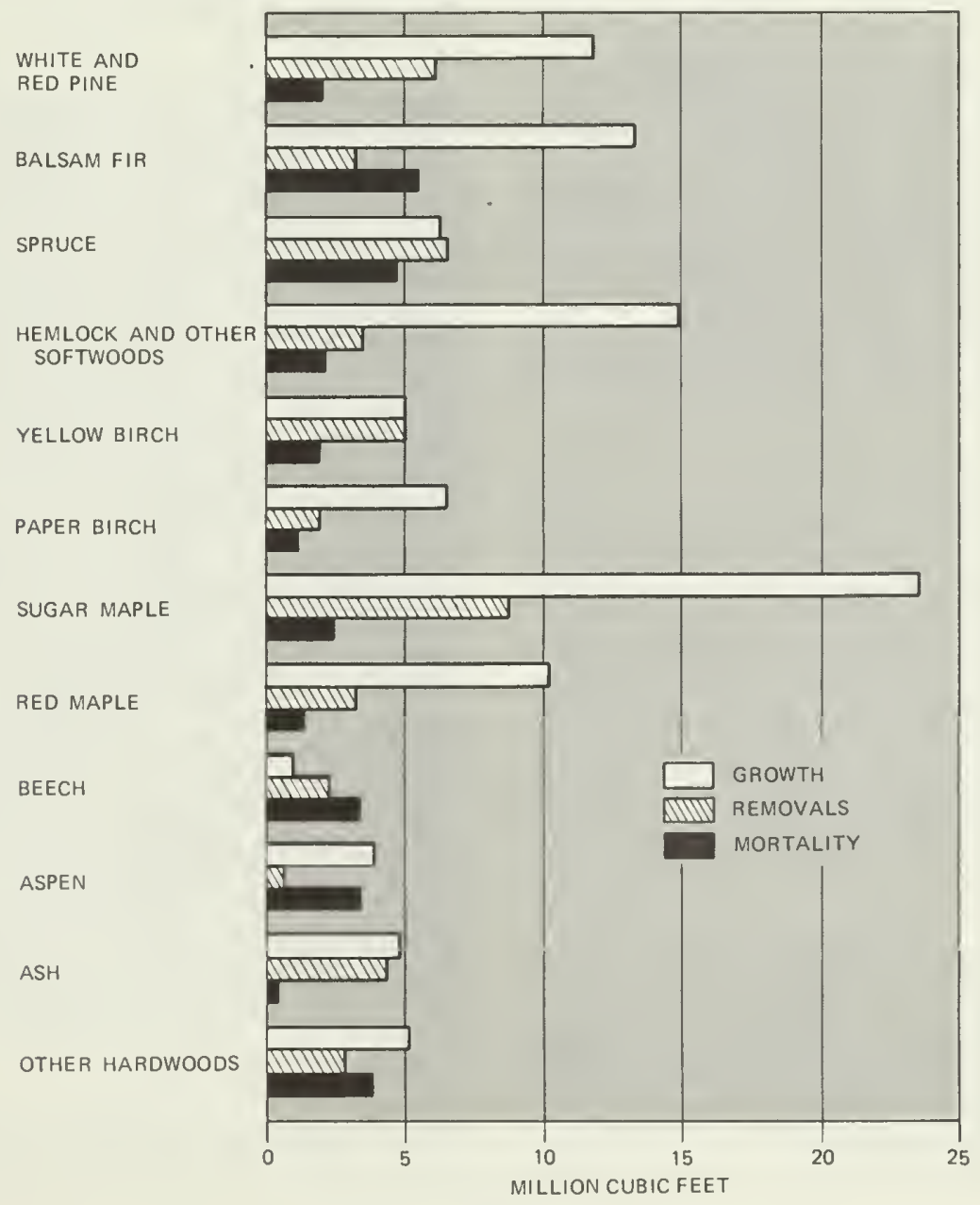




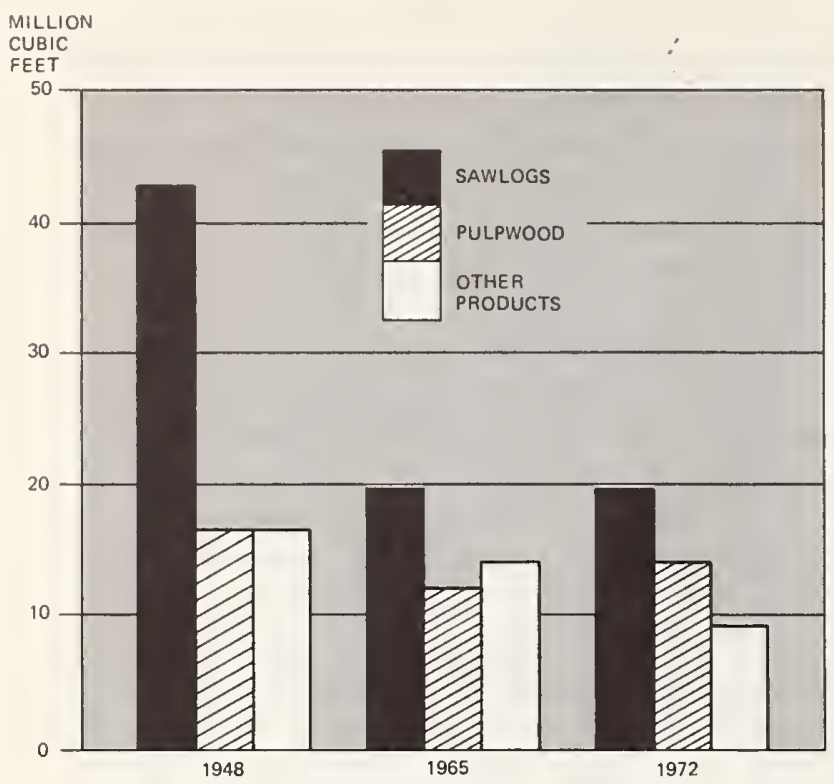

Figure 7.-Production of major timber products in Vermont in 1948, 1965, and 1972.

hardwood sawlogs produced, sugar or hard maple accounted for 33.4 million board feet -48 percent of the hardwood production. Second-place honors went to yellow birch with 11.6 million feet-17 percent of the hardwood output. Of the 55.2 million board feet of softwood sawlogs harvested, white pine accounted for 29.0 million-nearly 53 percent.

\section{Pulpwood Production}

Although Vermont has only one small woodpulp mill, pulpwood production continued to increase steadily. In 1972, pulpwood production from all sources totaled 166,604 cords. Of this total, 31,085 cords were produced from plant byproducts, principally chipped sawmill slabs and edgings. The remaining 135,519 cords were produced from roundwood, trees harvested to produce pulpwood, or portions of trees harvested for other products.

Most of the round pulpwood harvested in Vermont is hardwood-about 58 percent. Most of this consists of maple, beech, and birch. Of the 42 percent of round pulpwood production that is softwood, most is spruce and fir-about 82 percent.

Pulpwood production in Vermont rose from only 38,500 cords in 1928 to 197,172 cords in 1948 and then fell to 173,800 cords in 1963. It then began a nearly steady decline to 142,100 cords in 1969 . By 1972 production had risen to 166,600 cords, and by 1974 , the most recent year for which pulpwood production data are available, production stood at 258,500 cords.

\section{Other Products}

Other products in Vermont include veneer logs, poles and posts, turnery bolts, wooden bowls, clapboards, and pre-cut log cabins as well as fuelwood. In 1972, these uses of wood accounted for $9,431,000$ cubic feet of the State's output of timber products. This total is down from the $14,156,000$ cubic feet produced in 1965 because of the substantial decline in both veneer-log and fuelwood production.

Fuelwood production in 1972 was down substantially from the 1965 output $-6,787,000$ cubic feet in 1965 compared to $4,335,000$ in 1972. The consumption of fuelwood as a home-heating fuel has been declining rapidly since World War II. However, the recent shortages of petrochemical fuels, particularly hard felt in the Northeastern States, may stimulate the use of wood as fuel again.

Production of veneer logs dropped from 15 million board feet in 1965 to only 7 million in 1972. This halving of production accompanied a similar 50-percent drop in the number of veneer plants operating in Vermont from 8 in 1968 to 4 in 1972. Two of the State's plants produce commercial or face veneers for furniture and doors. One of the remaining plants produces container veneers while the other produces specialty veneers. Specialty veneers are used in the manufacture of such products as tongue depressors, popsicle sticks, and toothpicks. Three species-white birch, yellow birch, and beech-traditionally account for the lion's share of Vermont's veneer-log production. In 1972, while more than 10 species of veneer logs were produced, these three species accounted for 71 percent of the production.

Two Vermont forest industries, novelty fencing and pre-cut log cabins, have enjoyed 
growing markets for their products in recent years. The production of fence posts totaled 429,000 cubic feet, most of which was for novelty fencing. The production of pre-cut cabins consumed about 5 million board feet of white pine, red pine, and spruce in 1972.

Despite the fact that timber-products production has been declining in Vermont in recent years, wood-based industries remain an important segment of the State's economy. According to the 1972 Census of Manufactures, there were 850 manufacturing establishments in the State, of which nearly one-third were wood-using industries. They include not only the primary industries like sawmills and pulpmills, but also the secondary wood-using industries such as furniture manufacturers, millwork manufacturers, and makers of various paper products.

The wood-using industries of Vermont employed 6,800 people and paid a total payroll of $\$ 48.2$ million. Wood-using establish-

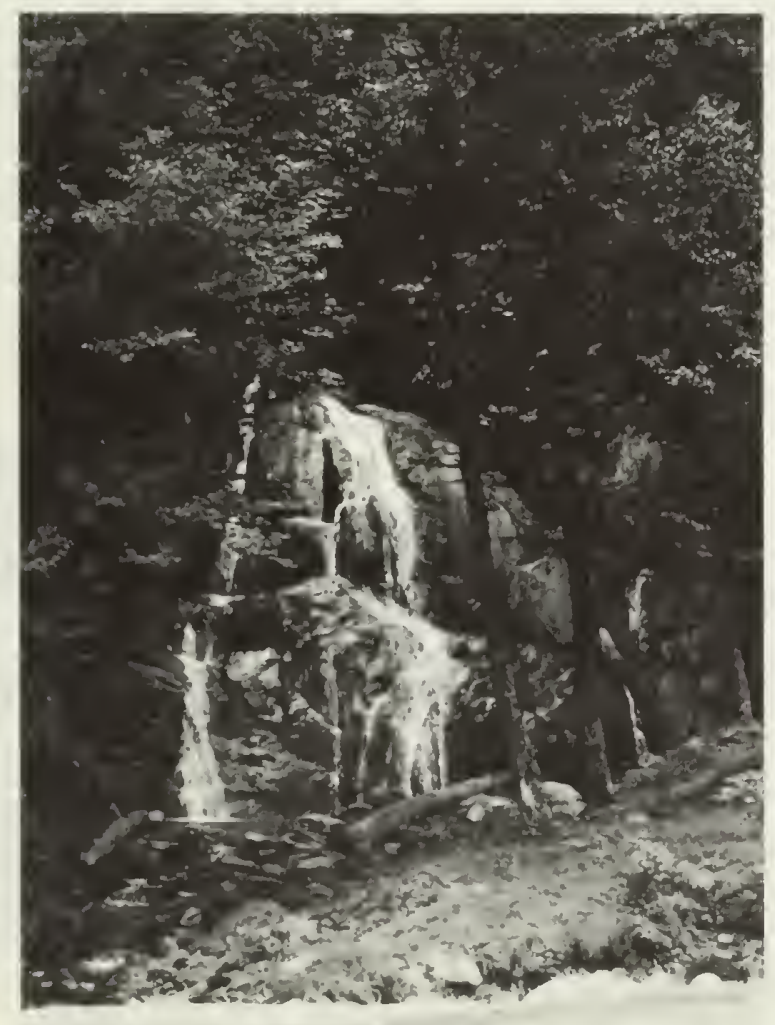

Moss Glen Falls-an example of how water adds to Vermont's natural beauty. ments in Vermont tend to be smaller than the average of all manufacturing establishments in the State. Thus, while wood-using establishments account for about one-third of all manufacturing they account for only 18 percent of all manufacturing employment. The wood-using industries of Vermont in 1972 had a total value of shipments of $\$ 233$ million.

\section{Nontimber Benefits of Forests}

Many products and benefits of forests never enter the market place, yet they add immeasurably to the quality of life.

\section{Water}

The forest lands of Vermont encompass a significant portion of some of the Northeast's most important waterways-the Connecticut and Hudson river systems and the Lake Champlain system. Were the mountains of Vermont not heavily forested, these waterways would be subject to periodic flooding and the waters would not be as attractive because of sedimentation.

In an average year Vermont receives about 40 inches of precipitation, about half in the form of snow. Because the forest acts like a giant sponge to absorb this moisture and prevent excessive runoff, the differences between peak and low flows in the State's waterways is much less than it would otherwise be.

In forested areas stream sedimentation is substantially lower than in regions where other land uses predominate. This is also a result of the absorptive and filtering effect of forest soils. Thus, it is in no small way that forests of Vermont help maintain the State's reputation for clean pleasant streams, lakes, and ponds.

In addition to helping to provide clear streams with a minimum of flooding, forests also help protect public water supplies. Throughout the State there are 177 areas encompassing 42,776 acres of forest land that are managed primarily for watershed protection. 
Recreation is a major industry in Vermont. Cross country skiingrenewed interest in an old sport. Snowmobiling-a new interest and continues to gain in popularity. Hiking-always popular with some.
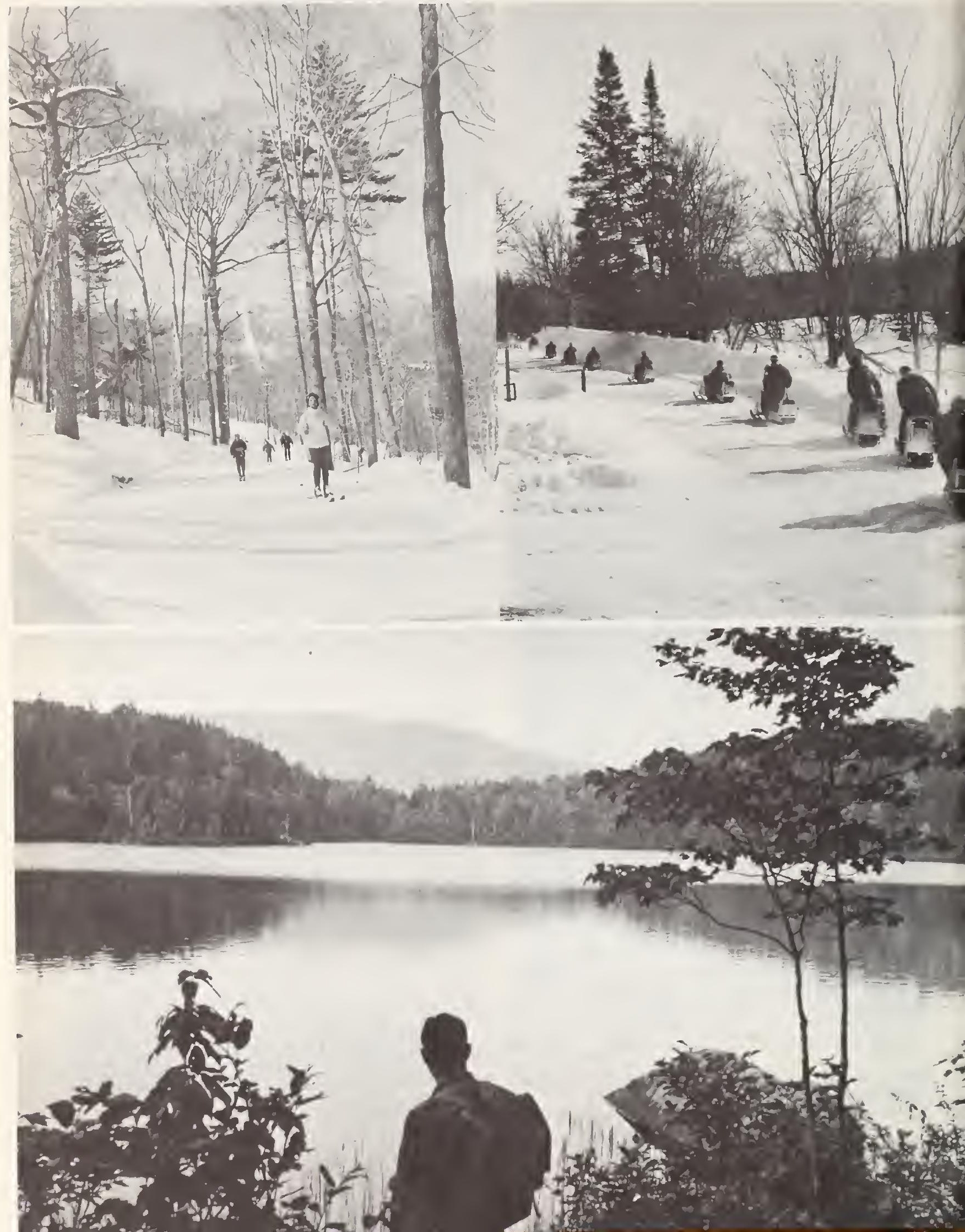


\section{Recreation}

Whether it be skiing, camping, hiking, fishing, hunting, or just plain sightseeing, recreation in Vermont is a major industry. Each year millions enjoy Vermont's vibrant autumn foliage, ski the State's many slopes, or camp among its mountains and streams.

During the 1974-75 ski season an estimated 2.8 million skier-days were enjoyed at the State's 70 developed ski areas. The average skier spent approximately $\$ 30$ per day for lift tickets, lodging, and food. This means that skiers brought nearly $\$ 85$ million into the Vermont economy.

Snowmobiling is a rapidly growing winter pastime. During the 1974-75 snow season, 34,715 snowmobiles were registered in Vermont. A total of $\$ 208,000$ in registration fees was collected. From these fees a total $\$ 84,000$ was spent for the development and maintenance of public snowmobile trails. The remaining $\$ 124,000$ is used for safety and law enforcement of snowmobilers. As of 1974-75 there were approximately 200 miles of public snowmobile trails on State land. The misuse of snowmobiles has been the source of much controversy and concern for a number of years. In addition to serious accidents involving bodily injury and even death, snowmobiles have at times caused considerable damage by knocking over fences or breaking young trees. To combat this, Vermont, like most other snow states, has turned to registration and regulation of snowmobiles.

In Vermont there are nearly 150 developed campgrounds, having a total of more than 7,500 camping sites. In most recent years about one-half million camper-days were spent at the 43 public campgrounds in Vermont. A camper-day is any day or part of a day spent by an individual camping. If we assume that the rate of occupancy at the more than 100 privately owned campgrounds is slightly better than half the rate at public facilities, we can estimate that nearly 1.5 million camper-days are spent in Vermont annually.

Although it is impossible to estimate how many people participate, hiking and backpacking are enjoyed by thousands in Ver- mont each year. An estimated 70,000 people hiked at Camel's Hump State Forest.

The forest lands of Vermont host a variety of fish and wildlife species. In addition to providing enjoyment to sightseers, birdwatchers, and other users of the forest, many species provide recreation in the form of hunting and fishing.

During the 1974-75 license year, nearly 134,000 hunting licenses, 90,000 fishing licenses, and more than 55,000 combination hunting and fishing licenses were sold in Vermont. The fact that about 40 percent of the hunting licenses were sold to nonresidents attests to the fact that Vermont is one of the more desirable hunting and fishing states.

During the 1974-75 hunting season, Vermont hunters killed 12,834 deer, 1,580 of these with bow and arrow. This means that one deer was harvested for every 345 acres of commercial forest land. It is interesting to note that at the turn of the century there were believed to be fewer than 500 deer in the entire State. It is generally agreed that the increase in forest area in Vermont has provided an expanded habitat for deer, fostering an explosion of the deer population, despite ever-increasing hunting pressure.

\section{The wild turkey has been reintroduced recently in Vermont.}

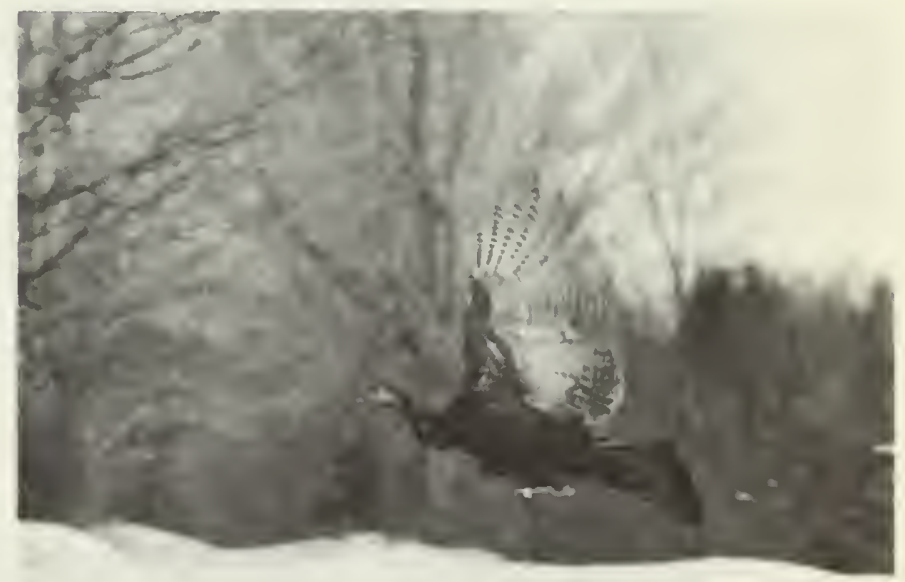


Also during the 1974-75 season, 227 black bears were taken. And 95 wild turkeys were taken in the spring of 1975 during the State's first spring gobbler season. Turkeys have recently been re-introduced in Vermont with considerable success. In addition to these big-game animals, all denizens of the forest, thousands of ruffed grouse, rabbits, and other small game species were also taken.

Because there is no formal market structure, it is often difficult to determine what effect hunters, fisherman, and other recreationists have on a state's economy. However, two studies have been conducted to estimate the economic impact of hunters and fishermen on Vermont's economy in 1970 (Gilbert and Khayami 1973; Gilbert 1975). These studies show that the State of Vermont received $\$ 2,006,479$ from hunting and fishing license sales; $\$ 1,443,680$ of this from nonresidents. Nearly all of these receipts were earmarked for fish and wildlife management programs. However, this is only a small contribution when compared to all expenditures, exclusive of license fees, of hunters and fisherman-a grand total of $\$ 65,148,364$.

Hunters spent an average of $\$ 14$ for each of the 2,865,474 hunter-days in the field. These expenditures include ammunition, food, lodging, clothing, and similar variable expenses plus such fixed expenditures as weapons, recreation vehicles, cabins, land, and so forth. Fishermen spent $\$ 11.67$ for each of the 2,145,029 recreation-days that they pursued their sport. Thus, on average, Vermont hunters and fishermen put $\$ 13$ into the economy of the State for each day they were afield.

When we apply the 2.5 multiplier used by the Vermont Budget Management Department to the $\$ 65$ million expenditures and the $\$ 2$ million in license fees, we find that hunting and fishing have a $\$ 167,500,000$ effect on the Vermont economy. When one considers that this is an estimate of the economic effect of only hunting and fishing and says nothing of skiing, camping, tourism, and the other forms of outdoor recreation, is it any wonder that one of Vermont's biggest industries is recreation?

\section{Timber-Supply Outlook}

All long-range projections are subject to many uncertainties. Long-range projections of timber supply, particularly in the present day, are no exception to this rule. The problem of projecting the supply of timber in Vermont over the next 30 years is complicated by the present economic problems, especially those associated with energy supplies and the current concern for environmental quality. Also, there is the desire of many to spend their leisure hours in a forested setting. In addition, we find that the rate of annual growth of growing stock in Vermont is extremely low, the rate of timber removals even lower than growth, and the forest-based industries in a state of transition.

From 1948 to 1973 the area of commercial forest land in Vermont increased a little more than 700 thousand acres. This increase is expected to continue until about 1980, when the peak of about 4.5 million acres is reached. After 1980 a gradual decline is expected to set in, and by 2003 commercial forest land is expected to total about 4.4 million acres. This slow decline will be the result of further withdrawals for recreational purposes and also as a result of increasing urbanization. It should be noted that many other states in the Northeast have begun to slowly lose commercial forest land after several decades of substantial increases.

Despite the anticipated long-range decrease in commercial forest area, the growing-stock inventory is expected to increase 2.5 billion cubic feet to total 6.0 billion by 2003. Although timber removals from growing stock are expected to increase from 47.8 million cubic feet in 1972 to 127.0 million in 2003, growth of growing stock will also be increasing from 106.6 million cubic feet in 1972 to 154.6 in 2003 (fig. 8). Though this increase may seem substantial in terms of volume, it represents an increase in the rate of growth as a percentage of the inventory of only 0.3 percent. Growing-stock volume per acre is expected to increase from 
bines to generate electricity with steam produced by burning wood chips. It may also be practical on a large scale to power engines with methanol made from wood. The development of particleboards and reconstituted wood products that can utilize a variety of species may provide added opportunities for the utilization of previously seldom used material.

In the woods, things are also changing. In the past, logging operations were usually undertaken for only one product at a time. In the case of timber harvesting for sawlogs, for instance, this meant that substantial numbers of trees that either did not or never would contain sawlogs were left to grow. Today, however, thanks to modern skidders and loaders, logging contractors often harvest several products at the same time. In this way each tree harvested can be put to its best use.

Another innovation that holds proimse is whole-tree chipping. Frequently poorerquality trees were not harvested because their crookedness or limbiness made them difficult to handle and transport. With whole-tree chipping, the entire tree is reduced to chips and blown into a van. Costs and problems associated with handling and transportation are substantially reduced.

Whole-tree chipping, as well as multiproduct harvesting, may often provide forestland owners with the opportunity to harvest previously unmerchantable volume. In this way they may be able to improve the condition of their stands at a profit or at a minimum cost. Previously, needed timberstand-improvement work went undone because it represented a direct cost to the landowner and he might not reap the benefits of such improvements during his tenure.

In some cases the forest manager may conclude that, in order to realize more of a site's timber-growing potential in the future, the present stand should be liquidated and a new stand started. In these cases it may be necessary to clearcut the stand. When properly applied, silvicultural clearcutting requires that all stems of whatever species over 2 inches in diameter must be removed so that these stems do not dominate the site and inhibit the develop- ment of the new stand (Frank and Bjorkbom 1973). Total-tree chipping can be of great help in accomplishing this silvicultural objective too. A frequent criticism of clearcutting is the accumulation of logging slash and debris left on the site. With total-tree chipping, more of the slash goes into product. Also, small trees are not as great a handling problem.

This discussion has centered on forestmanagement opportunities in which timber production is the objective. However, the production of timber is only one of several forest-management objectives. In a State like Vermont, other objectives such as the maintenance of scenic areas, wild. life-habitat management, and watershed protection are often as important or even more important than the output of timber products. Nonetheless, timber will be produced even when the primary objective is something other than timber. The maintenance of a mixture of species and sizes, and the mixture of open areas in the landscape, not only enhance the esthetic quality of an area, but also provide the varied habitat essential to most wildlife species. The maintenance of healthy vigorous stands in watersheds improves soil stability and porosity, which provide more stable steamflow and minimize siltation.

\section{Literature Cited}

Bones, James T., Nicolas Engalichev, and William $\mathrm{S}$. Gove. 1974. THE TIMBER INDUSTRIES OF NEW HAMPSHIRE AND VERMONT. USDA For. Serv. Resour. Bull. NE-35. 25 p., illus.

Bureau of the Census.

1967. CENSUS OF MANUFACTURES, vol. III, part 2. U.S. Dep. Comm., Washington, D.C.

Frank, R. M., and J. C. Bjorkbom.

1973. A SILVICULTURAL GUIDE FOR SPRUCE-

FIR IN THE NORTHEAST. USDA For. Serv. Gen. Tech. Rep. NE-6. 29 p., illus.

Gilbert, A. H.

1975. EXPENDITURE PATTERNS FOR RESIDENT SPORTSMEN IN VERMONT, 1970. Vt. Agric. Exp. Stn. Res. Rep. MP 82. 52 p., illus.

Gilbert, A. H. and S. M. Khayami.

1973. EXPENDITURE PATTERNS OF NONRESIDENT SPORTSMEN IN VERMONT, 1970. Vt. Agric. Exp. Stn. Res. Rep. MP 78. 54 p., illus.

Kingsley, Neal P., and Joseph E. Barnard.

1968. THE TiIMBER RESOURCES OF VER MONT. USDA For. Serv. Resour. Bull. NE-12. 117 p., illus. 


\section{Appendix}

\section{DEFINITION OF TERMS}

\section{Land Area Classes}

Land area.-(a) Bureau of the Census. The area of dry land that is temporarily or partly covered by water, such as marshes, swamps, and river flood plains; streams, sloughs, estuaries, and canals that are less than $1 / 8$ statute mile in width; and lakes, reservoirs, and ponds that are less than 40 acres in area. (b) Forest Survey. The same as the Bureau of the Census, except that the minimum width of streams etc. is 120 feet, and the minimum size of lakes etc. is 1 acre.

Forest land.-Land that is at least 16.7 percent stocked (contains at least 7.5 square feet of basal area) by forest trees of any size, or that formerly had such tree cover and is not currently developed for nonforest use. (Forest trees are woody plants that have a well-developed stem and usually are more than 12 feet in height at maturity.) The minimum area for classification of forest land is 1 acre.

Commercial forest land.-Forest land that is producing or capable of producing crops of industrial wood (more than 20 cubic feet per acre per year) and is not withdrawn from timber utilization. (Industrial wood: all roundwood products, except fuelwood.)

Noncommercial forest land.-Forest land that is incapable of yielding timber crops because of adverse site conditions (unproductive forest land), and productive forest land that is withdrawn from commercial timber use (productive-reserved forest land).

Productive-reserved forest land.-Forest land that is sufficiently productive to qualify as commercial forest land, but is withdrawn from timber utilization through statute, administrative designation, or exclusive use for Christmas-tree production.

Unproductive forest land.-Forest land that is incapable of producing 20 cubic feet per acre per year of industrial wood under natural conditions, because of adverse site conditions.

Nonforest land.-Land that has never supported forests, and land formerly forested but now in nonforest use such as for crops, improved pasture, residential areas, and the like.

\section{Ownership Classes}

National Forest.-Federal lands that have been legally designated as National Forests or purchase units and other lands that are under the administration of the Forest Service.

Federal.-Lands (other than National Forests) that are administered by federal agencies.

State.-Lands that are owned by the State of Vermont or leased to the State for 50 years or more.

County and municipal.-Lands that are owned by counties and local public agencies or municipalities or leased to them for 50 years or more.
Forest industry.-Lands that are owned by companies or individuals operating wood-using plants.

Farmer-owned.-Lands that are owned by farm operators, whether part of the farmstead or not. Excludes land leased by farm operators from nonfarm owners.

Miscellaneous private.-Privately owned lands other than forest-industry and farmer-owned lands.

\section{Stand-size Classes}

Stand.-A growth of trees (see definitions under "Tree Classes") on a minimum of 1 acre of forest land that is at least 16.7 percent stocked by forest trees of any size.

Sawtimber stands.-Stands that are at least 16.7 percent stocked with growing-stock trees, with half or more of total stocking in sawtimber or poletimber trees, and with sawtimber stocking at least equal to poletimber stocking.

Poletimber stands.-Stands that are at least 16.7 percent stocked with growing-stock trees of which half or more of this stocking is in poletimber and/or sawtimber trees and with poletimber stocking exceeding that of sawtimber.

Sapling-seedling stands.-Stands that are at least 16.7 percent stocked with growing-stock trees of which more than half of the stocking is saplings and/or seedlings.

Nonstocked stands.-Commercial forest land that is less than 16.7 percent stocked with growing-stock trees.

\section{Stocking Classes}

Stocking.-The degree of occupancy of land by trees, measured in terms of basal area of trees in a stand compared to the basal area of trees required to utilize fully the growth potential of the land. The actual stocking at a point was evaluated against a standard of 75 square feet of basal area per acre (see definition of basal area under "Tree Measurement and Volume"). The stocking percentage for a sample plot is derived from the stocking for each of 10 points. Three categories of stocking are used:

All live trees.-These are used in the classification of forest land and forest types.

Growing-stock trees. - These are used in the classification of stand-size classes.

Desirable trees.-These are used in the classification of area-condition classes.

The degree of plot stocking is viewed as a range of values rather than single points. A fully stocked stand lies within the range of 100 to 130 percent of the basal-area standard. An overstocked stand contains more than 130 percent. The range for medium stocking is 60 to 100 percent and for poor stocking is 16.7 to 60 percent of the basal-area standard. Forest land with less than 16.7 percent of the basal-area standard is classed as nonstocked. 


\section{Tree Classes}

Forest trees.-Woody plants that have welldeveloped stems and usually are more than 12 feet in height at maturity.

Commercial species.-Tree species that are presently or prospectively suitable for industrial wood products. Excludes species of typically small size, poor form, or inferior quality, such as hawthorn and sumac.

Growing-stock trees.-Live trees of commercial species that are classified as sawtimber, poletimber, saplings, and seedlings; that is, all live trees of commercial species except rough and rotten trees. (See definitions under "Class of Timber.")

Acceptable trees.-Growing-stock trees of commercial species that meet specified standards of size and quality, but do not qualify as desirable trees.

Desirable trees.-Growing-stock trees of commercial species that (a) have no serious quality defects that limit present or prospective use for timber products, (b) are of relatively high vigor, and (c) contain no pathogens that may result in death or serious deterioration before rotation age.

Rotten trees.-Live trees of commercial species that do not contain at least one 12-foot sawlog or two noncontiguous sawlogs, each 8 feet or longer, now or prospectively, and do not meet regional specifications for freedom from defect primarily because of rot; that is, when more than 50 percent of the cull volume in a tree is rotten.

Rough trees.-(a) The same as above, except that rough trees do not meet regional specifications for freedom from defect primarily because of roughness or poor form, and (b) all live trees that are of noncommercial species.

\section{Site-quality Classes}

Site class.-A classification of forest land in terms of inherent capacity to grow crops of industrial wood. Classifications are based upon the mean annual growth of growing stock attainable in fully stocked natural stands at culmination of mean annual growth.

\section{Forest Types}

Forest type is a classification of forest land based upon the species forming a plurality of live tree stocking. The many local forest types in Vermont were combined into the following major forest types:

White and red pine.-Forests in which eastern white pine, red pine, or hemlock, singly or in combination, make up a plurality of the stocking. (Common associates include aspen, birch, and maple.)

Spruce/fir.-Forests in which spruce or balsam fir, singly or in combination, make up a plurality of the stocking. Cedar swamps are also in this type. (Common associates include white-cedar, tamarack, maple, birch, and hemlock.)
Oak/pine.-Forests in which hardwoods (usually red or black oaks) comprise a plurality of the stocking but in which pines comprise 25 to 30 percent of the stocking.

Oak/hickory.-Forests in which oaks, singly or in combination, make up a plurality of the stocking, except where pines make up 25 to 30 percent, in which case the stand would be classified oak/pine. Hickory is seldom present in Vermont. (Common associates include elm and the maples.)

Elm/ash/red maple.-Forests in which elm, ash, or red maple, singly or in combination, comprise a plurality of the stocking. (Common associates include beech, white pine, basswood, and sugar maple.)

Maple/beech/birch.-Forests in which maple, beech, or yellow birch, singly or in combination, comprise a plurality of the stocking. (Common associates include hemlock, elm, basswood, white pine, white brich, and red maple.)

Aspen/birch.-Forests in which aspen, balsam poplar, paper birch, or gray birch, singly or in combination, comprise a plurality of the stocking. (Common associates include maple and balsam fir.)

\section{Class of Timber}

Softwoods.-Coniferous trees that are usually evergreen, having needles or scalelike leaves.

Hardwoods.-Dicotyledonous trees that are usually broad-leaved and deciduous.

Sawtimber trees.-Live trees of commercial species that (a) are of the following minimum diameters at breast height-softwoods 9.0 inches and hardwoods 11.0 inches, and (b) contain at least one 12-foot merchantable sawlog or two noncontiguous 8-foot merchantable sawlogs and meet regional specifications for freedom from defect.

Poletimber trees.-Live trees of commercial species that meet regional specifications of soundness and form and are at least 5.0 inches dbh but are smaller than sawtimber size.

Saplings.-Live trees of commercial species that are 1.0 to 5.0 inches in diameter at breast height and of good form and vigor.

Seedlings.-Live trees of commercial species that are less than 1.0 inch in diameter at breast height and are expected to survive.

Rough and rotten trees.-See definitions under "Tree Classes".

\section{Timber Measurement and Volume}

Basal area.-The area of the cross section at breast height of a single tree, or of all the trees in a stand, usually expressed as square feet per acre.

Board foot.-A unit of lumber measurement 1 foot long, 1 foot wide, and 1 inch thick, or its equivalent. By forest-survey convention, softwoods less than 9.0 inches $\mathrm{dbh}$ and hardwoods less 
than 11.0 inches dbh do not contain board-foot volume.

Diameter at breast height (dbh).-The diameter outside bark of a standing tree measured at $4 \frac{1}{2}$ feet above the ground.

Growing-stock volume.-Net volume, in cubic feet, of live growing-stock trees that are 5.0 inches $\mathrm{dbh}$ and over, from a l-foot stump to a minimum 4.0-inch top diameter outside bark of the central stem, or to the point where the central stem breaks into limbs. Net volume equals gross volume less deduction for cull.

International 1/4-inch rule.-A log rule or formula for estimating the board-foot volume of logs. Stated mathematically, the formula is $\left[\left(\mathrm{D}^{2} \times 0.22\right)-0.71 \mathrm{D}\right] \times 0.904762$ for 4 -foot sections, where $\mathrm{D}$ is the diameter inside bark at the small end of the 4-foot section. The International $1 / 4$ inch rule is used as the USDA Forest Service standard $\log$ rule in the northeastern United States.

Standard cord.-A unit of measure for stacked bolts of wood, encompassing 128 cubic feet of wood, bark, and air space. Cord estimates can be derived from cubic-foot estimates of growing stock by applying an average factor of 80 cubic feet of wood (inside bark) per rough cord.

Sawtimber volume.-Net volume in board feet, International $1 / 4$-inch rule, of merchantable sawlogs in live sawtimber trees. Net volume equals gross volume less deductions for rot, sweep, and other defects that affect use for lumber.

Sawlog.-A log that meets minimum standards of diameter, length, and defect, including logs at least 8 feet long, and with a minimum diameter inside bark of 6 inches for softwoods and 8 inches for hardwoods. (See specifications under "Log Grade Classification".)

Sawlog portion.-That part of the bole of a sawtimber tree between the stump and the sawlog top (merchantable height).

Sawlog top.-The point on the bole of a sawtimber tree above which a sawlog cannot be produced. The minimum sawlog top is 7.0 inches d.o.b. for softwoods and 9.0 inches d.o.b. for hardwoods.

Upper-stem portion.-That part of the main stem or fork of a sawtimber tree above the saw$\log$ top to a diameter of 4.0 inches outside bark or to the point where the main stem or fork breaks into limbs.

\section{Log-Grade Classification}

Log grades are a classification of logs based on external characteristics as indicators of quality or value. The log-grade standards and grading systems for softwood and hardwood species used in this forest survey of Vermont are shown in the following specifications.
Methods of determining scaling deduction.

(Examples based on a 16-foot log with 20-inch scaling diameter)

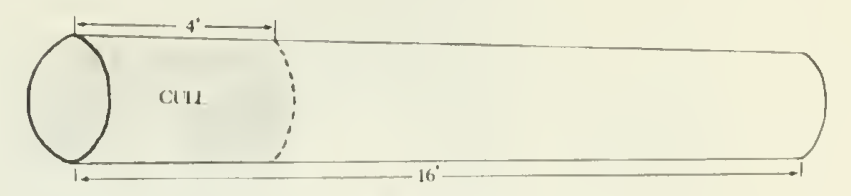

Defert section (rule 1):

Percent deduction $=\frac{4}{16}=25^{\mathrm{m}}$

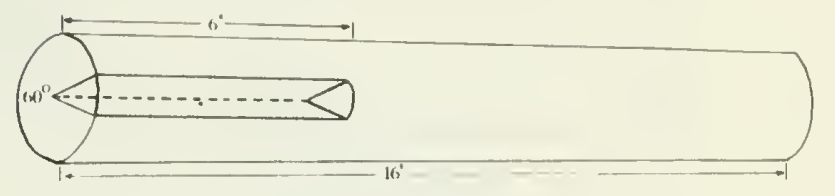

Defert sertion (rule 2):

Percent deduction $=\left(\frac{6}{16}\right)\left(\frac{60}{360}\right)=6 \cdot 1 / 4^{m}$ r

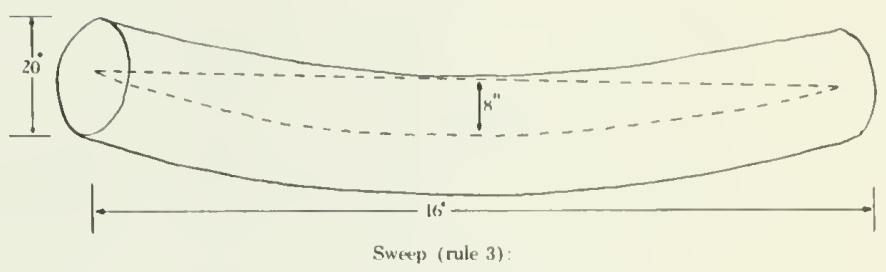

Percent deduction $=\frac{8-2}{20}=30 \%$

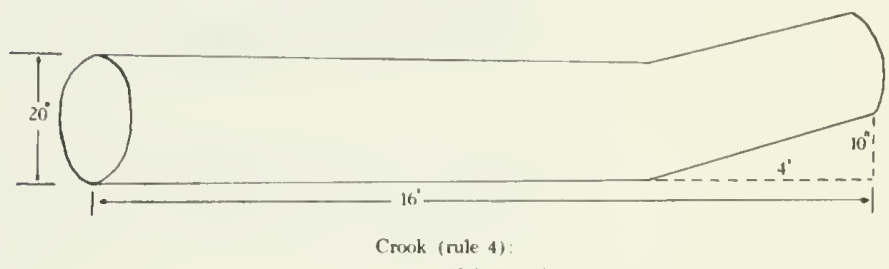

Percent deduction $=\left(\frac{10}{20}\right)\left(\frac{4}{16}\right)=12 \cdot 1 / 2 \%$

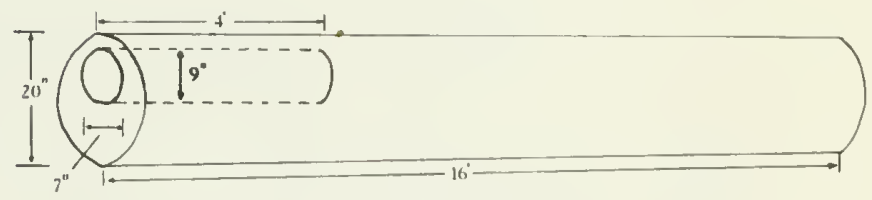

$$
\begin{aligned}
& \text { Interior defect (rule 5): } \\
& \text { Percent deduction }=\frac{(8)(10)}{(20-1)^{9}} \times \frac{4}{16}=5.5 / 9 \% \\
& \text { In practice each elipse axis can he divided by }(20-1) \\
& \text { and rounded to nearest tenth if desired. } \\
& \text { Thus } \frac{8}{19}=4, \frac{10}{19}=5 \text {, and (.4) (.5) }\left(\frac{4}{16}\right)=5 \%
\end{aligned}
$$

From: Grosenhaugh, L. R.. SHORT CUTS FOR CRtuisers And SCAl.rRS, USDA Forest Serv. South. Forest Exp. Sta., Occas. Paper 126, 1952. 
EASTERN WHITE PINE SAWLOG GRADE SPECIFICATIONS

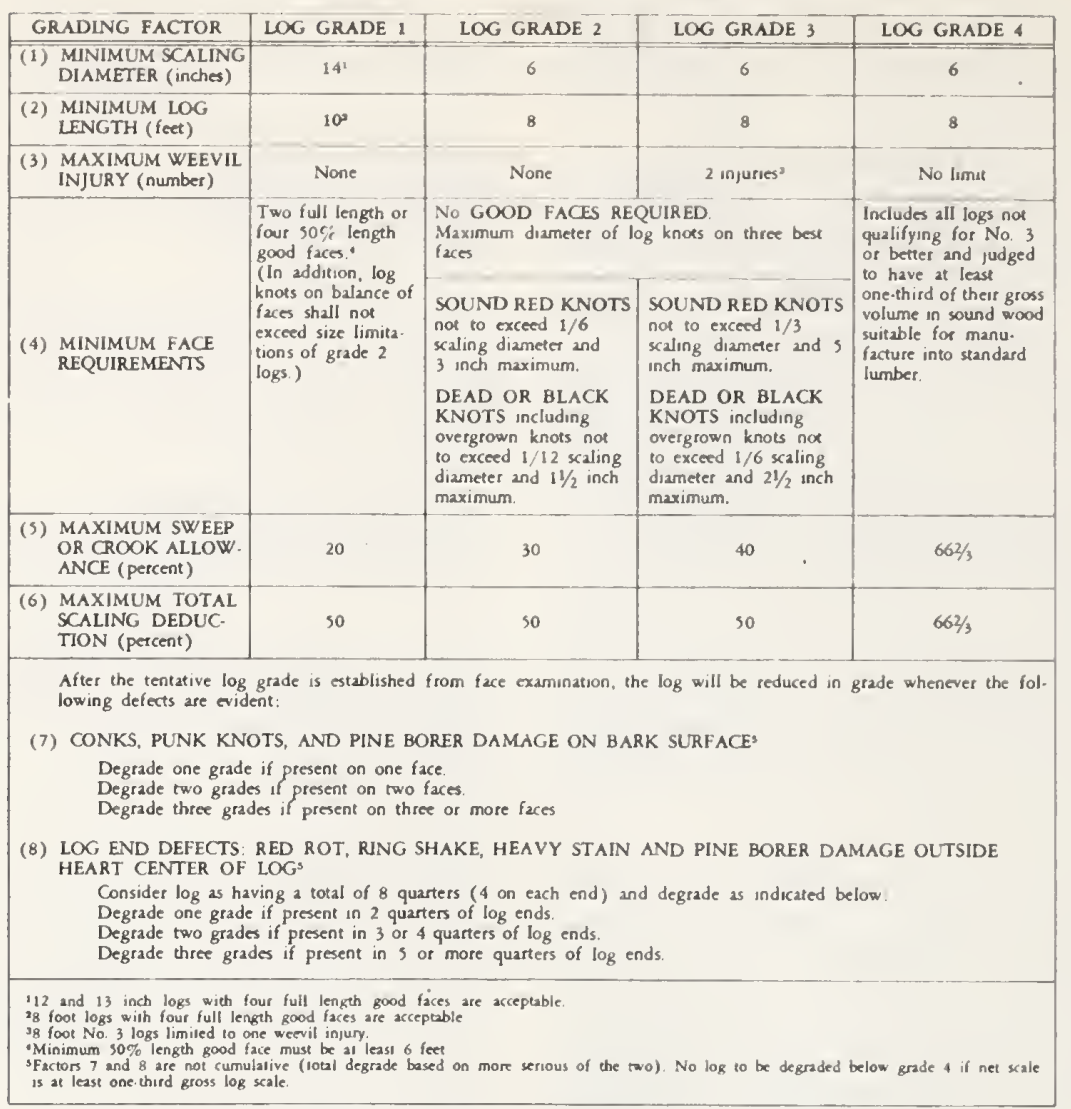

From: Ostrander, M. D., and R. L. Brisbin, Sawlog grades for eastern white pine. USDA For. Serv. Res. Pap. NE-205, 1971.

SPRUCE, FIR, HEMLOCK, TAMARACK, AND CEDAR LOG GRADE (Minimum merchantability specifications)

\begin{tabular}{|c|c|c|c|c|c|}
\hline \multirow[b]{2}{*}{$\begin{array}{l}\text { Log } \\
\text { grade }\end{array}$} & \multicolumn{2}{|c|}{ Minimum size } & \multicolumn{2}{|c|}{ Defect allowance } & \multirow[b]{2}{*}{$\begin{array}{l}\text { Other } \\
\text { requirements }\end{array}$} \\
\hline & Diameter $^{2}$ & Lengt $^{2}$ & $\begin{array}{c}\text { Sweep } \\
\text { or } \\
\text { crook }\end{array}$ & $\begin{array}{c}\text { Total } \\
\text { deduction }\end{array}$ & \\
\hline \multirow[b]{2}{*}{1} & $\begin{array}{l}\text { Inches } \\
10-12\end{array}$ & $\begin{array}{l}\text { Feet } \\
8-16 \text { in } \\
2 \text {-foot } \\
\text { multiples }\end{array}$ & $\begin{array}{l}\text { Percent } \\
25\end{array}$ & $\begin{array}{l}\text { Percent } \\
50\end{array}$ & $\begin{array}{l}\text { Sound knots not over } 2 \text { inches } \\
\text { in diameter permitted. Shake } \\
\text { permitted up to } 20 \text { percent of } \\
\text { gross scale if not combined } \\
\text { with other serious defects. }\end{array}$ \\
\hline & $13+$ & $\begin{array}{l}8-16 \text { in } \\
2 \text {-foot } \\
\text { multiples }\end{array}$ & 25 & 50 & $\begin{array}{l}\text { Sound knots not over } 3 \text { inches } \\
\text { in diameter permitted. Shake } \\
\text { permitted up to } 20 \text { percent of } \\
\text { gross scale if not combined } \\
\text { with other serious defects. }\end{array}$ \\
\hline
\end{tabular}

${ }^{1}$ At small end of log.

${ }^{2}$ Without trim. 


\section{Forest Service standard grades for hardwood factory}

lumber logs.

\begin{tabular}{|c|c|c|c|c|c|c|c|c|c|}
\hline \multirow{2}{*}{\multicolumn{2}{|c|}{ Grading Factors }} & \multicolumn{8}{|c|}{ Log grades } \\
\hline & & \multicolumn{3}{|c|}{ F1 } & \multicolumn{4}{|c|}{$\mathrm{F} 2$} & \multirow{2}{*}{\begin{tabular}{|c|} 
F3 \\
Butts \& \\
uppers
\end{tabular}} \\
\hline \multicolumn{2}{|l|}{ Position in tree } & $\begin{array}{l}\text { Butts } \\
\text { only }\end{array}$ & \multicolumn{2}{|c|}{$\begin{array}{l}\text { Butts \& } \\
\text { uppers }\end{array}$} & \multicolumn{4}{|c|}{ Butts \& uppers } & \\
\hline \multirow{2}{*}{\multicolumn{2}{|c|}{$\begin{array}{l}\text { Scaling diameter, inches } \\
\text { Length without trim, feet }\end{array}$}} & $13-15^{b}$ & $16-19$ & $20+$ & $11+^{c}$ & \multicolumn{3}{|c|}{$12+$} & $8+$ \\
\hline & & & $10+$ & & $10+$ & $8-9$ & $10-11$ & $12+$ & $8+$ \\
\hline \multirow{3}{*}{$\begin{array}{l}\text { Required } \\
\text { clear cuttings } \\
\text { of each of } 3 \\
\text { best faces }\end{array}$} & Min. length, feet & 7 & 5 & 3 & 3 & 3 & 3 & 3 & 2 \\
\hline & Max. number & 2 & 2 & 2 & 2 & 2 & 2 & 3 & $\begin{array}{c}\text { No } \\
\text { limit }\end{array}$ \\
\hline & $\begin{array}{l}\text { Min. proportion } \\
\text { of log length } \\
\text { required in clear } \\
\text { cutting }\end{array}$ & $5 / 6$ & $5 / 6$ & $5 / 6$ & $2 / 3$ & $3 / 4$ & $2 / 3$ & $2 / 3$ & $1 / 2$ \\
\hline \multirow[t]{2}{*}{$\begin{array}{l}\text { Maximum } \\
\text { sweep \& crook } \\
\text { allowance }\end{array}$} & $\begin{array}{l}\text { For logs with } \\
\text { less than } 1 / 4 \text { of } \\
\text { end in sound } \\
\text { defects }\end{array}$ & \multicolumn{3}{|c|}{$15 \%$} & \multicolumn{4}{|c|}{$30 \%$} & $50 \%$ \\
\hline & $\begin{array}{l}\text { For logs with } \\
\text { more than } 1 / 4 \text { of } \\
\text { end in sound } \\
\text { defects }\end{array}$ & \multicolumn{3}{|c|}{$10 \%$} & \multicolumn{4}{|c|}{$20 \%$} & $35 \%$ \\
\hline \multicolumn{2}{|c|}{ Maximum scaling deduction } & \multicolumn{3}{|c|}{$40 \% \mathrm{f}$} & \multicolumn{4}{|c|}{$50 \% \mathrm{~g}$} & $50 \%$ \\
\hline
\end{tabular}

End defects, although not visible in standing trees, are important in grading cut logs. Instructions for dealing with this factor are contained in Forest Prod. Lab. Rpt. D 1737.

"From USDA Forest Service Research Paper FPL-63 (13).

"Ash and basswood butts can be 12 inches if they otherwise meet requirements for small \#1's.

'Ten-inch logs of all species can be \#2 if they otherwise meet requirements for small \# I's.

"A clear cutting is a portion of a face, extending the width of the face, that is free of defects.

A face is $1 / 4$ of the surface of the log as divided leng thwise.

Otherwise \#1 logs with 41-60\% deductions can be \#2.

"Otherwise \#2 logs with 51-60\% deductions can be \#3. 
Forest Service standard specifications for hardwood construction logs."

\begin{tabular}{|c|c|c|}
\hline \multicolumn{2}{|c|}{ Position in tree } & Butt \& upper \\
\hline \multicolumn{2}{|c|}{ Min. diameter, small end } & 8 inches + \\
\hline \multicolumn{2}{|c|}{ Min. length, without trim } & 8 feet \\
\hline \multicolumn{2}{|c|}{ Clear cuttings } & No requirements. \\
\hline \multicolumn{2}{|c|}{ Sweep allowance, absolute } & $\begin{array}{l}1 / 4 \text { diameter small end for each } 8 \text { feet of } \\
\text { length. }\end{array}$ \\
\hline \multirow{3}{*}{$\begin{array}{l}\text { Sound } \\
\text { surface } \\
\text { defects }\end{array}$} & Single knots & $\begin{array}{l}\text { Any number, if no one knot has an aver- } \\
\text { age diameter above the callus in excess } \\
\text { of } 1 / 3 \text { of log diameter at point of occur- } \\
\text { rence. }\end{array}$ \\
\hline & Whorled knots & $\begin{array}{l}\text { Any number if sum of knot diameters } \\
\text { above the callus does not exceed } 1 / 3 \text { of } \\
\text { log diameter at point of occurrence. }\end{array}$ \\
\hline & Holes & $\begin{array}{l}\text { Any number provided none has a diam- } \\
\text { eter over } 1 / 3 \text { of log diameter at point of } \\
\text { occurrence, and none extends over } 3 \\
\text { inches into included timber. }{ }^{.}\end{array}$ \\
\hline \multicolumn{2}{|c|}{ Unsound surface defects } & $\begin{array}{l}\text { Same requirements as for sound defects } \\
\text { if they extend into included timber. } \\
\text { No limit if they do not. }\end{array}$ \\
\hline \multirow[b]{2}{*}{$\begin{array}{l}\text { End } \\
\text { defects }\end{array}$} & Sound & No requirements. \\
\hline & Unsound & $\begin{array}{l}\text { None allowed; log must be sound in- } \\
\text { ternally, but will admit } 1 \text { shake not to } \\
\text { exceed } 1 / 4 \text { the scaling diameter and a } \\
\text { longitudinal split not extending over } 5 \\
\text { inches into the contained timber. }\end{array}$ \\
\hline
\end{tabular}

a These specifications are minimum for the class. If, from a group of logs, factory logs are selected first, thus leaving only non-factory logs from which to select construction logs, then the quality range of the construction logs so selected is limited, and the class may be considered a grade. If selection for construction logs is given first priority, then it may be necessary to subdivide the class into grades.

' Included timber is always square, and dimension is judged from small end.

From: Rast, E. D., D. L. Sonderman, and G. L. Gammon, A gutde to hardwood log grading (REvised) USDA For. Serv. Gen. Tech. Rep. NE-1, 1973.

\section{Annual Net Growth and Timber Removals}

Average annual net growth of growing stock.The change (resulting from natural causes) in volume of sound wood in sawtimber and poletimber trees during the period between surveys, divided by the length of the period. (Components of annual net growth of growing stock include the increment in net volume of trees present at the beginning of the period and surviving to its end, plus net volume of trees reaching poletimber size during the period, minus the net volume of trees that died during the period, minus the net volume of trees that became rough or rotten trees during the period-cull increment.)
Average annual ingrowth of growing stock.The net cubic-foot volume of trees now classed as growing stock that were less than 5.0 inches $\mathrm{dbh}$ on the initial survey, divided by the length of the period between surveys.

Average annual mortality of growing stock.The net cubic-foot volume removed from the growing stock because of death from natural causes during the period between surveys, divided by the length of the period between surveys.

Average annual growing-stock removals.-The net cubic-foot volume of growing-stock trees harvested or killed in logging, cultural operations such as timber-stand improvement, land-clear- 
ing, or changes in land use during the period between surveys, converted to an annual basis.

Average annual net growth of sawtimber.The change (resulting from natural cuases) in net board-foot volume of sawtimber during the period between surveys, divided by the length of the period. (Components of annual net growth of sawtimber include the increment in net volume of sawtimber trees present at the beginning of the period and surviving to its end, plus the net volume of trees reaching sawtimber size during the period, minus the net volume of sawtimber trees that died during the period, minus the net volume of sawtimber trees that became rough or rotten trees during the period between surveys-cull increment.)

Average annual ingrowth of sawtimber.-The net board-foot volume of trees now classed as sawtimber that were not tallied as such on the initial survey, divided by the length of the period between surveys.

Average annual mortality of sawtimber.-The net board-foot volume removed from live sawtimber by death from natural causes during the period between surveys, divided by the length of the period between surveys.

Average annual sawtimber removals.-The net board-foot volume of sawtimber trees harvested or killed in logging, cultural operations such as timber-stand improvement, land-clearing, or changes in land use during the period between surveys, converted to an annual basis.

Cull increment.-The net volume of growing. stock trees on the initial inventory that became rough or rotten trees in the second inventory.

Logging residues.-The unused growing-stock volume of trees cut for products and the total growing-stock of trees destroyed in the course of logging but not removed for products.

Other removals. - The growing-stock volume of trees that were removed from the inventory and not used for products in cultural operations (weeding, thinning, etc.), land-clearing, and reclassification of some commercial forest land as noncommercial forest land.

Plant byproducts.-Wood products, such as slabs, edgings, and veneer cores, that are obtained incidental to the production of timber products and are utilized in the manufacture of other timber products. (Bark is not included.)

Plant residues.-Wood material produced incidental to the production of timber products but not utilized.

Roundwood products.-Logs, bolts, or other round sections cut from growing stock or nongrowing stock for industrial or nonindustrial uses.

Timber products.-Roundwood products and plant byproducts from all sources.

Timber removals. - The growing-stock volume of trees removed from the inventory for roundwood products, plus logging residues and other removals.

Annual net growth trend-level.-The estimated growth of growing stock or sawtimber for a specific year that is consistent with the average annual growth during the period be- tween surveys and with the current inventory (1972 for Vermont).

\section{Forest-Survey Methods}

The Northeastern Forest Experiment Station Resources Evaluation unit used a modification of the Sampling with Partial Replacement inventory design for this re-inventory of Vermont's timber resources. This inventory was based primarily on the remeasurement of plots measured in the 1966 inventory, some of which were installed in 1948. These plots, a total of 959, are a subsample of the 11,250 photo plots interpreted as part of the 1948 survey or of the 10,250 interpreted as part of the 1966 survey. This included 260 circular 1/5-acre ground plots that were originally installed in the initial forest survey of 1948. There were 70 such plots on the Green Mountain National Forest that were remeasured by National Forest personnel. The remaining 190 plots, distributed throughout the State, were measured by Resource Evaluation personnel.

A total of 699 ten-point prism plots also were measured. The plots, which were installed in 1966 as a subsample of the 10,250 photo plots, consist of a cluster of 10 prism points systematically distributed over 1 acre. At each point trees were selected for measurement by using a prism with a basal-area factor of 37.5. Area-attribute data were also tallied at each of the 10 points.

All the plots were reconciled by the field crew at the plot. By accounting for each tree at both inventory occasions (reconciling) it is possible to develop estimates of ingrowth, accretion, cull increment, mortality, and timber removals. These estimates are needed to adequately assess changes in the inventory.

\section{Geographic Sampling Units}

In the third survey of Vermont's timber resources, the State was divided into five geographic sampling units. These are identical to the sampling units used in the second forest survey. These units are:

The Northern Unit, including the counties of:

Caledonia

Essex

Franklin

Grand Isle

Lamoille

Orange

Orleans

Washington

The Southern Unit, including the counties of:

Addison

Bennington

Chittenden

Rutland

Windham

Windsor

State Forest Lands in the Northern Unit State Forest Lands in the Southern Unit The Green Mountain National Forest 
Each geographic sampling unit was treated as a separate and independent inventory. Thus the final estimates presented here for the State of Vermont are the summation of these five separate inventories.

\section{Other Lands}

All forest land other than that in National or State Forests was re-inventoried by Resources Evaluation personnel. The field personnel remeasured all the plots, 1/5-acre and 10-point, that had been measured in 1965 . They precisely relocated the plot centers, tallied all sample trees, and reconciled their tally with that for 1965.

Estimates of current volume and area were developed by using the remeasured 10-point plots. Current means for each 1965 photo strata were calculated and expanded by the 1965 photo estimates of area.

Estimates of change, growth, mortality, removals, etc., were developed from all the remeasured plots. Independent estimates of these attributes were first developed for the $1 / 5$-acre sample and the 10 -point sample. These were then weighted by the reciprocal of their variance and combined to provide estimates of totals. These totals were prorated into various breakdowns, using the tree data from the remeasured 1/5-acre plots.

\section{State Forest Lands}

Vermont Department of Forests and Parks foresters gathered the sample data for forest lands. These crews were trained by Resources Evaluation personnel and used the same procedures as Resources Evaluation personnel.

Most of the remeasured field plots on State Forest lands were 10-point prism plots. However, additions to the area of the State Forest system necessitated the selection of more samples from the 1965 photo base. These 10 -point prism plots were located and tallied in the field by standard procedures. The data from the new and remeasured 10-point prism plots were combined by photo class to develop estimates of current area and volume statistics for the State Forest lands.

\section{National Forest}

National Forest inventory crews remeasured $701 / 5$-acre plots as part of the regular management-plan inventory procedure. In addition to these remeasured plots, this inventory consisted of detailed compartment examination on about 15 percent of the forest area. Data on growth, mortality, and removals were obtained from the remeasured sample. The remeasured plots were also a source of current volume statistics. All area data for the forest were obtained from the detailed compartment examinations.

\section{County Data}

Many users of Resources Evaluation data have shown a need for county information. To provide such information, within the framework of the survey design, tables for counties have been developed, based on a survey-unit partitioning technique.

First, the geographic stratum means and variances for the various photo-plot strata were applied to the photo-plot data for each county within the stratum. This yielded an estimate of total volume or total commercial forest-land area for each county. Next, the data from all the new ground plots in each geographic stratum were used to partition the county totals into their various components. For example, if a table of cubic-foot volume by softwoods and hardwoods is to be made for a county, the estimate of total cubic-foot volume for that county is partitioned into softwood and hardwood totals according to the proportion of softweods and hardwoods for all new Resources Evaluation ground plots within the geographic stratum.

\section{Comparisons Between Inventories}

After inventories have been completed for several points in time, it is desirable to evaluate the trends between the several inventories and to make comparisons. A comparison of the 1948, 1965 , and the 1973 Resources Evaluation estimates of volume, growth, removals, and mortality was made for Vermont. A computer program, TRAS (Timber Resource Analysis System) was used.

Because of changes in procedures and in definitions, it was necessary to adjust the 1948 and 1965 inventory-volume estimates to what they would have been had the 1973 procedures and definitions been used in the 1948 and 1965 inventories. This process involves several calculations and adjustments of the 1948 and 1965 inventories in order to make them comparable with the 1973 inventory. An important step in this process is to recalculate the 1948 and 1965 inventory volume, using the average net volume per tree developed by the third inventory (1973). To do this, the average net volume per tree (for softwoods and hardwoods) developed from the third survey for each 2-inch diameter class was multiplied by the number of trees in each 2 -inch diameter class from the 1948 and 1965 inventories. These calculations resulted in inventory estimates for 1948 and 1965 adjusted to 1973 standards and procedures. These adjusted estimates, not the estimates published in the reports of the earlier surveys, are the basis for comparisons between surveys shown in this report.

\section{Data Processing}

Field-tally data consisting of plot and individual-tree information were processed and compiled into various tables using FINSYS-Forest Inventory System-on modern, large-capacity, high-speed computers.

FINSYS is a data-processing system consisting primarily of a series of computer programs that 
was developed by the Northeastern Forest Experiment Station to process and compile a large volume of forest-inventory data. The system consists of an editing subsystem that edits fieldtally data for errors; a table-compiling subsystem that compiles tables from edited field data; and finally, an output subsystem that expands the plot data to geographic-unit or statewide estimates and prints the final tables.

(FINSYS was described in a series of research papers by R. W. Wilson and R. C. Peters in 1967: The Northeastern Forest Inventory Data Processing System, USDA Forest Service Research Papers NE-61 and NE-70 to 80.)

Before modern computers came into use, the compiling of forest inventory data was a major bottleneck in forest-inventory work. Using FINSYS, it is possible, as in the case of the resurvey of Vermont, to have preliminary estimates available within 6 months after the last plot is taken. To process and compile data for a state the size of Vermont, from key-punching to the output of tables, requires about $2^{1 / 2}$ months of elapsed time and about $2 \frac{1}{2}$ hours of computer time.

FINSYS has several features that make it unique. One of these is the ability not only to calculate inventory estimates but also to calculate the variance and sampling error for each estimate. This feature provides the user with a measure of the reliability of each statistic and the ability to determine the reliability of a new estimate based upon any data combination he may make.

Another feature of FINSYS is its flexibility. The system is not restricted to the Northeastern forest survey but can be used for any large-scale forest inventory. Also, the system does not produce a standard set of tables. The individual user specifies the tables to be developed according to his particular need. Thus, at any stage in the data-processing phase or even at a later date, a specific table can be developed with minimum effort.

\section{RELIABILITY OF THE ESTIMATES}

The forest-area and timber-volume data presented in this report were based upon a carefully designed sample of forest conditions throughout Vermont. However, since neither every acre nor every tree in the State was measured, the data presented in this report are estimates. A measure of the reliability of these estimates is given by a sampling error. An associated sampling error was calculated for each estimate in this report. Many of these appear in the data tables.

Briefly, this is how the sampling error indicates the reliability of an estimate. The estimate of the total growing-stock volume in Vermont $-4,730$ million cubic feet-has an associated sampling error of 2 percent (95 million cubic feet). This means that the best estimate of the total growing-stock volume in Vermont in 1973 is 4,730 million cubic feet. If there are no errors in procedure, the odds are 2 to 1 that, if we repeated the survey in the same way, the resulting estimate of growing-stock volume would be between 4,635 million and 4,825 million cubic feet $(4,730$ \pm 95 ). Similarly, the odds are 19 to 1 that it would be within \pm 190 million cubic feet and 300 to 1 that it would be within \pm 285 million cubic feet.

The computed sampling error is not a complete measure of reliability. There are other sources of error that this term does not include. There could be imperfections in volume tables and equations, and errors in field measurement. Procedural errors were kept to a minimum by careful training of all personnel, frequent inspection of field work, and application of the most reliable survey methods.

Computed sampling errors for the totals shown in the statistical tables for Vermont:

Sampling error (percent)

Commercial forest area: $4,429.9$ thousand acres

Growing-stock volume: 4,730.2 million cubic feet

Sawtimber volume: $9,720.7$ million board feet

Annual net growth: 106.6 million cubic feet

Annual removals: 47.8 million cubic feet 


\section{COMMERCIAL TREE SPECIES OF VERMONT}

Occurrence ${ }^{l}$ Common Name

\section{Softwoods}

$\begin{array}{ll}\text { vc } & \begin{array}{l}\text { Balsam fir } \\ \text { Eastern redcedar } \\ \text { vr }\end{array} \\ \text { r } & \begin{array}{l}\text { Tamain) } \\ \text { hackmatack (larch, }\end{array} \\ \text { r } & \text { Norway spruce } \\ \text { c } & \text { White spruce } \\ \text { c } & \text { Black spruce } \\ \text { vc } & \text { Red spruce } \\ \text { r } & \text { Red pine } \\ \text { c } & \text { Pitch pine } \\ \text { c } & \text { Eastern white pine } \\ \text { vr } & \text { Scotch pine } \\ \text { r } & \text { Douglas-fir } \\ \text { c } & \text { Northern white-cedar } \\ \text { vc } & \text { Eastern hemlock }\end{array}$

\section{Hardwoods}

vc Red maple

c Silver maple

vc Sugar maple

vc Yellow birch

c Sweet birch (black)

r River birch (red)

c Paper birch (white)

r American hornbeam

(blue beech)

r Hickory

vc American beech

c White ash

r Black ash (brown)

r Green ash (red)

r Butternut

vr Black walnut

vr Black tupelo (blackgum)

c Eastern hophorn beam (ironwood)

vr American sycamore (buttonwood)

Balsam poplar

(balm-of-Gilead)

Eastern cottonwood

Bigtooth aspen (popple)

Quaking aspen (popple)

Pin cherry

Black cherry

White oak

Chestnut oak

Northern red oak

Black oak

Black willow

American basswood

American elm (white)

Slippery elm

Rock elm
Scientific Name ${ }^{2}$

Abies balsamea

Juniperus virginiana

Larix laricina

Picea abies

$P$. glauca

P. mariana

P. rubens

Pinus resinosa

$P$. rigida

P. strobus

$P$. sylvestris

Pseudotsuga menziesii

Thuja occidentalis

Tsuga canadensis

Acer rubrum

A. saccharinum

A. saccharum

Betula alleghaniensis

$B$. lenta

B. nigra

B. papyrifera

Carpinus caroliniana

Carya spp.

Fagus grandifolia

Fraxinus americana

F. nigra

$F$. pennsylvanica

Juglans cinerea

J. nigra

Nyssa silvatica

Ostrya virginiana

\section{Platanus occidentalis}

Populus balsamifera

$P$. deltoides

$P$. grandidentata

$P$. tremuloides

Prunus pensylvanica

$P$. serotina

Quercus alba

Q. prinus

Q. rubra

Q. velutina

Salix nigra

Tilia americana

Ulmus americana

U. rubra

U. thomasii

${ }^{1}$ Occurrence is based on the frequency at which the species was encountered on Resources Evaluation field plots: vr-very rare, $\mathrm{r}$-rare, c-common, and vc-very common.

${ }^{2}$ Names according to Little, Elbert L., Jr., Checklist of native and naturalized trees of the United States (including Alaska). U.S. Dep. Agric. Handb. 41, 472 p., illus.

${ }^{3}$ Names in parentheses are other frequently used common names.

${ }^{4}$ Species introduced in Vermont. 


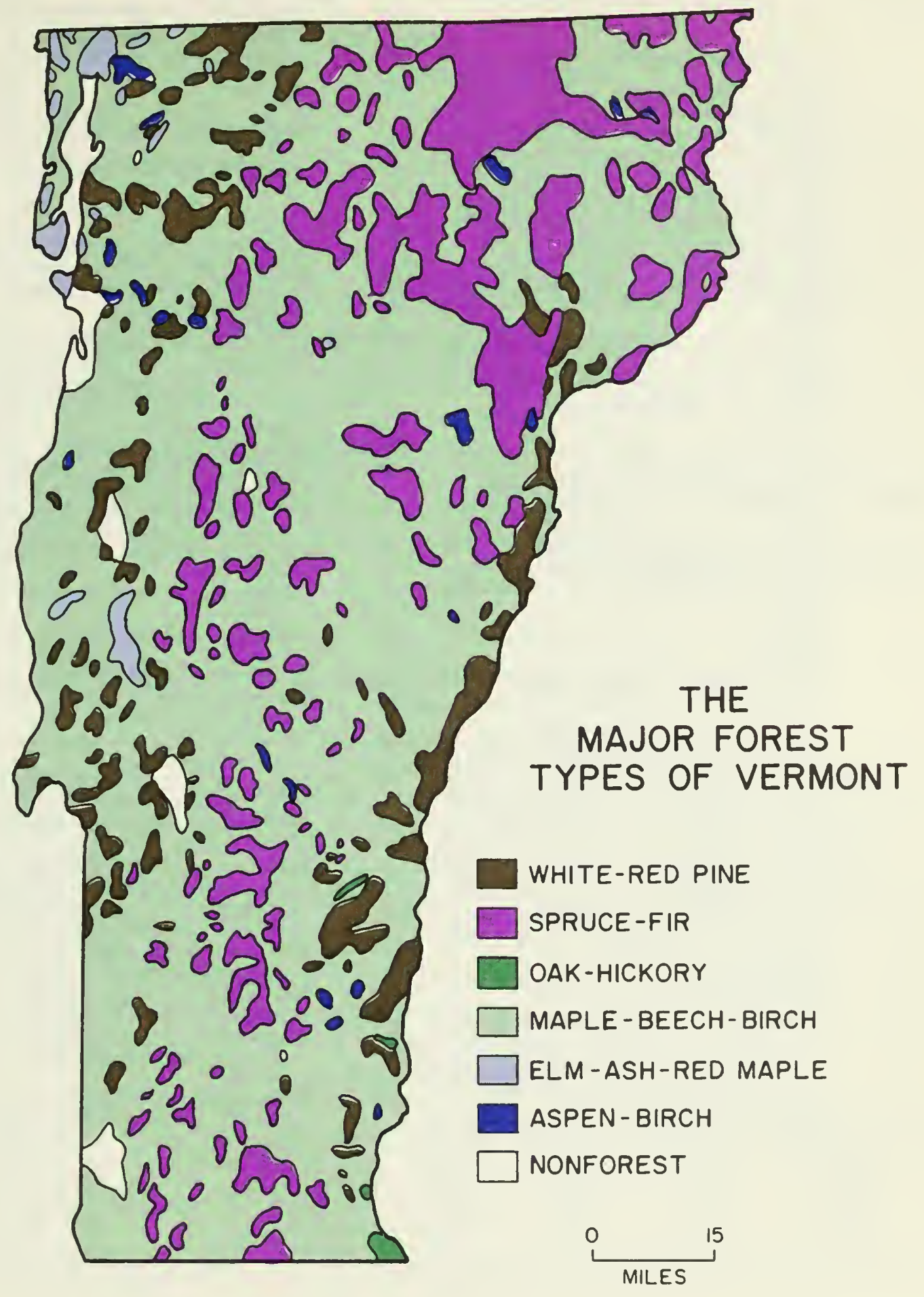


INDEX TO TABLES

\section{Statistical Tables for the State}

Table

No.

FOREST LAND

Area by land class

Ownership class

Stand-size and ownership class

Stand-volume and ownership class

Stocking class based upon components

Area-condition and ownership class

Growth-per-acre and ownership class

Forest type and ownership

Forest type and stand-size class

Major forest type and local forest type

Noncommercial forest land by forest type

Number of trees by species group, tree class, and diameter class

Number of growing-stock trees by species and diameter class

\section{TIMBER VOLUME}

Class of timber and species group

Ownership and stand size by species group

Growing stock and sawtimber by forest type and species group

Species and diameter class (growing stock)

Species and diameter class (sawtimber)

Species and standard-lumber log grades

\section{ANNUAL GROWTH} REMOVALS, AND MORTALITY

Growth, removals, and mortality of growing stock and sawtimber by species

Growth and removals of growing stock and sawtimber by ownership and species group

Mortality of growing stock and sawtimber by ownership, cause, and species group

Components of annual net growth by species group

Sampling errors for tables 1 to 22

OUTPUT OF TIMBER PRODUCTS (by softwoods and hardwoods)

Timber products by source of material Roundwood products by source
Growing stock and sawtimber removals

Unused residues by industry and type of residue

Projections of growing stock and sawtimber by species group for annual growth, cut, and inventory

\section{Statistical Tables for Geographic Units}

\section{FOREST LAND}

30

31

32

33

34
Area by county and land class

County and ownership class

County and stand-size class

Stand-volume class

Growth-per-acre class

County, and forest type

\section{TIMBER VOLUME}

Class of timber

County and tree class

Growing stock and sawtimber by ownership and species group

Growing stock and sawtimber by stand-size class and species group

Growing stock by county and standsize class

Sawtimber by county and stand-size class

Growing stock by county and forest type

Sawtimber by county and forest type

Growing stock in Northern Unit by county and species

Growing stock in Southern Unit by county and species

Sawtimber in Northern Unit by county and species

Sawtimber in Southern Unit by county and species

Growing stock in Northern Unit by species and diameter class

Growing stock in Southern Unit by species and diameter class

Sawtimber in Northern Unit by species and diameter class

Sawtimber in. Southern Unit by species and diameter class

Sawtimber in Northern Unit by species and standard-lumber log grades

Sawtimber in Southern Unit by species and standard-lumber log grades 
Table 1.- Area by land classes, Vermont, 1973

\begin{tabular}{lcr}
\hline Land class & \multicolumn{2}{c}{ Area } \\
\hline & $\begin{array}{c}\text { Thousand } \\
\text { acres }\end{array}$ & Percent \\
& & \\
Forest land: & $4,429.9$ & 75 \\
Commercial & 26.0 & 1 \\
Productive-reserved & 17.5 & (a) \\
Christmas-tree plantation & 20.3 & (a) \\
Unproductive & $4,493.7$ & 76 \\
$\quad$ Total forest land & & \\
\cline { 2 - 3 } Nonforest: & 792.1 & 13 \\
Cropland $b$ & 217.6 & 4 \\
Pasture $b$ & 432.0 & 7 \\
Other & & \\
$\quad$ Total nonforest land & $1,441.7$ & 24 \\
Total aread & $5,935.4$ & 100 \\
\hline
\end{tabular}

a Less than 0.5 percent.

bSource: 1969 and 1964 Census of Agriculture. Total cropland includes cropland used for pasture. Pasture total based upon ratios developed from the 1964 census report. Data extrapolated to 1973 .

'Includes swampland industrial and urban areas, other nonforest land, and 37,725 acres classed as water by Resources Evaluation standards but defined by the Bureau of the Census as land.

dSource: United States Bureau of the Census, Areas of Vermont: 1960 (January 1967).
Table 2. - Area of commercial forest land, by ownership classes, Vermont, 1973

\begin{tabular}{lcc}
\hline \multicolumn{1}{c}{ Ownership class } & \multicolumn{2}{c}{ Area $^{\mathrm{a}}$} \\
\hline & $\begin{array}{c}\text { Thousand } \\
\text { acres }\end{array}$ & Percent \\
& 228.6 & 5 \\
National Forest & 3.8 & $(\mathrm{~b})$ \\
Other federal & 168.2 & 4 \\
State & 41.0 & 1 \\
County and municipal & 441.6 & 10 \\
\cline { 2 - 3 } Total public & 666.3 & 15 \\
Forest industry & 19.3 & 1 \\
Farmer owned: & 589.0 & 13 \\
Corporate & 38.6 & 1 \\
$\quad$ Individual & 646.9 & 15 \\
Other & & \\
$\quad$ Total farmer owned & 173.9 & 4 \\
Miscellaneous private: & $2,346.6$ & 53 \\
$\quad$ Corporate & 154.6 & 3 \\
\hline Individual & $2,675.1$ & 60 \\
$\quad$ Other c & $4,429.9$ & 100 \\
$\quad$ Total misc. private & & \\
\cline { 2 - 3 } All ownerships & &
\end{tabular}

a Estimates of area in each private ownership class are based upon the forest-land ownership study by the Northeastern Forest Experiment Station.

$b$ Less than 0.5 percent.

c Includes acreage owned by business partnerships and organizations such as churches, Boy Scouts of America, and associations.

\section{Table 3.-Area of commercial forest land, by stand-size and ownership classes, Vermont, 1973}

[In thousands of acres]

\begin{tabular}{lccccc}
\hline Stand-size class & $\begin{array}{c}\text { All } \\
\text { ownerships }\end{array}$ & $\begin{array}{c}\text { National } \\
\text { Forest }\end{array}$ & $\begin{array}{c}\text { Other } \\
\text { public }\end{array}$ & $\begin{array}{c}\text { Forest } \\
\text { industry }\end{array}$ & $\begin{array}{c}\text { Farmer } \\
\text { and other }\end{array}$ \\
\hline Sawtimber stands & $2,061.1$ & 127.0 & 124.6 & 443.8 & $1,365.7$ \\
Poletimber stands & 954.5 & 63.9 & 41.1 & 111.7 & 737.8 \\
Sapling-seedling stands & $1,376.5$ & 37.7 & 47.3 & 110.8 & $1,180.7$ \\
Nonstocked areas & 37.8 & - & - & - & 37.8 \\
All classes & $4,429.9$ & 228.6 & 213.0 & 666.3 & $3,322.0$ \\
\hline
\end{tabular}

\section{Table 4.-Area of commercial forest land, by stand-volume and ownership classes, Vermont, 1973}

[In thousands of acres]

\begin{tabular}{cccccc}
\hline $\begin{array}{c}\text { Stand-volume } \\
\text { per acre } \\
\text { (board feet) }\end{array}$ & $\begin{array}{c}\text { All } \\
\text { ownerships }\end{array}$ & $\begin{array}{c}\text { National } \\
\text { Forest }\end{array}$ & $\begin{array}{c}\text { Other } \\
\text { public }\end{array}$ & $\begin{array}{c}\text { Forest } \\
\text { industry }\end{array}$ & $\begin{array}{c}\text { Farmer } \\
\text { and other }\end{array}$ \\
\hline Less than 1,500 & $1,552.3$ & 119.6 & 43.9 & 110.6 & $1,278.2$ \\
1,500 to 5,000 & $2,094.8$ & 101.3 & 126.1 & 442.0 & $1,425.4$ \\
More than 5,000 & 782.8 & 7.7 & 43.0 & 113.7 & 618.4 \\
All classes & $4,429.9$ & 228.6 & 213.0 & 666.3 & $3,322.0$ \\
\hline
\end{tabular}

\footnotetext{
${ }^{a}$ International 1/4-inch rule.
} 
Table 5. - Area of commercial forest land, by stocking classes based on selected stand components, Vermont, 1973

[In thousands of acres]

\begin{tabular}{|c|c|c|c|c|c|}
\hline \multirow{3}{*}{$\begin{array}{c}\text { Stocking } \\
\text { class }^{\mathrm{a}} \\
\text { (percent) }\end{array}$} & \multicolumn{5}{|c|}{ Stocking classified in terms of- } \\
\hline & \multirow{2}{*}{$\underset{\text { trees }}{\text { All }}$} & \multicolumn{3}{|c|}{ Growing-stock trees } & \multirow{2}{*}{$\begin{array}{l}\text { Rough and } \\
\text { rotten } \\
\text { trees }\end{array}$} \\
\hline & & Total & Desirable & Acceptable & \\
\hline $\begin{array}{l}160 \\
150 \text { to } 160 \\
140 \text { to } 150 \\
130 \text { to } 140\end{array}$ & $\begin{array}{r}13.2 \\
178.9 \\
598.8 \\
705.1 \\
\end{array}$ & $\begin{array}{r}\overline{8.9} \\
21.8 \\
105.6 \\
\end{array}$ & $\begin{array}{l}\text { - } \\
\text { - }\end{array}$ & $\begin{array}{r}\overline{7.8} \\
13.5 \\
38.1 \\
\end{array}$ & $\begin{array}{l}\overline{-} \\
= \\
\end{array}$ \\
\hline Overstocked & $1,496.0$ & 136.3 & - & 59.4 & - \\
\hline $\begin{array}{l}120 \text { to } 130 \\
110 \text { to } 120 \\
100 \text { to } 110\end{array}$ & $\begin{array}{l}852.0 \\
829.0 \\
446.5\end{array}$ & $\begin{array}{l}169.3 \\
293.6 \\
529.7\end{array}$ & z & $\begin{array}{l}132.9 \\
242.4 \\
470.6\end{array}$ & $\begin{array}{l}8.1 \\
9.7 \\
2.2\end{array}$ \\
\hline Fully stocked & $2,127.5$ & 992.6 & - & 845.9 & 20.0 \\
\hline $\begin{array}{l}90 \text { to } 100 \\
80 \text { to } 90 \\
70 \text { to } 80 \\
60 \text { to } 70\end{array}$ & $\begin{array}{r}198.3 \\
214.9 \\
114.7 \\
90.4 \\
\end{array}$ & $\begin{array}{l}470.8 \\
528.4 \\
584.2 \\
632.5 \\
\end{array}$ & $\begin{array}{l}\bar{z} \\
\bar{z}\end{array}$ & $\begin{array}{l}500.2 \\
498.3 \\
657.8 \\
623.3 \\
\end{array}$ & $\begin{array}{r}29.8 \\
56.3 \\
219.5 \\
281.0 \\
\end{array}$ \\
\hline Medium stocked & 618.3 & $2,215.9$ & - & $2,279.6$ & 586.6 \\
\hline $\begin{array}{l}50 \text { to } 60 \\
40 \text { to } 50 \\
30 \text { to } 40 \\
20 \text { to } 30 \\
10 \text { to } 20 \\
\text { Less than } 10\end{array}$ & $\begin{array}{r}63.7 \\
72.0 \\
42.3 \\
10.1 \\
- \\
-\end{array}$ & $\begin{array}{r}432.1 \\
365.8 \\
108.6 \\
119.1 \\
41.2 \\
18.3 \\
\end{array}$ & $\begin{array}{r}8.1 \\
9.6 \\
41.4 \\
152.1 \\
482.3 \\
3,736.4 \\
\end{array}$ & $\begin{array}{r}471.8 \\
409.0 \\
178.4 \\
118.1 \\
49.4 \\
18.3 \\
\end{array}$ & $\begin{array}{l}591.2 \\
559.0 \\
885.5 \\
883.1 \\
543.0 \\
361.5\end{array}$ \\
\hline Poorly stocked & 188.1 & $1,085.1$ & $4,429.9$ & $1,245.0$ & $3,823.3$ \\
\hline All classes & $4,429.9$ & $4,429.9$ & $4,429.9$ & $4,429.9$ & $4,429.9$ \\
\hline
\end{tabular}

${ }^{\text {a }}$ Fully stocked stands are considered to be 75 to 100 square feet of basal area.

\section{Table 6. - Area of commercial forest land, by area-condition and ownership classes, Vermont, 1973}

[In thousands of acres]

\begin{tabular}{|c|c|c|c|c|c|}
\hline $\begin{array}{l}\text { Area-condition } \\
\text { class }^{\mathrm{a}}\end{array}$ & $\begin{array}{c}\text { All } \\
\text { ownerships }\end{array}$ & $\begin{array}{c}\text { National } \\
\text { Forest }\end{array}$ & $\begin{array}{l}\text { Other } \\
\text { public }\end{array}$ & $\begin{array}{l}\text { Forest } \\
\text { industry }\end{array}$ & $\begin{array}{l}\text { Farmer } \\
\text { and other }\end{array}$ \\
\hline $\begin{array}{l}\text { Class } 10-40 \\
\text { Class } 50 \\
\text { Class } 60 \\
\text { Class } 70\end{array}$ & $\begin{array}{r}859.6 \\
2,274.8 \\
1,295.5\end{array}$ & $\begin{array}{r}29 . \overline{1} \\
124.5 \\
75.0\end{array}$ & $\begin{array}{r}34.4 \\
98.8 \\
79.8\end{array}$ & $\begin{array}{r}\overline{1} \\
150.2 \\
289.4 \\
226.7\end{array}$ & $\begin{array}{r}64 \overline{9} \\
1,762.1 \\
914.0\end{array}$ \\
\hline All classes & $4,429.9$ & 228.6 & 213.0 & 666.3 & $3,322.0$ \\
\hline
\end{tabular}

a Class 10-40.-Areas medium to fully stocked with desirable trees.

Class 50.-Areas poorly stocked with desirable trees, but fully stocked with growing-stock trees.

Class 60 .- Areas poorly stocked with desirable trees, but with medium to full stocking of growing-stock trees.

Class 70.-Areas poorly stocked with desirable trees, and poorly stocked with growing-stock trees. 
Table 7.-Area of commercial forest land, by potential site productivity and ownership classes, Vermont, 1973

[In thousands of acres]

\begin{tabular}{cccccc}
\hline $\begin{array}{c}\text { Growth-per- } \\
\text { acre class } \\
\text { (cubic feet) }\end{array}$ & $\begin{array}{c}\text { All } \\
\text { ownerships }\end{array}$ & $\begin{array}{c}\text { National } \\
\text { Forest }\end{array}$ & $\begin{array}{c}\text { Other } \\
\text { public }\end{array}$ & $\begin{array}{c}\text { Forest } \\
\text { industry }\end{array}$ & $\begin{array}{c}\text { Farmer } \\
\text { and other }\end{array}$ \\
\hline 120 to 165 & 474.5 & 10.1 & 18.4 & 53.7 & 392.3 \\
85 to 120 & 862.2 & 26.7 & 21.1 & 158.5 & 655.9 \\
50 to 85 & $1,603.3$ & 96.0 & 91.2 & 191.1 & $1,225.0$ \\
Less than 50 & $1,489.9$ & 95.8 & 82.3 & 263.0 & $1,048.8$ \\
All classes & $4,429.9$ & 228.6 & 213.0 & 666.3 & $3,322.0$ \\
\hline
\end{tabular}

Table 8.-Area of commercial forest land, by forest types and ownership classes, Vermont, 1973

[In thousands of acres]

\begin{tabular}{lcrrrr}
\hline \multicolumn{1}{c}{ Forest type } & $\begin{array}{c}\text { All } \\
\text { ownerships }\end{array}$ & $\begin{array}{c}\text { National } \\
\text { Forest }\end{array}$ & $\begin{array}{c}\text { Other } \\
\text { public }\end{array}$ & $\begin{array}{c}\text { Forest } \\
\text { industry }\end{array}$ & $\begin{array}{c}\text { Farmer } \\
\text { and other }\end{array}$ \\
\hline White and red pine & 650.1 & 2.4 & 18.8 & 25.8 & 603.1 \\
Spruce/fir & 784.4 & 18.7 & 25.7 & 97.6 & 642.4 \\
Oak/pine & 85.3 & -7 & 1.7 & - & 83.6 \\
Oak/hickory & 70.9 & 4.9 & 1.5 & - & 64.5 \\
Elm/ash/red maple & 504.9 & 5.2 & 14.1 & 9.0 & 476.6 \\
Maple/beech/birch & $2,082.4$ & 188.0 & 141.9 & 515.9 & $1,236.6$ \\
Aspen/birch & 251.9 & 9.4 & 9.3 & 18.0 & 215.2 \\
\hline All types & $4,429.9$ & 228.6 & 213.0 & 666.3 & $3,322.0$ \\
\hline
\end{tabular}

Table 9.-Area of commercial forest land, by forest types and stand-size classes, Vermont, 1973

[In thousands of acres]

\begin{tabular}{|c|c|c|c|c|c|}
\hline Forest type & $\begin{array}{c}\text { All } \\
\text { stands }\end{array}$ & $\begin{array}{l}\text { Saw- } \\
\text { timber } \\
\text { stands }\end{array}$ & $\begin{array}{l}\text { Pole- } \\
\text { timber } \\
\text { stands }\end{array}$ & $\begin{array}{l}\text { Sapling- } \\
\text { seedling } \\
\text { stands }\end{array}$ & $\begin{array}{l}\text { Nonstocked } \\
\text { areas }\end{array}$ \\
\hline $\begin{array}{l}\text { White and red pine } \\
\text { Spruce/fir } \\
\text { Oak/pine } \\
\text { Oak/hickory } \\
\text { Elm/ash/red maple } \\
\text { Maple/beech/birch } \\
\text { Aspen/birch }\end{array}$ & $\begin{array}{r}650.1 \\
784.4 \\
85.3 \\
70.9 \\
504.9 \\
2,082.4 \\
251.9\end{array}$ & $\begin{array}{r}437.7 \\
178.3 \\
30.9 \\
42.7 \\
180.5 \\
1,143.7 \\
47.2\end{array}$ & $\begin{array}{r}45.2 \\
224.1 \\
19.4 \\
28.2 \\
118.2 \\
436.2 \\
83.2\end{array}$ & $\begin{array}{r}156.9 \\
372.7 \\
35.0 \\
-\overline{1} \\
196.0 \\
502.5 \\
113.4\end{array}$ & $\begin{array}{r}10.3 \\
9.3 \\
\overline{-} \\
10.2 \\
\overline{8.1}\end{array}$ \\
\hline All types & $4,429.9$ & $2,061.0$ & 954.5 & $1,376.5$ & 37.9 \\
\hline
\end{tabular}


Table 10.-Area of commercial forest land by local forest types and major forest types. Vermont, 1973

[In thousands of acres]

\begin{tabular}{lr}
\hline \multicolumn{1}{c}{$\begin{array}{c}\text { Local forest type and } \\
\text { major forest type }\end{array}$} & Forest type \\
\hline Red pine & 20.6 \\
White pine & 355.5 \\
White pine/hemlock & 63.5 \\
Hemlock & 210.5 \\
TOTAL WHITE AND RED PINE & 650.1 \\
Balsam fir & 299.9 \\
Black spruce & 9.2 \\
Red spruce/balsam fir & 331.2 \\
Northern white-cedar & 105.6 \\
White spruce & 38.5 \\
TOTAL SPRUCE/FIR & 784.4 \\
White pine/red oak/white oak & 85.3 \\
TOTAL OAK/PINE & 85.3 \\
White oak/red oak/hickory & 17.0 \\
Northern red oak & 53.9 \\
TOTAL OAK/HICKORY & 70.9 \\
Black ash/elm/red maple & 477.4 \\
Willow & 27.5 \\
TOTAL ELM/ASH/MAPLE & 504.9 \\
Sugar maple/beech/yellow birch & $2,037.2$ \\
Black cherry & 45.2 \\
TOTAL MAPLE/BEECH/BIRCH & $2,082.4$ \\
Aspen & 101.1 \\
Paper birch & 150.8 \\
TOTAL ASPEN/BIRCH & 251.9 \\
Total all types & $4,429.9$ \\
\hline
\end{tabular}

Table 11.-Area of forest land, by forest types, Vermont, 1973

[In thousands of acres]

\begin{tabular}{lrrrr}
\hline Forest type & $\begin{array}{c}\text { All } \\
\text { areas }\end{array}$ & $\begin{array}{c}\text { Commercial } \\
\text { forest } \\
\text { land }\end{array}$ & $\begin{array}{c}\text { Productive- } \\
\text { reserved } \\
\text { areas }\end{array}$ & $\begin{array}{c}\text { Unproductive } \\
\text { areas }\end{array}$ \\
\hline White and red pine & 652.2 & 650.1 & 2.1 & - \\
Spruce/fir & 822.0 & 784.4 & 20.5 & -4 \\
Oak/pine & 85.7 & 85.3 & .4 & - \\
Oak/hickory & 71.3 & 70.9 & .4 & 1.7 \\
Elm/ash/red maple & 508.7 & 504.9 & 2.1 & - \\
Maple/beech/birch & $2,100.3$ & $2,082.4$ & 16.4 & 20.3 \\
Aspen/birch & 253.5 & 251.9 & 1.6 & \\
All types & $4,493.7$ & $4,429.9$ & 43.5 & \\
\hline
\end{tabular}


Table 12. - Number of trees on commercial forest land by species groups, tree classes, and diameter classes, Vermont, 1973

[In thousands of trees]

\begin{tabular}{|c|c|c|c|c|c|c|}
\hline \multirow{2}{*}{$\begin{array}{l}\text { Dbh class } \\
\text { (inches) }\end{array}$} & \multicolumn{3}{|c|}{ Softwoods } & \multicolumn{3}{|c|}{ Hardwoods } \\
\hline & $\begin{array}{l}\text { Growing- } \\
\text { stock trees }\end{array}$ & $\begin{array}{l}\text { Rough and } \\
\text { rotten trees }\end{array}$ & Total & $\begin{array}{l}\text { Growing- } \\
\text { stock trees }\end{array}$ & $\begin{array}{l}\text { Rough and } \\
\text { rotten trees }\end{array}$ & Total \\
\hline $\begin{array}{l}1.0 \text { to } 2.9 \\
3.0 \text { to } 4.9\end{array}$ & $\begin{array}{l}193,597 \\
160,659\end{array}$ & $\begin{array}{r}205,679 \\
78,096\end{array}$ & $\begin{array}{l}399,276 \\
238,755\end{array}$ & $\begin{array}{l}328,918 \\
220,529\end{array}$ & $\begin{array}{l}641,108 \\
245,084 \\
\end{array}$ & $\begin{array}{l}970,026 \\
465,613\end{array}$ \\
\hline Total saplings & 354,256 & 283,775 & 638,031 & 549,447 & 886,192 & $1,435,639$ \\
\hline $\begin{array}{l}5.0 \text { to } 6.9 \\
7.0 \text { to } 8.9 \\
9.0 \text { to } 10.9\end{array}$ & $\begin{array}{r}97,684 \\
59,537 \\
- \\
\end{array}$ & $\begin{array}{r}25,004 \\
11,316 \\
- \\
\end{array}$ & $\begin{array}{r}122,688 \\
70,853 \\
- \\
\end{array}$ & $\begin{array}{r}124,134 \\
91,184 \\
55,754 \\
\end{array}$ & $\begin{array}{l}79,903 \\
39,670 \\
19,984 \\
\end{array}$ & $\begin{array}{r}204,037 \\
130,854 \\
75,738 \\
\end{array}$ \\
\hline Total poletimber & 157,221 & 36,320 & 193,541 & 271,072 & 139,557 & 410,629 \\
\hline $\begin{array}{r}9.0 \text { to } 10.9 \\
11.0 \text { to } 12.9 \\
13.0 \text { to } 14.9\end{array}$ & $\begin{array}{r}31,987 \\
15,850 \\
7,770 \\
\end{array}$ & $\begin{array}{l}6,556 \\
2,988 \\
1,438\end{array}$ & $\begin{array}{r}38,543 \\
18,838 \\
9,208 \\
\end{array}$ & $\begin{array}{r}31,210 \\
16,855\end{array}$ & $\begin{array}{r}12,7 \overline{73} \\
7,939 \\
\end{array}$ & $\begin{array}{r}43, \overline{83} \\
24,794 \\
\end{array}$ \\
\hline Total small sawtimber & 55,607 & 10,982 & 66,589 & 48,065 & 20,712 & 68,777 \\
\hline $\begin{array}{l}15.0 \text { to } 16.9 \\
17.0 \text { to } 18.9 \\
19.0 \text { to } 20.9 \\
21.0 \text { to } 28.9 \\
29.0 \text { and larger }\end{array}$ & $\begin{array}{r}3,406 \\
1,491 \\
702 \\
615 \\
34 \\
\end{array}$ & $\begin{array}{r}1,044 \\
597 \\
246 \\
348 \\
43 \\
\end{array}$ & $\begin{array}{r}4,450 \\
2,088 \\
948 \\
963 \\
77\end{array}$ & $\begin{array}{r}8,104 \\
4,048 \\
1,758 \\
1,845 \\
172 \\
\end{array}$ & $\begin{array}{r}4,633 \\
2,923 \\
1,902 \\
3,141 \\
638 \\
\end{array}$ & $\begin{array}{r}12,737 \\
6,971 \\
3,660 \\
4,986 \\
810 \\
\end{array}$ \\
\hline Total large sawtimber & 6,248 & 2,278 & 8,526 & 15,927 & 13,237 & 29,164 \\
\hline All classes & 573,332 & 333,355 & 906,687 & 884,511 & $1,059,698$ & $1,944,209$ \\
\hline
\end{tabular}

Table 13.-Number of growing-stock trees on commercial forest land, by species and diameter classes, Vermont, 1973

[In thousands of trees]

\begin{tabular}{|c|c|c|c|c|c|c|c|c|c|c|c|}
\hline \multirow[b]{2}{*}{ Species } & \multirow{2}{*}{$\begin{array}{l}\text { All } \\
\text { classes }\end{array}$} & \multicolumn{10}{|c|}{ Diameter class (inches at breast height) } \\
\hline & & $\begin{array}{l}5.0 . \\
6.9\end{array}$ & & & & & & & $\begin{array}{l}19.0- \\
20.9\end{array}$ & $\begin{array}{l}21.0- \\
28.9\end{array}$ & $29.0+$ \\
\hline $\begin{array}{l}\text { White and red pine } \\
\text { Balsam fir } \\
\text { Spruce } \\
\text { Hemlock } \\
\text { Other softwoods }\end{array}$ & & $\begin{array}{l}11,605 \\
31,359 \\
29,240 \\
13,651 \\
11,829\end{array}$ & $\begin{array}{r}9,251 \\
15,985 \\
19,087 \\
10,841 \\
4,373 \\
\end{array}$ & $\begin{array}{r}5,516 \\
6,314 \\
10,470 \\
7,537 \\
2,150 \\
\end{array}$ & & $\begin{array}{r}2,091 \\
645 \\
2,320 \\
2,553 \\
161 \\
\end{array}$ & $\begin{array}{r}1,284 \\
199 \\
929 \\
930 \\
64 \\
\end{array}$ & $\begin{array}{r}757 \\
51 \\
201 \\
447 \\
35 \\
\end{array}$ & $\begin{array}{r}246 \\
125 \\
331 \\
-\end{array}$ & $\begin{array}{r}404 \\
77 \\
133 \\
1\end{array}$ & $\begin{array}{l}34 \\
= \\
=\end{array}$ \\
\hline Total softwoods & 219,076 & 97,684 & 59,537 & 31,987 & 15,850 & 7,770 & 3,406 & 1,491 & 702 & 615 & 34 \\
\hline $\begin{array}{l}\text { Select red oaks }{ }^{b} \\
\text { Yellow birch } \\
\text { Paper birch } \\
\text { Sugar maple } \\
\text { Red maple } \\
\text { Beech } \\
\text { Ash } \\
\text { Aspen } \\
\text { Black cherry } \\
\text { Other hardwoods }\end{array}$ & $\begin{array}{r}9,208 \\
37,817 \\
43,081 \\
102,996 \\
54,121 \\
23,400 \\
21,076 \\
18,429 \\
6,245 \\
18,691 \\
\end{array}$ & \begin{tabular}{r|}
2,016 \\
13,727 \\
18,663 \\
34,851 \\
21,027 \\
7,029 \\
8,788 \\
8,210 \\
2,315 \\
7,508
\end{tabular} & \begin{tabular}{r|}
2,370 \\
8,758 \\
12,852 \\
27,849 \\
14,989 \\
7,213 \\
5,600 \\
5,639 \\
1,498 \\
4,416
\end{tabular} & $\begin{aligned} 1,514 \\
6,427 \\
6,744 \\
18,294 \\
8,949 \\
3,167 \\
3,206 \\
2,788 \\
1,466 \\
3,199\end{aligned}$ & \begin{tabular}{r|}
1,190 \\
3,706 \\
2,845 \\
10,605 \\
5,078 \\
2,131 \\
2,070 \\
946 \\
531 \\
2,108
\end{tabular} & $\begin{aligned} 1,049 \\
2,373 \\
1,204 \\
5,410 \\
2,289 \\
2,123 \\
847 \\
591 \\
190 \\
779\end{aligned}$ & $\begin{array}{r}480 \\
1,516 \\
477 \\
2,754 \\
1,016 \\
900 \\
347 \\
169 \\
144 \\
301\end{array}$ & $\begin{array}{r}365 \\
654 \\
177 \\
1,574 \\
382 \\
488 \\
133 \\
54 \\
57 \\
164\end{array}$ & $\begin{array}{r}134 \\
355 \\
36 \\
689 \\
195 \\
222 \\
18 \\
16 \\
33 \\
60\end{array}$ & \begin{tabular}{r|r|}
72 & \\
266 & 83 \\
885 & 184 \\
127 & 127 \\
60 \\
16 \\
11 \\
141
\end{tabular} & $\begin{array}{l}18 \\
\frac{35}{85} \\
\frac{12}{7} \\
\frac{7}{15}\end{array}$ \\
\hline \multirow{2}{*}{$\begin{array}{l}\text { Total hardwoods } \\
\text { All species }\end{array}$} & 335,064 & 124,134 & 91,184 & 55,754 & 31,210 & 16,855 & 8,104 & 4,048 & 1,758 & 1,845 & 172 \\
\hline & 554,140 & 221,818 & 150,721 & 87,741 & 47,060 & 24,625 & 11,510 & 5,539 & 2,460 & 2,460 & 206 \\
\hline
\end{tabular}

a Includes $18,284,000$ northern white-cedar trees.

bIncludes 570,600 white oak trees. 
Table 14.-Net volume of timber on commercial forest land, by class of timber, softwoods and hardwoods, Vermont, 1973

[In millions of cubic feet]

\begin{tabular}{lrrr}
\hline Class of timber & All species & Softwoods & Hardwoods \\
\hline Sawtimber trees: & & & \\
Sawlog portion & $1,981.7$ & 852.2 & $1,129.5$ \\
Upper-stem portion & 404.3 & 121.1 & 283.2 \\
\cline { 2 - 4 } All sawtimber trees & $2,386.0$ & 973.3 & $1,412.7$ \\
Poletimber trees & $2,344.2$ & 744.7 & $1,599.5$ \\
\cline { 2 - 4 } All growing-stock trees & $4,730.2$ & $1,718.0$ & $3,012.2$ \\
\cline { 2 - 4 } Rough trees & 834.7 & 284.9 & 549.8 \\
Rotten trees & 340.0 & 27.6 & 312.4 \\
$\quad$ Total, all timber & $5,904.9$ & $2,030.5$ & $3,874.4$ \\
\hline
\end{tabular}

Table 15. - Net volume of growing stock and sawtimber on commercial forest land, by ownership classes, stand-size classes, softwoods and hardwoods, Vermont, 1973

\begin{tabular}{|c|c|c|c|c|c|c|}
\hline \multirow{2}{*}{$\begin{array}{l}\text { Ownership or } \\
\text { stand-size class }\end{array}$} & \multicolumn{3}{|c|}{$\begin{array}{c}\text { Growing stock } \\
\text { (Million cubic feet) }\end{array}$} & \multicolumn{3}{|c|}{$\begin{array}{c}\text { Sawtimber } \\
\text { (Million board feet) }^{\mathrm{a}}\end{array}$} \\
\hline & All species & Softwoods & Hardwoods & All species & Softwoods & Hardwoods \\
\hline & \multicolumn{6}{|c|}{ BY OWNERSHIP CLASSES } \\
\hline $\begin{array}{l}\text { National Forest } \\
\text { Other public } \\
\text { Forest industry } \\
\text { Farmer and other }\end{array}$ & $\begin{array}{r}201.9 \\
235.9 \\
707.1 \\
3,585.3 \\
\end{array}$ & $\begin{array}{r}40.1 \\
86.2 \\
199.6 \\
1,392.1 \\
\end{array}$ & $\begin{array}{r}161.8 \\
149.7 \\
507.5 \\
2,193.2 \\
\end{array}$ & $\begin{array}{r}431.6 \\
524.1 \\
1,554.3 \\
7,210.7 \\
\end{array}$ & $\begin{array}{r}65.2 \\
207.7 \\
450.2 \\
3,152.4 \\
\end{array}$ & $\begin{array}{r}366.4 \\
316.4 \\
1,104.1 \\
4,058.3 \\
\end{array}$ \\
\hline All ownerships & $4,730.2$ & $1,718.0$ & $3,012.2$ & $9,720.7$ & $3,875.5$ & $5,845.2$ \\
\hline . & \multicolumn{6}{|c|}{ BY STAND-SIZE CLASSES } \\
\hline $\begin{array}{l}\text { Sawtimber stands } \\
\text { Poletimber stands } \\
\text { Sapling-seedling stands } \\
\text { Nonstocked areas }\end{array}$ & $\begin{array}{r}2,813.4 \\
1,248.0 \\
664.2 \\
4.6\end{array}$ & $\begin{array}{r}1,015.5 \\
424.9 \\
273.0 \\
4.6\end{array}$ & $\begin{array}{r}1,797.9 \\
823.1 \\
391.2 \\
-\end{array}$ & $\begin{array}{r}7,151.7 \\
1,537.3 \\
1,015.9 \\
15.8\end{array}$ & $\begin{array}{r}2,788.6 \\
611.0 \\
460.1 \\
15.8\end{array}$ & $\begin{array}{r}4,363.1 \\
926.3 \\
555.8 \\
-\end{array}$ \\
\hline All classes & $4,730.2$ & $1,718.0$ & $3,012.2$ & $9,720.7$ & $3,875.5$ & $5,845.2$ \\
\hline
\end{tabular}

a International $1 / 4$-inch rule.

Table 16. - Net volume of growing stock and sawtimber on commercial forest land, by forest type, softwoods and hardwoods, Vermont, 1973

\begin{tabular}{lrrrrrrrr}
\hline \multirow{2}{*}{ Forest type } & \multicolumn{3}{c}{$\begin{array}{c}\text { Growing stock } \\
\text { (Million cubic feet) }\end{array}$} & & \multicolumn{3}{c}{$\begin{array}{c}\text { Sawtimber } \\
\text { (Million board feet) }\end{array}$} \\
\cline { 2 - 3 } \cline { 7 - 8 } & All speices & Softwoods & Hardwoods & & All species & Softwoods & Hardwoods \\
\hline White and red pine & 773.1 & 591.1 & 182.0 & & $1,863.2$ & $1,561.9$ & 301.3 \\
Spruce/fir & 832.4 & 674.5 & 157.9 & & $1,436.8$ & $1,234.4$ & 202.4 \\
Oak/pine & 81.2 & 14.1 & 67.1 & & 156.7 & 35.3 & 121.4 \\
Oak/hickory & 80.0 & 10.5 & 69.5 & & 174.2 & 16.1 & 158.1 \\
Elm/ash/red maple & 503.8 & 112.2 & & 391.6 & & 952.7 & 268.4 & 684.3 \\
Maple/beech/birch & $2,213.5$ & 262.7 & $1,950.8$ & & $4,856.5$ & 667.8 & $4,188.7$ \\
Aspen/birch & 246.2 & 52.9 & 193.3 & & 280.6 & 91.6 & 189.0 \\
All types & $4,730.2$ & $1,718.0$ & $3,012.2$ & & $9,720.7$ & $3,875.5$ & $5,845.2$ \\
\hline
\end{tabular}

\footnotetext{
${ }^{\mathrm{a}}$ International $1 / 4$-inch rule.
} 
Table 17. - Net volume of growing stock on commercial forest land, by species and diameter classes, Vermont, 1973

[In millions of cubic feet]

\begin{tabular}{|c|c|c|c|c|c|c|c|c|c|c|c|}
\hline \multirow[b]{2}{*}{ Species } & \multirow{2}{*}{$\begin{array}{c}\text { All } \\
\text { classes }\end{array}$} & \multicolumn{10}{|c|}{ Diameter class (inches at breast height) } \\
\hline & & $\begin{array}{l}5.0- \\
6.9\end{array}$ & $\begin{array}{l}7.0- \\
8.9\end{array}$ & $\begin{array}{r}9.0- \\
10.9\end{array}$ & $\begin{array}{l}11.0- \\
12.9\end{array}$ & $\begin{array}{l}13.0- \\
14.9\end{array}$ & $\begin{array}{l}15.0- \\
16.9\end{array}$ & $\begin{array}{l}17.0- \\
18.9\end{array}$ & $\begin{array}{l}19.0- \\
20.9\end{array}$ & $\begin{array}{l}21.0- \\
28.9\end{array}$ & $29.0+$ \\
\hline $\begin{array}{l}\text { White and red pine } \\
\text { Balsam fir } \\
\text { Spruce } \\
\text { Hemlock } \\
\text { Other softwoods }\end{array}$ & $\begin{array}{r}387.1 \\
337.7 \\
532.3 \\
378.6 \\
82.3 \\
\end{array}$ & $\begin{array}{r}58.4 \\
108.4 \\
117.7 \\
49.8 \\
29.2 \\
\end{array}$ & $\begin{array}{r}67.2 \\
102.3 \\
127.4 \\
64.8 \\
19.5 \\
\end{array}$ & $\begin{array}{r}59.8 \\
71.3 \\
111.1 \\
72.3 \\
16.7 \\
\end{array}$ & $\begin{array}{l}47.1 \\
33.2 \\
78.8 \\
71.8 \\
10.8 \\
\end{array}$ & $\begin{array}{r}45.8 \\
15.0 \\
52.1 \\
54.0 \\
3.3 \\
\end{array}$ & $\begin{array}{r}37.8 \\
5.8 \\
27.3 \\
26.6 \\
1.5 \\
\end{array}$ & $\begin{array}{r}28.7 \\
1.7 \\
7.6 \\
16.4 \\
1.3 \\
\end{array}$ & $\begin{array}{r}11.7 \\
5.7 \\
15.1 \\
- \\
\end{array}$ & $\begin{array}{r}27.1 \\
4.6 \\
7.8 \\
-\end{array}$ & $\begin{array}{l}3.5 \\
= \\
=\end{array}$ \\
\hline Total softwoods & $1,718.0$ & 363.5 & 381.2 & 331.2 & 241.7 & 170.2 & 99.0 & 55.7 & 32.5 & 39.5 & 3.5 \\
\hline $\begin{array}{l}\text { Select red oaks b } \\
\text { Yellow birch } \\
\text { Paper birch } \\
\text { Sugar maple } \\
\text { Red maple } \\
\text { Beech } \\
\text { Ash } \\
\text { Aspen } \\
\text { Black cherry } \\
\text { Other hardwoods }\end{array}$ & \begin{tabular}{r|}
113.1 \\
331.7 \\
282.1 \\
$1,083.2$ \\
450.3 \\
236.3 \\
181.3 \\
135.2 \\
46.5 \\
152.5
\end{tabular} & $\begin{array}{r}7.9 \\
48.2 \\
65.7 \\
137.4 \\
74.8 \\
24.3 \\
33.2 \\
28.8 \\
7.1 \\
25.0\end{array}$ & $\begin{array}{r}14.6 \\
50.7 \\
73.5 \\
189.6 \\
96.1 \\
44.1 \\
37.3 \\
37.1 \\
7.7 \\
25.8\end{array}$ & $\begin{array}{r}14.9 \\
57.5 \\
60.5 \\
201.4 \\
94.4 \\
32.3 \\
35.3 \\
31.4 \\
13.3 \\
29.6\end{array}$ & \begin{tabular}{r|}
18.1 \\
49.0 \\
38.4 \\
177.2 \\
77.6 \\
32.8 \\
35.4 \\
15.8 \\
7.3 \\
30.5
\end{tabular} & $\begin{aligned} 21.8 \\
41.8 \\
22.1 \\
127.1 \\
48.6 \\
45.0 \\
19.9 \\
13.7 \\
3.5 \\
15.9\end{aligned}$ & $\begin{array}{r}12.3 \\
36.1 \\
11.5 \\
84.7 \\
27.4 \\
24.3 \\
10.3 \\
4.8 \\
3.8 \\
8.0\end{array}$ & $\begin{array}{r}12.1 \\
19.2 \\
5.4 \\
62.5 \\
12.9 \\
17.0 \\
5.0 \\
2.1 \\
2.0 \\
6.0\end{array}$ & $\begin{array}{r}5.6 \\
12.8 \\
1.5 \\
33.8 \\
7.9 \\
9.4 \\
.9 \\
.8 \\
1.3 \\
2.7\end{array}$ & $\begin{aligned} 4.4 \\
13.4 \\
3.5 \\
59.3 \\
9.4 \\
7.1 \\
3.4 \\
.7 \\
.5 \\
7.3\end{aligned}$ & $\begin{array}{r}1.4 \\
3.0 \\
10.2 \\
1.2 \\
\frac{.6}{7} \\
\overline{1.7}\end{array}$ \\
\hline Total hardwoods & $3,012.2$ & 452.4 & 576.5 & 570.6 & 482.1 & 359.4 & 223.2 & 144.2 & 76.7 & 109.0 & 18.1 \\
\hline All species & $4,730.2$ & 815.9 & 957.7 & 901.8 & 723.8 & 529.6 & 322.2 & 199.9 & 109.2 & 148.5 & 21.6 \\
\hline
\end{tabular}

${ }^{a}$ Includes $72,200,000$ cubic feet of northern white-cedar.

b Includes $4,500,000$ cubic feet of white oak.

\section{Table 18. - Net volume of sawtimber on commercial forest land, by species and diameter classes, Vermont, 1973}

[In millions of board feet] ${ }^{a}$

\begin{tabular}{|c|c|c|c|c|c|c|c|c|c|}
\hline \multirow[b]{2}{*}{ Species } & \multirow{2}{*}{$\underset{\text { classes }}{\text { All }}$} & \multicolumn{8}{|c|}{ Diameter class (inches at breast height) } \\
\hline & & $\begin{array}{r}9.0- \\
10.9\end{array}$ & $\begin{array}{l}11.0- \\
12.9\end{array}$ & $\begin{array}{l}13.0- \\
14.9\end{array}$ & $\begin{array}{l}15.0- \\
16.9\end{array}$ & $\begin{array}{l}17.0- \\
18.9\end{array}$ & $\begin{array}{l}19.0- \\
20.9\end{array}$ & $\begin{array}{l}21.0- \\
28.9\end{array}$ & $29.0+$ \\
\hline $\begin{array}{l}\text { White and red pine } \\
\text { Balsam fir } \\
\text { Spruce } \\
\text { Hemlock } \\
\text { Other softwoods b }\end{array}$ & $\begin{array}{r}1,070.4 \\
485.3 \\
1,142.0 \\
1,050.6 \\
127.2 \\
\end{array}$ & $\begin{array}{r}202.8 \\
253.1 \\
389.0 \\
246.1 \\
58.6 \\
\end{array}$ & $\begin{array}{r}184.9 \\
132.9 \\
320.3 \\
285.5 \\
42.1 \\
\end{array}$ & $\begin{array}{r}190.2 \\
64.7 \\
223.3 \\
224.3 \\
14.2 \\
\end{array}$ & $\begin{array}{r}166.6 \\
26.4 \\
124.0 \\
117.0 \\
6.4 \\
\end{array}$ & $\begin{array}{r}127.1 \\
8.2 \\
36.5 \\
72.3 \\
5.6 \\
\end{array}$ & $\begin{array}{r}53.1 \\
27.4 \\
70.2 \\
- \\
\end{array}$ & $\begin{array}{r}128.8 \\
21.5 \\
35.2 \\
.3 \\
\end{array}$ & $\begin{array}{r}16.9 \\
= \\
=\end{array}$ \\
\hline Total softwoods & $3,875.5$ & $1,149.6$ & 965.7 & 716.7 & 440.4 & 249.7 & 150.7 & 185.8 & 16.9 \\
\hline $\begin{array}{l}\text { Select red oaks } \\
\text { Yellow birch } \\
\text { Paper birch } \\
\text { Sugar maple } \\
\text { Red maple } \\
\text { Beech } \\
\text { Ash } \\
\text { Aspen } \\
\text { Black cherry } \\
\text { Other hardwoods }\end{array}$ & $\begin{array}{r}315.0 \\
736.5 \\
333.2 \\
2,325.4 \\
744.5 \\
561.4 \\
305.6 \\
153.7 \\
74.2 \\
295.7 \\
\end{array}$ & $\begin{array}{l}= \\
= \\
= \\
= \\
= \\
=\end{array}$ & $\begin{array}{r}66.0 \\
180.8 \\
142.2 \\
660.0 \\
287.6 \\
121.3 \\
131.2 \\
58.5 \\
26.9 \\
113.1 \\
\end{array}$ & $\begin{array}{r}88.9 \\
170.2 \\
91.9 \\
518.6 \\
194.5 \\
182.7 \\
83.1 \\
57.4 \\
14.0 \\
65.0 \\
\end{array}$ & $\begin{array}{r}53.0 \\
159.3 \\
50.7 \\
366.3 \\
117.2 \\
104.9 \\
44.5 \\
21.0 \\
16.9 \\
34.5 \\
\end{array}$ & $\begin{array}{r}54.9 \\
87.6 \\
24.7 \\
284.3 \\
57.4 \\
76.2 \\
23.2 \\
9.3 \\
8.6 \\
27.6 \\
\end{array}$ & $\begin{array}{r}24.9 \\
58.7 \\
6.7 \\
154.6 \\
36.2 \\
43.1 \\
4.0 \\
4.0 \\
5.5 \\
12.3 \\
\end{array}$ & $\begin{array}{r}21.0 \\
64.8 \\
17.0 \\
289.9 \\
45.6 \\
33.2 \\
16.6 \\
3.5 \\
2.3 \\
34.7 \\
\end{array}$ & $\begin{array}{r}6.3 \\
15.1 \\
51.7 \\
6.0 \\
\overline{3.0} \\
\overline{-} \\
8.5 \\
\end{array}$ \\
\hline Total hardwoods & $5,845.2$ & - & $1,787.6$ & $1,466.3$ & 968.3 & 653.8 & 350.0 & 528.6 & 90.6 \\
\hline All species & $9,720.7$ & $1,149.6$ & $2,753.3$ & $2,183.0$ & $1,408.7$ & 903.5 & 500.7 & 714.4 & 107.5 \\
\hline
\end{tabular}

a International 1/4-inch rule.

bIncludes $95,500,000$ board feet of northern white-cedar.

cIncludes $6,700,000$ board feet of white oak. 
Table 19. - Net volume of sawtimber on commercial forest land, by species and standard-lumber log grades, Vermont, 1973

[In millions of board feet] $]^{\mathrm{a}}$

\begin{tabular}{|c|c|c|c|c|c|}
\hline \multirow{2}{*}{ Species } & \multirow{2}{*}{$\begin{array}{c}\text { All } \\
\text { classes }\end{array}$} & \multicolumn{4}{|c|}{ Standard-lumber log grades } \\
\hline & & Grade 1 & Grade 2 & Grade 3 & Grade $4^{b}$ \\
\hline $\begin{array}{l}\text { Softwoods: } \\
\text { White pine } \\
\text { Red pine } \\
\text { Other softwoods }\end{array}$ & $\begin{array}{r}995.4 \\
75.0 \\
2,805.1\end{array}$ & $\begin{array}{r}11.8 \\
3.0 \\
-\end{array}$ & $\begin{array}{r}92.2 \\
4.7 \\
-\end{array}$ & $\begin{array}{r}503.0 \\
51.0 \\
-\end{array}$ & $\begin{array}{r}388.4 \\
16.3 \\
-\end{array}$ \\
\hline Total softwoods & $3,875.5$ & 14.8 & 96.9 & 554.0 & 404.7 \\
\hline $\begin{array}{l}\text { Hardwoods: } \\
\text { Select red oaks } \\
\text { Yellow birch } \\
\text { Paper birch } \\
\text { Sugar maple } \\
\text { Red maple } \\
\text { Beech } \\
\text { Ash } \\
\text { Aspen } \\
\text { Black cherry } \\
\text { Other hardwoods }\end{array}$ & $\begin{array}{r}315.0 \\
736.5 \\
333.2 \\
2,325.4 \\
744.5 \\
561.4 \\
305.6 \\
153.7 \\
74.2 \\
295.7 \\
\end{array}$ & $\begin{array}{r}54.3 \\
71.9 \\
26.4 \\
280.4 \\
20.2 \\
11.2 \\
35.0 \\
2.7 \\
3.6 \\
22.0 \\
\end{array}$ & $\begin{array}{r}71.1 \\
190.2 \\
64.3 \\
533.9 \\
138.8 \\
81.0 \\
99.1 \\
16.1 \\
16.4 \\
48.9 \\
\end{array}$ & $\begin{array}{r}140.9 \\
402.0 \\
161.3 \\
1,100.1 \\
396.4 \\
334.3 \\
111.3 \\
93.4 \\
34.7 \\
169.6 \\
\end{array}$ & $\begin{array}{r}48.7 \\
72.4 \\
81.2 \\
411.0 \\
189.1 \\
134.9 \\
60.2 \\
41.5 \\
19.5 \\
55.2 \\
\end{array}$ \\
\hline Total hardwoods & $5,845.2$ & 527.7 & $1,259.8$ & $2,944.0$ & $1,113.7$ \\
\hline \multicolumn{6}{|c|}{ (In percent) } \\
\hline Hardwood quality & 100 & 9 & 22 & 50 & 19 \\
\hline
\end{tabular}

a International $1 / 4$-inch rule.

b Grade 4 applies only to the pines. For hardwoods the volumes in this column are for construction logs.

$c$ Softwood species other than pine are not graded.

Table 20.-Annual net growth, removals, and mortality of growing stock and sawtimber on commercial forest land, by species, Vermont, 1972

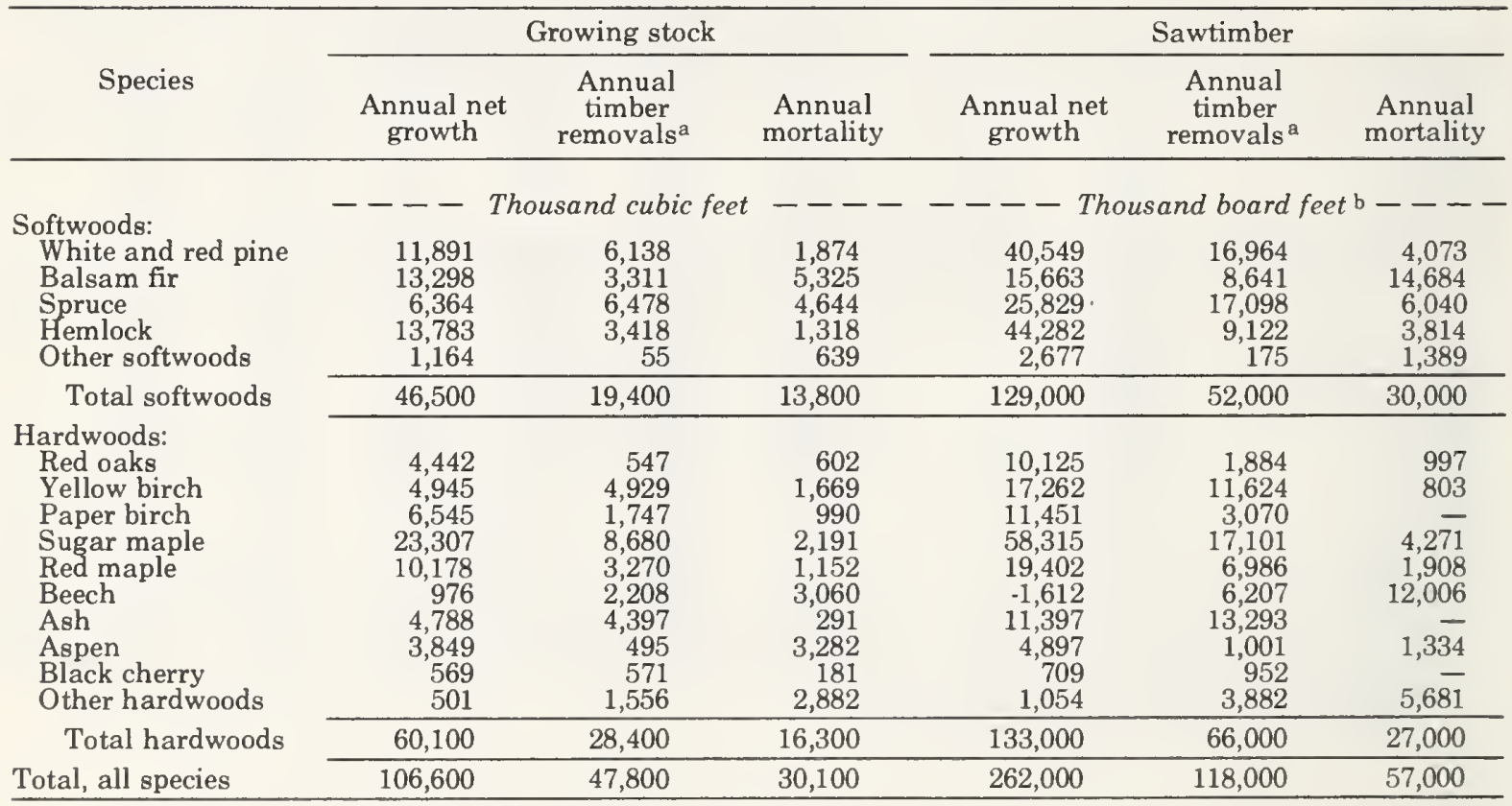

a Data for timber removals in this table are based on the trend from 1965 through 1972 and differ from those shown in table 27 . Table 27 reports results of a canvass of timber removals for 1972 .

bInternational $1 / 4-$ inch rule. 
Table 21.-Annual net growth and removals of growing stock and sawtimber on commercial forest land, by ownership classes, softwoods and hardwoods, Vermont, 1972

\begin{tabular}{|c|c|c|c|c|c|c|}
\hline Ownership & \multicolumn{3}{|c|}{ Annual net growth } & \multicolumn{3}{|c|}{ Annual timber removals ${ }^{a}$} \\
\hline & \multicolumn{6}{|c|}{$\begin{array}{l}\text { GROWING STOCK } \\
\text { Thousand cubic feet }\end{array}$} \\
\hline $\begin{array}{l}\text { National Forest } \\
\text { Other public } \\
\text { Forest industry } \\
\text { Farmer and other }\end{array}$ & $\begin{array}{r}2,623 \\
7,847 \\
21,942 \\
74,188 \\
\end{array}$ & $\begin{array}{r}568 \\
2,509 \\
7,368 \\
36,055 \\
\end{array}$ & $\begin{array}{r}2,055 \\
5,338 \\
14,574 \\
38,133 \\
\end{array}$ & $\begin{array}{r}2,064 \\
5,714 \\
21,233 \\
18,789 \\
\end{array}$ & $\begin{array}{r}402 \\
2,181 \\
9,454 \\
7,363 \\
\end{array}$ & $\begin{array}{r}1,662 \\
3,533 \\
11,779 \\
11,426 \\
\end{array}$ \\
\hline All ownerships & \multicolumn{6}{|c|}{$\begin{array}{c}\text { SAWTIMBER } \\
\text { Thousand board feet } \mathrm{b}\end{array}$} \\
\hline $\begin{array}{l}\text { National Forest } \\
\text { Other public } \\
\text { Forest industry } \\
\text { Farmer and other }\end{array}$ & $\begin{array}{r}8,520 \\
19,083 \\
56,449 \\
177,948 \\
\end{array}$ & $\begin{array}{r}1,358 \\
7,884 \\
17,711 \\
102,047 \\
\end{array}$ & $\begin{array}{r}7,162 \\
11,199 \\
38,738 \\
75,901 \\
\end{array}$ & $\begin{array}{r}12,900 \\
13,411 \\
42,657 \\
49,032 \\
\end{array}$ & $\begin{array}{r}2,326 \\
6,508 \\
16,835 \\
26,331\end{array}$ & $\begin{array}{r}10,574 \\
6,903 \\
25,822 \\
22,701 \\
\end{array}$ \\
\hline
\end{tabular}

a Data for timber removals in this table are based on the trend from 1965 through 1972 and differ from those shown in table 27. Table 27 reports results of a canvass of timber removals for 1972 .

bInternational $1 / 4$-inch rule.

Table 22.-Annual mortality of growing stock and sawtimber on commercial forest land. by ownership classes, causes, softwoods and hardwoods, Vermont, 1972

\begin{tabular}{|c|c|c|c|c|c|c|}
\hline \multirow{2}{*}{$\begin{array}{l}\text { Ownership } \\
\text { and cause }\end{array}$} & \multicolumn{3}{|c|}{$\begin{array}{c}\text { Growing stock } \\
\text { (thousand cubic feet) }\end{array}$} & \multicolumn{3}{|c|}{$\begin{array}{l}\text { Sawtimber } \\
\text { (thousand board feet) a }\end{array}$} \\
\hline & All species & Softwoods & Hardwoods & All species & Softwoods & Hardwoods \\
\hline & \multicolumn{6}{|c|}{ BY OWNERSHIP CLASS } \\
\hline $\begin{array}{l}\text { National Forest } \\
\text { Other public } \\
\text { Forest industry } \\
\text { Farmer and other }\end{array}$ & $\begin{array}{r}801 \\
2,910 \\
4,812 \\
21,577 \\
\end{array}$ & $\begin{array}{r}186 \\
2,049 \\
1,047 \\
10,518 \\
\end{array}$ & $\begin{array}{r}615 \\
861 \\
3,765 \\
11,059 \\
\end{array}$ & $\begin{array}{r}606 \\
4,047 \\
11,113 \\
41,234 \\
\end{array}$ & $\begin{array}{r}129 \\
916 \\
2,972 \\
25,983\end{array}$ & $\begin{array}{r}477 \\
3,131 \\
8,141 \\
15,251 \\
\end{array}$ \\
\hline \multirow[t]{2}{*}{ All ownerships } & 30,100 & 13,800 & 16,300 & 57,000 & 30,000 & 27,000 \\
\hline & \multicolumn{6}{|c|}{ BY CAUSE } \\
\hline $\begin{array}{l}\text { Weather } \\
\text { Insects }\end{array}$ & $\begin{array}{r}2,544 \\
211\end{array}$ & $\begin{array}{r}1,923 \\
211\end{array}$ & 621 & 1,319 & 1,319 & $=$ \\
\hline Disease & 25,706 & 10,221 & 15,485 & 54,325 & 27,325 & 27,000 \\
\hline $\begin{array}{l}\text { Other } \\
\text { Unknown }\end{array}$ & $\begin{array}{r}1,346 \\
293\end{array}$ & $\begin{array}{r}1,152 \\
293\end{array}$ & 194 & $1, \overline{55}$ & $1, \overline{356}$ & 二 \\
\hline All causes & 30,100 & 13,800 & 16,300 & 57,000 & 30,000 & 27,000 \\
\hline
\end{tabular}


Table 23.-Components of annual net growth of growing stock and sawtimber on commercial forest land, softwoods and hardwoods, Vermont, 1972

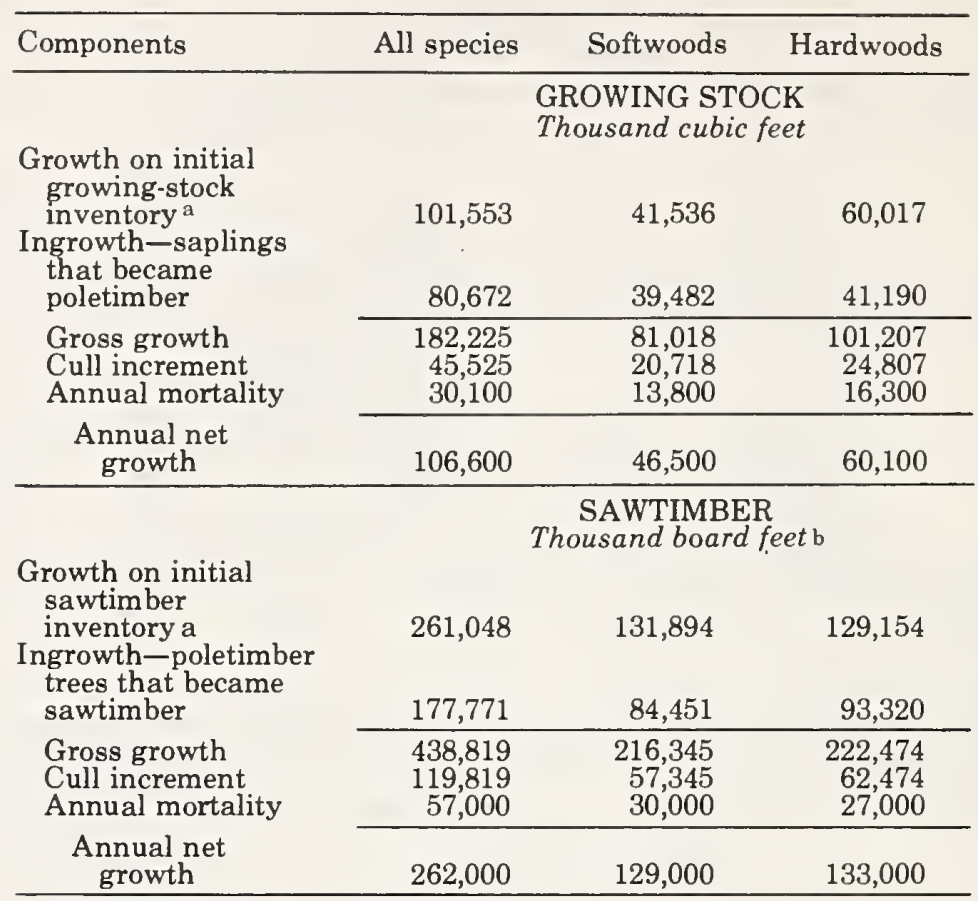

a Including growth on trees that were cut.

b International 1/4-inch rule. 
Table 24.-Sampling errors for major forest-area and timber-volume classes in Vermont,1973

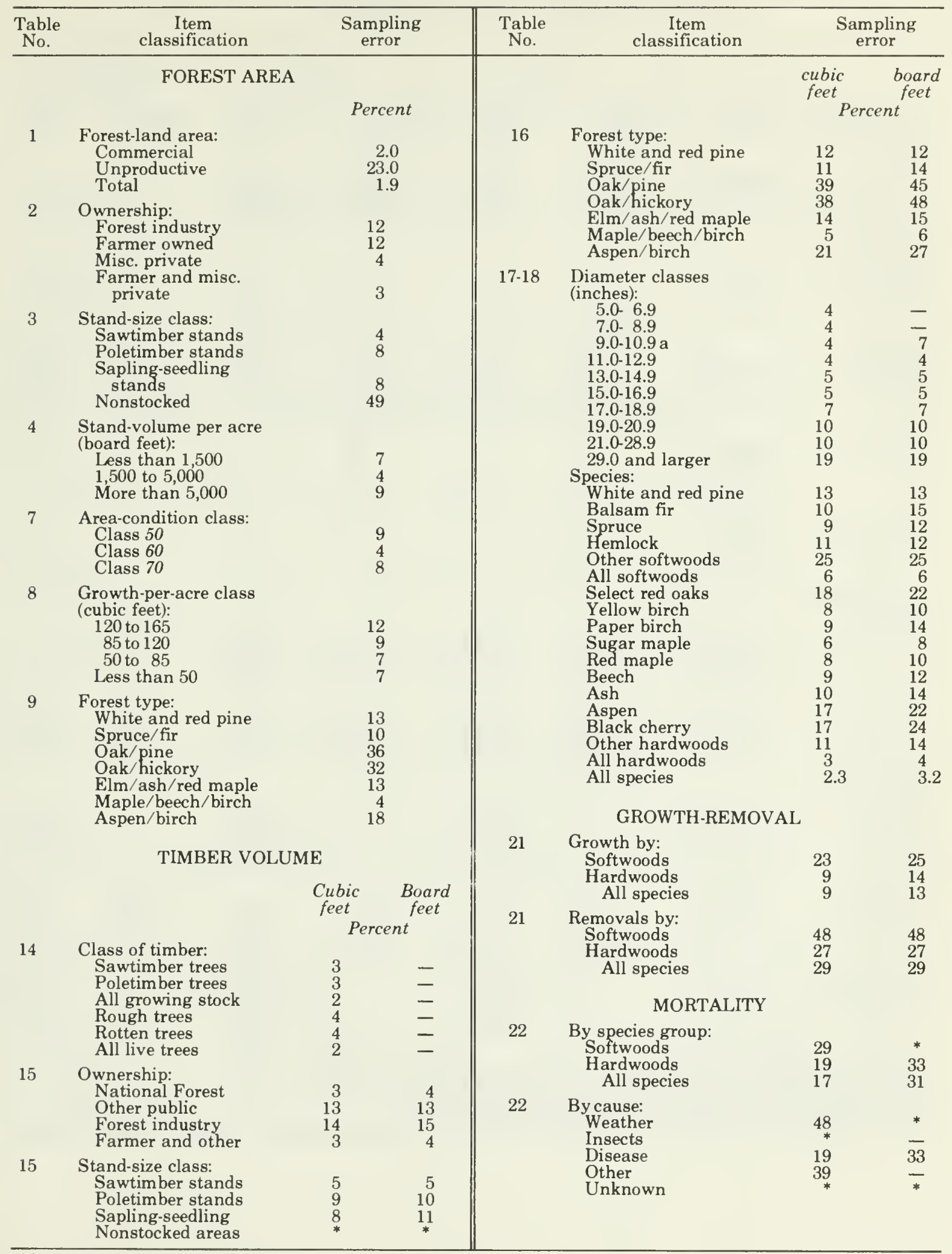

"Sampling errors of 50 to 99 percent.

a Board-foot sampling error for this class is for softwoods only. 
Table 25.-Output of timber products, by source of material, softwoods and hardwoods, Vermont, 1972

\begin{tabular}{|c|c|c|c|c|c|c|c|}
\hline \multirow[b]{2}{*}{$\begin{array}{l}\text { Product and } \\
\text { species group }\end{array}$} & \multirow[b]{2}{*}{$\begin{array}{l}\text { Standard } \\
\text { units }\end{array}$} & \multicolumn{2}{|c|}{ Total output } & \multicolumn{2}{|c|}{$\begin{array}{l}\text { Output from } \\
\text { roundwood }\end{array}$} & \multicolumn{2}{|c|}{$\begin{array}{l}\text { Output from } \\
\text { plant byproducts }\end{array}$} \\
\hline & & $\begin{array}{l}\text { Number } \\
\text { of units }\end{array}$ & $\begin{array}{l}\text { Thousand } \\
\text { cubic } \\
\text { feet }\end{array}$ & $\begin{array}{l}\text { Number } \\
\text { of units }\end{array}$ & $\begin{array}{l}\text { Thousand } \\
\text { cubic } \\
\text { feet }\end{array}$ & $\begin{array}{l}\text { Number } \\
\text { of units }\end{array}$ & $\begin{array}{l}\text { Thousand } \\
\text { cubic } \\
\text { feet }\end{array}$ \\
\hline $\begin{array}{l}\text { Sawlogs: } \\
\text { Softwood } \\
\text { Hardwood }\end{array}$ & $\begin{array}{l}\text { M bd. ft. a } \\
\text { M bd. ft. a }\end{array}$ & $\begin{array}{l}55,224 \\
69,949\end{array}$ & $\begin{array}{r}8,460 \\
11,269\end{array}$ & $\begin{array}{l}55,224 \\
69,949\end{array}$ & $\begin{array}{r}8,460 \\
11,269\end{array}$ & $\underline{-}$ & $\overline{-}$ \\
\hline Total & M bd. ft. a & 125,173 & 19,729 & 125,173 & 19,729 & - & - \\
\hline $\begin{array}{l}\text { Veneer logs } \\
\text { and bolts: } \\
\text { Softwood } \\
\text { Hardwood }\end{array}$ & $\begin{array}{l}\text { M bd. ft. a } \\
\text { M bd. ft. a }\end{array}$ & $6,9 \overline{77}$ & $1,1 \overline{24}$ & $6,9 \overline{7}$ & $1, \overline{124}$ & - & - \\
\hline Total & $\mathrm{M}$ bd. ft. a & 6,977 & 1,124 & 6,977 & 1,124 & - & - \\
\hline $\begin{array}{l}\text { Pulpwood: } \\
\text { Softwood } \\
\text { Hardwood }\end{array}$ & $\begin{array}{l}\text { Std. cords b } \\
\text { Std. cords b }\end{array}$ & $\begin{array}{r}62,656 \\
103,948\end{array}$ & $\begin{array}{l}5,325 \\
8,836\end{array}$ & $\begin{array}{l}56,900 \\
78,619\end{array}$ & $\begin{array}{l}4,836 \\
6,683\end{array}$ & $\begin{array}{r}5,756 \\
25,329\end{array}$ & $\begin{array}{r}489 \\
2,153\end{array}$ \\
\hline Total & Std. cords b & 166,604 & 14,161 & 135,519 & 11,519 & 31,085 & $2,642^{\mathrm{c}}$ \\
\hline $\begin{array}{l}\text { Piling: } \\
\text { Softwood } \\
\text { Hardwood }\end{array}$ & $\begin{array}{l}\text { M linear ft. } \\
\mathrm{M} \text { linear } \mathrm{ft} .\end{array}$ & $\begin{array}{l}88 \\
13\end{array}$ & $\begin{array}{r}54 \\
7\end{array}$ & $\begin{array}{l}88 \\
13\end{array}$ & $\begin{array}{r}54 \\
7\end{array}$ & 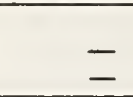 & - \\
\hline Total & M linear $\mathrm{ft}$. & 101 & 61 & 101 & 61 & - & - \\
\hline $\begin{array}{l}\text { Poles: } \\
\text { Softwood } \\
\text { Hardwood }\end{array}$ & $\begin{array}{l}\text { M pieces } \\
\text { M pieces }\end{array}$ & 2 & $\frac{6}{-}$ & $\underline{2}$ & $\frac{6}{-}$ & - & - \\
\hline Total & $\mathrm{M}$ pieces & 2 & 6 & 2 & 6 & - & - \\
\hline $\begin{array}{l}\text { Post (round } \\
\text { and split): } \\
\text { Softwood } \\
\text { Hardwood }\end{array}$ & $\begin{array}{l}\text { M pieces } \\
\text { M pieces }\end{array}$ & $\begin{array}{l}388 \\
115\end{array}$ & $\begin{array}{r}343 \\
86\end{array}$ & $\begin{array}{l}388 \\
115\end{array}$ & $\begin{array}{r}343 \\
86\end{array}$ & - & - \\
\hline Total & M pieces & 503 & 429 & 503 & 429 & - & - \\
\hline $\begin{array}{l}\text { Other:d } \\
\text { Softwood } \\
\text { Hardwood }\end{array}$ & $\begin{array}{l}\text { M cu. ft. } \\
\text { M cu. ft. }\end{array}$ & $\begin{array}{r}797 \\
2,679 \\
\end{array}$ & $\begin{array}{r}797 \\
2,679\end{array}$ & $\begin{array}{r}747 \\
2,456 \\
\end{array}$ & $\begin{array}{r}747 \\
2,456 \\
\end{array}$ & $\begin{array}{r}50 \\
223 \\
\end{array}$ & $\begin{array}{r}50 \\
223 \\
\end{array}$ \\
\hline Total & M cu. ft. & 3,476 & 3,476 & 3,203 & 3,203 & 273 & 273 \\
\hline $\begin{array}{l}\text { Total industrial } \\
\text { products: } \\
\text { Softwood } \\
\text { Hardwood }\end{array}$ & $\begin{array}{l}\text { M cu. ft. } \\
\text { M cu. ft. }\end{array}$ & $=$ & $\begin{array}{l}14,985 \\
24,001\end{array}$ & $=$ & $\begin{array}{l}14,446 \\
21,625\end{array}$ & $=$ & $\begin{array}{r}539 \\
2,376\end{array}$ \\
\hline Total & $\mathrm{M}$ cu. ft. & - & 38,986 & - & 36,071 & - & 2,915 \\
\hline $\begin{array}{l}\text { Fuelwood: } \\
\text { Softwood } \\
\text { Hardwood }\end{array}$ & $\begin{array}{l}\text { Std. cords } \\
\text { Std. cords }\end{array}$ & $\begin{array}{r}4,762 \\
49,425\end{array}$ & $\begin{array}{r}381 \\
3,954\end{array}$ & $36,0 \overline{70}$ & $2,8 \overline{86}$ & $\begin{array}{r}4,762 \\
13,350\end{array}$ & $\begin{array}{r}381 \\
1,068\end{array}$ \\
\hline Total & Std. cords & 54,187 & 4,335 & 36,070 & 2,886 & 18,112 & 1,449 \\
\hline $\begin{array}{l}\text { All products: e } \\
\text { Softwood } \\
\text { Hardwood }\end{array}$ & $\begin{array}{l}\text { M cu. ft. } \\
\text { M cu. ft. }\end{array}$ & - & $\begin{array}{l}15,366 \\
27,955\end{array}$ & $=$ & $\begin{array}{l}14,446 \\
24,511\end{array}$ & - & $\begin{array}{r}920 \\
3,444 \\
\end{array}$ \\
\hline Total & M cu. ft. & - & 43,321 & - & 38,957 & - & 4,364 \\
\hline
\end{tabular}

a International $1 / 4$-inch rule.

bRough wood basis, includes chips converted to equivalent standard cords.

cPulpwood from plant residues does not agree with table 6 in Resource Bulletin NE-35, Primary Wood.Products Industries of New Hampshire and Vermont, 1972, because of different data sources.

d Includes dimension, excelsior, and turnery bolts; and novelty fencing.

eDoes not include $1,102,884$ cubic feet of softwood and 1,969,216 cubic feet of hardwood residues used for agricultural bedding. 
Table 27. - Timber removals from growing stock and sawtimber on commercial forest land, by items, softwoods and hardwoods, Vermont, 1972

\begin{tabular}{|c|c|c|c|c|c|c|}
\hline \multirow{2}{*}{ Item } & \multicolumn{3}{|c|}{ Growing stock } & \multicolumn{3}{|c|}{ Sawtimber } \\
\hline & $\begin{array}{c}\text { All } \\
\text { species }\end{array}$ & $\begin{array}{l}\text { Soft- } \\
\text { woods }\end{array}$ & $\begin{array}{l}\text { Hard- } \\
\text { woods }\end{array}$ & $\begin{array}{l}\text { All } \\
\text { species }\end{array}$ & $\begin{array}{l}\text { Soft- } \\
\text { woods }\end{array}$ & $\begin{array}{l}\text { Hard- } \\
\text { woods }\end{array}$ \\
\hline Roundwood & \multicolumn{3}{|c|}{ - - Thousand cubic feet -} & \multicolumn{3}{|c|}{-- Thousand board feet ${ }^{a}--$} \\
\hline $\begin{array}{l}\text { products: } \\
\text { Sawlogs } \\
\text { Veneer logs }\end{array}$ & 17,811 & 7,425 & 10,386 & 87,882 & 35,689 & 52,193 \\
\hline $\begin{array}{l}\text { and bolts } \\
\text { Pulpwood }\end{array}$ & $\begin{array}{l}1,055 \\
9,604\end{array}$ & $4, \overline{35}$ & $\begin{array}{l}1,055 \\
5,069\end{array}$ & $\begin{array}{r}4,711 \\
34,372\end{array}$ & $15,3 \overline{74}$ & $\begin{array}{r}4,711 \\
18,998\end{array}$ \\
\hline Piling & 54 & 48 & 6 & 265 & 234 & 31 \\
\hline $\begin{array}{l}\text { Poles } \\
\text { Posts }\end{array}$ & $\begin{array}{r}5 \\
382\end{array}$ & 316 & $\overline{66}$ & 1,023 & $\begin{array}{r}12 \\
858\end{array}$ & $1 \overline{65}$ \\
\hline Other & 2,575 & 689 & 1,886 & 6,538 & 1,869 & 4,669 \\
\hline Fuelwood & 1,388 & - & 1,388 & 1,243 & - & 1,243 \\
\hline All products & 32,874 & 13,018 & 19,856 & 136,046 & 54,036 & 82,010 \\
\hline $\begin{array}{l}\text { Logging residues } \\
\text { Other removals }\end{array}$ & $\begin{array}{l}8,189 \\
6,895\end{array}$ & $\begin{array}{l}2,689 \\
2,943\end{array}$ & $\begin{array}{l}5,500 \\
3,952\end{array}$ & $\begin{array}{l}15,608 \\
13,142\end{array}$ & $\begin{array}{l}4,498 \\
4,866\end{array}$ & $\begin{array}{r}11,110 \\
8,276\end{array}$ \\
\hline Total removals & 47,958 & 18,650 & 29,308 & 164,796 & 63,400 & 101,396 \\
\hline
\end{tabular}

anternational $1 / 4$-inch rule.

Table 28. - Volume of unused residues at primary manufacturing plants, by industry and type of residues, and softwoods and hardwoods, Vermont, 1972

[In thousands of cubic feet]

\begin{tabular}{|c|c|c|c|c|}
\hline $\begin{array}{l}\text { Species groups and } \\
\text { type of residues }\end{array}$ & $\begin{array}{c}\text { All } \\
\text { industries }\end{array}$ & Lumber & $\begin{array}{c}\text { Veneer and } \\
\text { plywood }\end{array}$ & Other \\
\hline $\begin{array}{l}\text { Softwoods: } \\
\text { Coarse }^{\mathrm{a}} \\
\text { Fine }^{\mathrm{b}}\end{array}$ & $\begin{array}{r}323 \\
83\end{array}$ & $\begin{array}{r}323 \\
83\end{array}$ & - & $\overline{-}$ \\
\hline Total & 406 & 406 & - & - \\
\hline $\begin{array}{l}\text { Hardwoods: } \\
\text { Coarse } \mathrm{a}^{\mathrm{a}} \\
\text { Fine }^{\mathrm{b}}\end{array}$ & $\begin{array}{l}221 \\
144\end{array}$ & $\begin{array}{l}217 \\
142\end{array}$ & - & $\begin{array}{l}4 \\
2\end{array}$ \\
\hline Total & 365 & 359 & - & 6 \\
\hline $\begin{array}{c}\text { All species: } \\
\text { Coarse }^{\mathrm{a}} \\
\text { Fine }^{\mathrm{b}}\end{array}$ & $\begin{array}{l}544 \\
227\end{array}$ & $\begin{array}{l}540 \\
225\end{array}$ & - & $\begin{array}{l}4 \\
2 \\
\end{array}$ \\
\hline Total & 771 & 765 & - & 6 \\
\hline
\end{tabular}

a Material such as slabs, edgings, and veneer cores.

b Material such as sawdust and shavings. 
Table 29.-Projections of net annual growth, timber removals, and inventory of growing stock and sawtimber on commercial forest land in Vermont, 1973-2003

\begin{tabular}{|c|c|c|c|c|}
\hline $\begin{array}{l}\text { Species } \\
\text { group }\end{array}$ & $\begin{array}{c}1973 \\
\text { (inventory } \\
\text { year) }\end{array}$ & 1983 & 1993 & 2003 \\
\hline & \multicolumn{2}{|c|}{$\begin{array}{l}\text { GROWING STOCK } \\
\text { Million cubic feet }\end{array}$} & & \\
\hline $\begin{array}{l}\text { Softwoods: } \\
\text { Removals } \\
\text { Growth } \\
\text { Inventory }\end{array}$ & $\begin{array}{r}19.4 \\
46.5 \\
1,718.0\end{array}$ & $\begin{array}{r}25 \\
47 \\
2,081\end{array}$ & $\begin{array}{r}34 \\
52 \\
2,371\end{array}$ & $\begin{array}{r}44 \\
56 \\
2,613\end{array}$ \\
\hline $\begin{array}{l}\text { Hardwoods: } \\
\text { Removals } \\
\text { Growth } \\
\text { Inventory }\end{array}$ & $\begin{array}{r}28.4 \\
60.1 \\
3,012.2\end{array}$ & $\begin{array}{r}43 \\
75 \\
3,108\end{array}$ & $\begin{array}{r}63 \\
87 \\
3,302\end{array}$ & $\begin{array}{r}83 \\
98 \\
3,407\end{array}$ \\
\hline $\begin{array}{l}\text { Total: } \\
\text { Removals } \\
\text { Growth } \\
\text { Inventory }\end{array}$ & $\begin{array}{r}47.8 \\
106.6 \\
4,730.2\end{array}$ & $\begin{array}{r}68 \\
122 \\
5,189\end{array}$ & $\begin{array}{r}97 \\
139 \\
5,673\end{array}$ & $\begin{array}{r}127 \\
154 \\
6,020 \\
\end{array}$ \\
\hline \multicolumn{5}{|c|}{$\begin{array}{c}\text { SAWTIMBER } \\
\text { Million board feet }\end{array}$} \\
\hline $\begin{array}{l}\text { Softwoods: } \\
\text { Removals } \\
\text { Growth } \\
\text { Inventory }\end{array}$ & $\begin{array}{r}52.0 \\
129.0 \\
3,875.5\end{array}$ & $\begin{array}{r}68 \\
134 \\
4,627\end{array}$ & $\begin{array}{r}93 \\
150 \\
5,249\end{array}$ & $\begin{array}{r}121 \\
162 \\
5,758\end{array}$ \\
\hline $\begin{array}{c}\text { Hardwoods: } \\
\text { Removals } \\
\text { Growth } \\
\text { Inventory }\end{array}$ & $\begin{array}{r}66.0 \\
133.0 \\
5,845.2\end{array}$ & $\begin{array}{r}100 \\
166 \\
6,032\end{array}$ & $\begin{array}{r}146 \\
192 \\
6,409\end{array}$ & $\begin{array}{r}193 \\
217 \\
6,613\end{array}$ \\
\hline $\begin{array}{l}\text { Total: } \\
\text { Removals } \\
\text { Growth } \\
\text { Inventory }\end{array}$ & $\begin{array}{r}118.0 \\
262.0 \\
9,720.7\end{array}$ & $\begin{array}{r}168 \\
300 \\
10,659\end{array}$ & $\begin{array}{r}239 \\
342 \\
11,658\end{array}$ & $\begin{array}{r}314 \\
379 \\
12,371\end{array}$ \\
\hline
\end{tabular}

aBased upon the following assumptions: the area of commercial forest land will begin a slow decrease after 1980; net annual growth as a percent of inventory is expected to increase from 2.3 to 2.6 percent; timber removals will reflect expected timber-product demands and land-use changes. 
Table 30.-Area by land classes, geographic units, and counties, Vermont, 1973

\begin{tabular}{|c|c|c|c|c|c|c|}
\hline \multirow{2}{*}{$\begin{array}{l}\text { Unit and } \\
\text { county }\end{array}$} & \multirow{2}{*}{$\begin{array}{c}\text { Total } \\
\text { land area }\end{array}$} & \multirow{2}{*}{$\begin{array}{l}\text { Nonforest } \\
\text { land area }\end{array}$} & \multicolumn{4}{|c|}{ Forest-land area } \\
\hline & & & $\begin{array}{l}\text { Non- } \\
\text { commercial b }\end{array}$ & Commercial & & ing \\
\hline & ----- & - - - Thou & nd acres - - & ----- & & \\
\hline $\begin{array}{l}\text { Caledonia } \\
\text { Essex } \\
\text { Franklin } \\
\text { Grand Isle } \\
\text { Lamoille } \\
\text { Orange } \\
\text { Orleans } \\
\text { Washington }\end{array}$ & $\begin{array}{r}391.9 \\
424.5 \\
422.7 \\
53.3 \\
303.6 \\
441.7 \\
457.4 \\
452.8 \\
\end{array}$ & $\begin{array}{r}96.3 \\
27.2 \\
184.6 \\
53.3 \\
49.2 \\
105.3 \\
118.3 \\
86.8 \\
\end{array}$ & $\begin{array}{r}4.3 \\
1.2 \\
1.2 \\
-\overline{3.2} \\
.5 \\
.1 \\
4.7\end{array}$ & $\begin{array}{r}291.3 \\
396.1 \\
236.9 \\
-\overline{-} \\
251.2 \\
335.9 \\
339.0 \\
361.3\end{array}$ & $\begin{array}{l}74 \\
93 \\
56 \\
83 \\
76 \\
74 \\
80\end{array}$ & $\begin{array}{r}8 \\
2 \\
15 \\
5 \\
7 \\
8 \\
6\end{array}$ \\
\hline Northern Unit & $2,947.9$ & 721.0 & 15.2 & $2,211.7$ & 75 & 3 \\
\hline $\begin{array}{l}\text { Addison } \\
\text { Bennington } \\
\text { Chittenden } \\
\text { Rutland } \\
\text { Windham } \\
\text { Windsor }\end{array}$ & $\begin{array}{l}501.5 \\
430.2 \\
341.1 \\
593.3 \\
503.6 \\
617.8 \\
\end{array}$ & $\begin{array}{r}209.2 \\
54.1 \\
127.9 \\
139.3 \\
72.1 \\
118.1 \\
\end{array}$ & $\begin{array}{r}6.5 \\
5.4 \\
17.5 \\
9.1 \\
3.0 \\
7.1 \\
\end{array}$ & $\begin{array}{l}285.8 \\
370.7 \\
195.7 \\
444.9 \\
428.5 \\
492.6 \\
\end{array}$ & $\begin{array}{l}57 \\
86 \\
57 \\
75 \\
85 \\
80 \\
\end{array}$ & $\begin{array}{r}16 \\
3 \\
14 \\
7 \\
4 \\
6\end{array}$ \\
\hline Southern Unit & $2,987.5$ & 720.7 & 48.6 & $2,218.2$ & 74 & 3 \\
\hline Total & $5,935.4$ & $1,441.7$ & 63.8 & $4,429.9$ & 75 & 2 \\
\hline
\end{tabular}

a Source: Areas of Vermont: 1960 (January 1967), Bureau of the Census.

b Includes nonproductive and productive-reserved forest land.

c In percent for commercial forest land at the 68-percent probability level.

Table 31.-Area of commercial forest land, by ownership classes, geographic units, and counties, Vermont, 1973

[In thousands of acres]

\begin{tabular}{|c|c|c|c|c|c|c|}
\hline \multirow{2}{*}{$\begin{array}{l}\text { Unit and } \\
\text { County }\end{array}$} & \multicolumn{3}{|c|}{ Public-owned ${ }^{\text {a }}$} & \multicolumn{2}{|c|}{ Private-owned } & \multirow[b]{2}{*}{ Total } \\
\hline & $\begin{array}{l}\text { National } \\
\text { Forestb }\end{array}$ & State & $\begin{array}{l}\text { County and } \\
\text { municipal }\end{array}$ & $\begin{array}{l}\text { Farmer- } \\
\text { owned }\end{array}$ & $\begin{array}{l}\text { Other } \\
\text { private }\end{array}$ & \\
\hline $\begin{array}{l}\text { Caledonia } \\
\text { Essex } \\
\text { Franklin } \\
\text { Lamoille } \\
\text { Orange } \\
\text { Orleans } \\
\text { Washington }\end{array}$ & $\begin{array}{l}\bar{z} \\
\bar{z} \\
0.9 \\
\overline{3.3}\end{array}$ & $\begin{array}{r}29.4 \\
15.2 \\
1.3 \\
7.8 \\
4.8 \\
8.9 \\
29.0\end{array}$ & $\begin{array}{r}2.4 \\
.9 \\
.5 \\
6.0 \\
2.7 \\
1.4 \\
5.0\end{array}$ & $\begin{array}{l}59.3 \\
18.6 \\
66.2 \\
25.2 \\
59.2 \\
77.2 \\
42.0\end{array}$ & $\begin{array}{l}200.2 \\
361.4 \\
168.9 \\
212.2 \\
268.3 \\
251.5 \\
282.0\end{array}$ & $\begin{array}{l}291.3 \\
396.1 \\
236.9 \\
251.2 \\
335.9 \\
339.0 \\
361.3 \\
\end{array}$ \\
\hline Northern Unit & 4.2 & 96.4 & 18.9 & 347.7 & $1,744.5$ & $2,211.7$ \\
\hline $\begin{array}{l}\text { Addison } \\
\text { Bennington } \\
\text { Chittenden } \\
\text { Rutland } \\
\text { Windham } \\
\text { Windsor }\end{array}$ & $\begin{array}{l}78.1 \\
64.3 \\
48.9 \\
15.8 \\
21.1\end{array}$ & $\begin{array}{r}6.1 \\
7.5 \\
8.6 \\
17.5 \\
3.7 \\
28.4\end{array}$ & $\begin{array}{r}2.6 \\
2.2 \\
2.0 \\
10.2 \\
2.1 \\
3.0\end{array}$ & $\begin{array}{l}43.2 \\
20.7 \\
35.6 \\
69.9 \\
35.1 \\
56.2\end{array}$ & $\begin{array}{l}155.8 \\
276.0 \\
149.5 \\
298.4 \\
371.8 \\
383.9\end{array}$ & $\begin{array}{l}285.8 \\
370.7 \\
195.7 \\
444.9 \\
428.5 \\
492.6 \\
\end{array}$ \\
\hline Southern Unit & 228.2 & 71.8 & 22.1 & 260.7 & $1,635.4$ & $2,218.2$ \\
\hline Total & 232.4 & 168.2 & 41.0 & 608.4 & $3,379.9$ & $\overline{4,429.9}$ \\
\hline
\end{tabular}

a From ownership records.

bIncludes 3,800 acres of other federal ownerships. 
Tale 32.-Area of commercial forest land, by stand-size classes, geographic units, and counties, Vermont, 1973

[In thousands of acres]

\begin{tabular}{lrrrrr}
\hline \multicolumn{1}{c}{$\begin{array}{c}\text { Unit and } \\
\text { county }\end{array}$} & $\begin{array}{c}\text { Sawtimber } \\
\text { stands }\end{array}$ & $\begin{array}{c}\text { Poletimber } \\
\text { stands }\end{array}$ & $\begin{array}{c}\text { Sapling- } \\
\text { seedling } \\
\text { stands }\end{array}$ & $\begin{array}{c}\text { Nonstocked } \\
\text { areas }\end{array}$ & Total \\
\hline Caledonia & 113.0 & 53.5 & 123.5 & 1.3 & 291.3 \\
Essex & 199.5 & 82.8 & 112.9 & .9 & 396.1 \\
Franklin & 62.9 & 35.5 & 136.8 & 1.7 & 236.9 \\
Lamoille & 120.9 & 51.4 & 78.0 & .9 & 251.2 \\
Orange & 138.9 & 60.7 & 134.9 & 1.4 & 335.9 \\
Orleans & 145.2 & 62.4 & 129.8 & 1.6 & 339.0 \\
Washington & 169.3 & 71.0 & 119.6 & 1.4 & 361.3 \\
$\quad$ Northern Unit & 949.7 & 417.3 & 835.5 & 9.2 & $2,211.7$ \\
Addison & 137.6 & 67.9 & 77.1 & 3.2 & 285.8 \\
Bennington & 194.2 & 97.2 & 75.3 & 4.0 & 370.7 \\
Chittenden & 84.1 & 41.5 & 66.4 & 3.7 & 195.7 \\
Rutland & 220.7 & 106.3 & 111.3 & 6.6 & 444.9 \\
Windham & 219.6 & 108.4 & 95.3 & 5.2 & 428.5 \\
Windsor & 255.2 & 115.9 & 115.6 & 5.9 & 492.6 \\
$\quad$ Southern Unit & $1,111.4$ & 537.2 & 541.0 & 28.6 & $2,218.2$ \\
Total & $2,061.1$ & 954.5 & $1,376.5$ & 37.8 & $4,429.9$ \\
\hline
\end{tabular}

Table 33.-Area of commercial forest land, by stand-volume classes and geographic units, Vermont, 1973

\begin{tabular}{lccccrr}
\hline $\begin{array}{l}\text { Stand-volume } \\
\text { per acre } \\
\text { (board feet) }\end{array}$ & \multicolumn{2}{c}{ Northern Unit } & \multicolumn{2}{c}{ Southern Unit } & \multicolumn{2}{c}{ State total } \\
\cline { 2 - 7 } & $\begin{array}{c}\text { Thousand } \\
\text { acres }\end{array}$ & Percent & $\begin{array}{c}\text { Thousand } \\
\text { acres }\end{array}$ & Percent & $\begin{array}{c}\text { Thousand } \\
\text { acres }\end{array}$ & Percent \\
\hline Less than 1,500 & 784.4 & 36 & 767.9 & 35 & $1,552.3$ & 35 \\
1,500 to 5,000 & $1,000.6$ & 45 & $1,094.2$ & 49 & $2,094.8$ & 772.8 \\
More than 5,000 & 426.7 & 19 & 356.1 & 16 & 18 \\
All classes & $2,211.7$ & 100 & $2,218.2$ & 100 & $4,429.9$ & 100 \\
\hline
\end{tabular}

\footnotetext{
a International $1 / 4$-inch rule.
}

Table 34.-Area of commercial forest land, by potential site productivity and geographic units, Vermont, 1973

[In thousands of acres]

\begin{tabular}{cccr}
\hline $\begin{array}{c}\text { Growth-per- } \\
\text { acre class } \\
\text { (cubic feet) }\end{array}$ & $\begin{array}{c}\text { Northern } \\
\text { Unit }\end{array}$ & $\begin{array}{c}\text { Southern } \\
\text { Unit }\end{array}$ & Total \\
\hline 120 to 165 & 370.1 & 104.4 & 474.5 \\
85 to 120 & 509.4 & 352.8 & 862.2 \\
50 to 85 & 689.2 & 914.1 & $1,603.3$ \\
Less than 50 & 643.0 & 846.9 & $1,489.9$ \\
All classes & $2,211.7$ & $2,218.2$ & $4,429.9$ \\
\hline
\end{tabular}


Table 35.-Area of commercial forest land, by forest types, geographic units, and counties, Vermont, 1973

[In thousands of acres]

\begin{tabular}{|c|c|c|c|c|c|c|c|c|}
\hline \multirow[b]{2}{*}{$\begin{array}{l}\text { Unit and } \\
\text { county }\end{array}$} & \multicolumn{6}{|c|}{ Forest type } & \multirow[b]{2}{*}{$\begin{array}{c}\text { Aspen/ } \\
\text { birch }\end{array}$} & \multirow[b]{2}{*}{ Total } \\
\hline & $\begin{array}{l}\text { White and } \\
\text { red pine }\end{array}$ & $\underset{\text { fir }}{\text { Spruce/ }}$ & $\begin{array}{c}\text { Oak/ } \\
\text { pine }\end{array}$ & $\begin{array}{c}\text { Oak/ } \\
\text { hickory }\end{array}$ & $\begin{array}{l}\text { Elm/ash/ } \\
\text { red maple }\end{array}$ & $\begin{array}{c}\text { Maple/ } \\
\text { beech/ } \\
\text { birch }\end{array}$ & & \\
\hline $\begin{array}{l}\text { Caledonia } \\
\text { Essex } \\
\text { Franklin } \\
\text { Lamoille } \\
\text { Orange } \\
\text { Orleans } \\
\text { Washington }\end{array}$ & $\begin{array}{l}36.9 \\
46.5 \\
33.2 \\
29.3 \\
43.1 \\
42.3 \\
41.0\end{array}$ & $\begin{array}{r}87.6 \\
100.8 \\
79.5 \\
66.2 \\
97.1 \\
99.7 \\
96.1\end{array}$ & $\begin{array}{l}1.0 \\
2.1 \\
.5 \\
1.3 \\
1.5 \\
1.5 \\
2.1\end{array}$ & $\begin{array}{l}= \\
= \\
= \\
=\end{array}$ & $\begin{array}{l}30.3 \\
28.7 \\
37.9 \\
21.1 \\
34.3 \\
32.7 \\
30.1\end{array}$ & $\begin{array}{r}120.8 \\
198.7 \\
75.8 \\
121.4 \\
145.4 \\
147.5 \\
175.7\end{array}$ & $\begin{array}{l}14.7 \\
19.3 \\
10.0 \\
11.9 \\
14.5 \\
15.3 \\
16.3\end{array}$ & $\begin{array}{l}291.3 \\
396.1 \\
236.9 \\
251.2 \\
335.9 \\
339.0 \\
361.3\end{array}$ \\
\hline Northern Unit & 272.3 & 627.0 & 10.0 & - & 215.1 & 985.3 & 102.0 & $2,211.7$ \\
\hline $\begin{array}{l}\text { Addison } \\
\text { Bennington } \\
\text { Chittenden } \\
\text { Rutland } \\
\text { Windham } \\
\text { Windsor }\end{array}$ & $\begin{array}{l}49.9 \\
52.2 \\
42.6 \\
73.6 \\
73.0 \\
86.5 \\
\end{array}$ & $\begin{array}{l}19.6 \\
25.9 \\
13.8 \\
30.9 \\
30.1 \\
37.1 \\
\end{array}$ & $\begin{array}{r}7.7 \\
9.1 \\
9.8 \\
16.1 \\
14.3 \\
18.3 \\
\end{array}$ & $\begin{array}{r}\overline{7.1} \\
3.6 \\
35.4 \\
24.8\end{array}$ & $\begin{array}{l}30.5 \\
46.5 \\
27.5 \\
57.7 \\
60.1 \\
67.5\end{array}$ & $\begin{array}{r}100.5 \\
206.5 \\
85.7 \\
231.8 \\
186.7 \\
225.9\end{array}$ & $\begin{array}{l}17.6 \\
23.4 \\
16.3 \\
31.2 \\
28.9 \\
32.5 \\
\end{array}$ & $\begin{array}{l}285.8 \\
370.7 \\
195.7 \\
444.9 \\
4285 \\
492.6 \\
\end{array}$ \\
\hline Southern Unit & 377.8 & 157.4 & 75.3 & 70.9 & 289.8 & $1,097.1$ & 149.9 & $2,218.2$ \\
\hline Total & 650.1 & 784.4 & 85.3 & 70.9 & 504.9 & $2,082.4$ & 251.9 & $4,429.9$ \\
\hline
\end{tabular}

Table 36. - Net volume of timber on commercial forest land, by class of timber and geographic units, Vermont, 1973

[In millions of cubic feet]

\begin{tabular}{lrrr}
\hline Class of timber & $\begin{array}{c}\text { Northern } \\
\text { Unit }\end{array}$ & \multicolumn{1}{c}{$\begin{array}{c}\text { Southern } \\
\text { Unit }\end{array}$} & Total \\
\hline Sawtimber trees: & & & \\
Sawlog portion & 987.9 & 993.8 & $1,981.7$ \\
Upper-stem portion & 195.3 & 209.0 & 404.3 \\
\cline { 2 - 4 } All sawtimber trees & $1,183.2$ & $1,202.8$ & $2,386.0$ \\
Poletimber trees & $1,204.8$ & $1,139.4$ & $2,344.2$ \\
\cline { 2 - 4 } All growing-stock trees & $2,388.0$ & $2,342.2$ & $4,730.2$ \\
\cline { 2 - 4 } Rough trees & 330.2 & 504.5 & 834.7 \\
Rotten trees & 164.2 & 175.8 & 340.0 \\
Total, all timber & $2,882.4$ & $3,022.5$ & $5,904.9$ \\
\hline
\end{tabular}


Table 37.-Net volume of growing stock on commercial forest land, by tree classes, geographic units, and counties, Vermont, 1973

[In millions of cubic feet]

\begin{tabular}{lrcr}
\hline $\begin{array}{c}\text { Unit and } \\
\text { county }\end{array}$ & $\begin{array}{c}\text { Sawtimber } \\
\text { trees }\end{array}$ & $\begin{array}{c}\text { Poletimber } \\
\text { trees }\end{array}$ & $\begin{array}{c}\text { Total } \\
\text { growing } \\
\text { stock }\end{array}$ \\
\hline Caledonia & 150.6 & 151.7 & 302.3 \\
Essex & 241.1 & 238.9 & 480.0 \\
Franklin & 89.0 & 101.8 & 190.8 \\
Lamoille & 146.1 & 146.5 & 292.6 \\
Orange & 172.8 & 179.6 & 352.4 \\
Orleans & 181.6 & 183.5 & 365.1 \\
Washington & 202.0 & 202.8 & 404.8 \\
\hline Northern Unit & $1,183.2$ & $1,204.8$ & $2,388.0$ \\
Addison & 143.6 & 132.9 & 276.5 \\
Bennington & 206.3 & 193.6 & 399.9 \\
Chittenden & 94.5 & 94.5 & 189.0 \\
Rutland & 237.1 & 225.7 & 462.8 \\
Windham & 242.2 & 231.1 & 473.3 \\
Windsor & 279.1 & 261.6 & 540.7 \\
$\quad$ Southern Unit & $1,202.8$ & $1,139.4$ & $2,342.2$ \\
\hline Total & $2,386.0$ & $2,344.2$ & $4,730.2$ \\
\hline
\end{tabular}

Table 38. - Net volume of growing stock and sawtimber on commercial forest land, by ownership classes, softwoods and hardwoods, and geographic units, Vermont, 1973

\begin{tabular}{|c|c|c|c|c|c|c|}
\hline \multirow{2}{*}{$\begin{array}{l}\text { Ownership } \\
\text { class }\end{array}$} & \multicolumn{3}{|c|}{$\begin{array}{c}\text { Growing stock } \\
\text { (million cubic feet) }\end{array}$} & \multicolumn{3}{|c|}{$\begin{array}{c}\text { Sawtimber } \\
\text { (million board feet)a }\end{array}$} \\
\hline & All species & Softwoods & Hardwoods & All species & Softwoods & Hardwoods \\
\hline & \multicolumn{6}{|c|}{ NORTHERN UNIT } \\
\hline $\begin{array}{l}\text { National Forest } \\
\text { Other public } \\
\text { Forest industry } \\
\text { Farmer and other }\end{array}$ & $\begin{array}{r}2.8 \\
132.8 \\
547.4 \\
1,705.0 \\
\end{array}$ & $\begin{array}{r}0.4 \\
55.4 \\
158.1 \\
884.9 \\
\end{array}$ & $\begin{array}{r}2.4 \\
77.4 \\
389.3 \\
820.1 \\
\end{array}$ & $\begin{array}{r}6.5 \\
299.6 \\
1,211.5 \\
3,374.8 \\
\end{array}$ & $\begin{array}{r}0.8 \\
132.9 \\
350.2 \\
1,811.8 \\
\end{array}$ & $\begin{array}{r}5.7 \\
166.7 \\
861.3 \\
1,563.0 \\
\end{array}$ \\
\hline \multirow[t]{2}{*}{ All ownerships } & $2,388.0$ & $1,098.8$ & $1,289.2$ & $4,892.4$ & $2,295.7$ & $2,596.7$ \\
\hline & \multicolumn{6}{|c|}{ SOUTHERN UNIT } \\
\hline $\begin{array}{l}\text { National Forest } \\
\text { Other public } \\
\text { Forest industry } \\
\text { Farmer and other }\end{array}$ & $\begin{array}{r}199.1 \\
103.1 \\
159.7 \\
1,880.3\end{array}$ & $\begin{array}{r}39.7 \\
30.8 \\
41.5 \\
507.2\end{array}$ & $\begin{array}{r}159.4 \\
72.3 \\
118.2 \\
1,373.1\end{array}$ & $\begin{array}{r}425.1 \\
224.5 \\
342.8 \\
3,835.9\end{array}$ & $\begin{array}{r}64.4 \\
74.8 \\
100.0 \\
1,340.6\end{array}$ & $\begin{array}{r}360.7 \\
149.7 \\
242.8 \\
2,495.3\end{array}$ \\
\hline All ownerships & $2,342.2$ & 619.2 & $1,723.0$ & $4,828.3$ & $1,579.8$ & $3,248.5$ \\
\hline
\end{tabular}

a International $1 / 4$-inch rule. 
Table 39. - Net volume of growing stock and sawtimber on commercial forest land, by stand-size classes, softwoods and hardwoods, and geographic units, Vermont, 1973

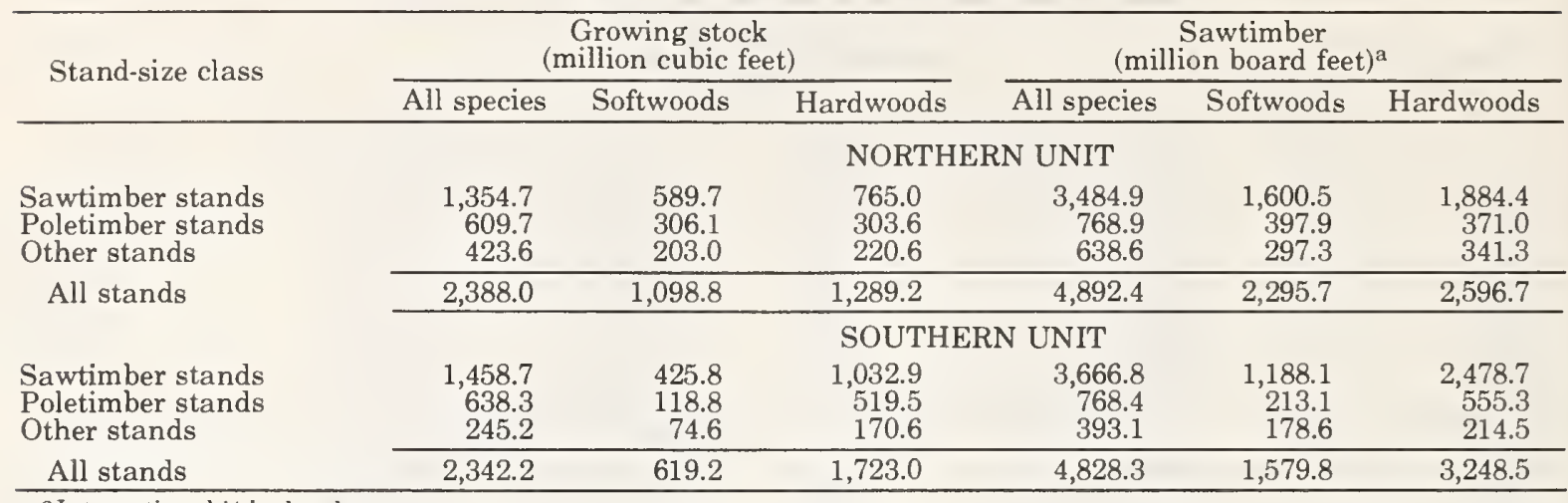

Table 40.-Net volume of growing stock on commercial forest land, by stand-size classes, geographic units, and counties, Vermont, 1973

\begin{tabular}{|c|c|c|c|c|c|}
\hline $\begin{array}{l}\text { Unit and } \\
\text { county }\end{array}$ & $\begin{array}{l}\text { Sawtimber } \\
\text { stands }\end{array}$ & $\begin{array}{l}\text { Poletimber } \\
\text { stands }\end{array}$ & $\begin{array}{l}\text { Other } \\
\text { stands }\end{array}$ & Total & $\begin{array}{c}\text { Sampling } \\
\text { error } \\
\text { of total }\end{array}$ \\
\hline & \multicolumn{4}{|c|}{----- Million cubic feet -----} & Percent \\
\hline Caledonia & 164.6 & 76.2 & 61.5 & 302.3 & 9 \\
\hline Essex & 285.8 & 125.7 & 68.5 & 480.0 & 7 \\
\hline Franklin & 87.8 & 47.7 & 55.3 & 190.8 & 13 \\
\hline Lamoille & 172.6 & 78.0 & 42.0 & 292.6 & 10 \\
\hline Orange & 197.2 & 86.8 & 68.4 & 352.4 & 9 \\
\hline Orleans & 208.8 & 90.8 & 65.5 & 365.1 & 9 \\
\hline Washington & 237.9 & 104.5 & 62.4 & 404.8 & 8 \\
\hline Northern Unit & $1,354.7$ & 609.7 & 423.6 & $2,388.0$ & 3 \\
\hline Addison & 170.5 & 77.1 & 28.9 & 276.5 & 9 \\
\hline Bennington & 249.2 & 114.0 & 36.7 & 399.9 & 7 \\
\hline Chittenden & 109.9 & 50.8 & 28.3 & 189.0 & 13 \\
\hline Rutland & 287.0 & 126.1 & 49.7 & 462.8 & 7 \\
\hline Windham & 295.6 & 130.3 & 47.4 & 473.3 & 7 \\
\hline Windsor & 346.5 & 140.0 & 54.2 & 540.7 & 7 \\
\hline \multirow{2}{*}{$\begin{array}{l}\text { Southern Unit } \\
\text { Total }\end{array}$} & $1,458.7$ & 638.3 & 245.2 & $2,342.2$ & 3 \\
\hline & $2,813.4$ & $1,248.0$ & 668.8 & $4,730.2$ & 2 \\
\hline
\end{tabular}


Table 41.- Net volume of sawtimber on commercial forest land,

by stand-size classes, geographic units, and counties,

Vermont, 1973

\begin{tabular}{|c|c|c|c|c|c|}
\hline $\begin{array}{l}\text { Unit and } \\
\text { county }\end{array}$ & $\begin{array}{l}\text { Sawtimber } \\
\text { stands }\end{array}$ & $\begin{array}{c}\text { Poletimber } \\
\text { stands }\end{array}$ & $\begin{array}{l}\text { Other } \\
\text { stands }\end{array}$ & Total & $\begin{array}{c}\text { Sampling } \\
\text { error } \\
\text { of total }\end{array}$ \\
\hline & \multicolumn{4}{|c|}{------ Million board feet ${ }^{\mathrm{a}}----$} & Percent \\
\hline Caledonia & 431.3 & 94.3 & 97.0 & 622.6 & 13 \\
\hline Essex & 732.9 & 163.2 & 101.6 & 997.7 & 10 \\
\hline Franklin & 225.5 & 54.1 & .6 .9 & 366.5 & 17 \\
\hline Lamoille & 441.9 & 101.3 & 61.5 & 604.7 & 14 \\
\hline Orange & 504.3 & 107.4 & 102.2 & 713.9 & 13 \\
\hline Orleans & 539.1 & 114.5 & 97.3 & 750.9 & 13 \\
\hline Washington & 609.9 & 134.1 & 92.1 & 836.1 & 11 \\
\hline Northern Unit & $3,484.9$ & 768.9 & 638.6 & $4,892.4$ & 5 \\
\hline Addison & 433.5 & 90.9 & 47.6 & 572.0 & 12 \\
\hline Bennington & 629.5 & 136.6 & 59.9 & 826.0 & 9 \\
\hline Chittenden & 274.1 & 62.1 & 45.1 & 381.3 & 18 \\
\hline Rutland & 718.7 & 152.6 & 79.9 & 951.2 & 10 \\
\hline Windham & 741.0 & 158.1 & 75.9 & 975.0 & 10 \\
\hline Windsor & 870.0 & 168.1 & 84.7 & $1,122.8$ & 10 \\
\hline Southern Unit & $3,666.8$ & 768.4 & 393.1 & $4,828.3$ & 5 \\
\hline Total & $7,151.7$ & $1,537.3$ & $1,031.7$ & $9,720.7$ & 3 \\
\hline
\end{tabular}

a International $1 / 4$-inch rule.

Table 42. - Net volume of growing stock on commercial forest land, by forest types, geographic units, and counties, Vermont, 1973

[In millions of cubic feet]

\begin{tabular}{|c|c|c|c|c|c|c|c|c|}
\hline \multirow[b]{2}{*}{$\begin{array}{l}\text { Unit and } \\
\text { county }\end{array}$} & \multicolumn{6}{|c|}{ Forest type } & \multirow[b]{2}{*}{$\begin{array}{c}\text { Aspen/ } \\
\text { birch }\end{array}$} & \multirow[b]{2}{*}{ Total } \\
\hline & $\begin{array}{l}\text { White and } \\
\text { red pine }\end{array}$ & $\begin{array}{l}\text { Spruce/ } \\
\text { fir }\end{array}$ & $\begin{array}{c}\text { Oak/ } \\
\text { pine }\end{array}$ & $\begin{array}{l}\text { Oak/ } \\
\text { hickory }\end{array}$ & $\begin{array}{l}\mathrm{Elm} / \mathrm{ash} / \\
\text { red maple }\end{array}$ & $\begin{array}{c}\text { Maple/ } \\
\text { beech } \\
\text { birch }\end{array}$ & & \\
\hline $\begin{array}{l}\text { Caledonia } \\
\text { Sssex } \\
\text { ranklin } \\
\text { amoille } \\
\text { Prange } \\
\text { Prleans } \\
\text { Nashington }\end{array}$ & $\begin{array}{l}49.7 \\
67.7 \\
35.3 \\
41.0 \\
54.6 \\
56.0 \\
56.7\end{array}$ & $\begin{array}{r}93.4 \\
132.4 \\
60.3 \\
80.2 \\
101.1 \\
106.9 \\
108.8\end{array}$ & $\begin{array}{l}2.2 \\
4.5 \\
1.0 \\
2.7 \\
3.2 \\
3.3 \\
4.4\end{array}$ & $\begin{array}{l}- \\
- \\
- \\
-\end{array}$ & $\begin{array}{l}23.9 \\
34.4 \\
19.7 \\
21.9 \\
27.8 \\
28.1 \\
29.5\end{array}$ & $\begin{array}{r}118.3 \\
219.3 \\
65.3 \\
133.1 \\
151.8 \\
155.2 \\
188.2\end{array}$ & $\begin{array}{r}14.8 \\
21.7 \\
9.2 \\
13.7 \\
13.9 \\
15.6 \\
17.2\end{array}$ & $\begin{array}{l}302.3 \\
480.0 \\
190.8 \\
292.6 \\
352.4 \\
365.1 \\
404.8\end{array}$ \\
\hline Northern Unit & 361.0 & 683.1 & 21.3 & - & 185.3 & $1,031.2$ & 106.1 & $2,388.0$ \\
\hline $\begin{array}{l}\text { Addison } \\
\text { Bennington } \\
\text { Chittenden } \\
\text { Rutland } \\
\text { Nindham } \\
\text { Nindsor }\end{array}$ & $\begin{array}{r}40.7 \\
61.1 \\
39.0 \\
78.1 \\
88.8 \\
104.4 \\
\end{array}$ & $\begin{array}{l}19.2 \\
25.8 \\
11.5 \\
29.7 \\
27.6 \\
35.5 \\
\end{array}$ & $\begin{array}{r}6.0 \\
8.7 \\
6.5 \\
12.0 \\
12.3 \\
14.4 \\
\end{array}$ & $\begin{array}{r}\overline{8.0} \\
\overline{4} \\
39.1 \\
28.0\end{array}$ & $\begin{array}{l}32.5 \\
52.8 \\
26.5 \\
62.3 \\
67.9 \\
76.5\end{array}$ & $\begin{array}{r}162.3 \\
220.1 \\
91.5 \\
248.6 \\
208.0 \\
251.8 \\
\end{array}$ & $\begin{array}{l}15.8 \\
23.4 \\
14.0 \\
28.0 \\
28.8 \\
30.1 \\
\end{array}$ & $\begin{array}{l}276.5 \\
399.9 \\
189.0 \\
462.8 \\
473.3 \\
540.7 \\
\end{array}$ \\
\hline Jouthern Unit & 412.1 & 149.3 & 59.9 & 80.0 & 318.5 & $1,182.3$ & 140.1 & $2,342.2$ \\
\hline Total & 773.1 & 832.4 & 81.2 & 80.0 & 503.8 & $2,213.5$ & 246.2 & $4,730.2$ \\
\hline
\end{tabular}




\section{Table 43. - Net volume of sawtimber on commercial forest land, by forest types, geographic units, and counties, Vermont, 1973}

[In millions of board feet] ${ }^{\mathrm{a}}$

\begin{tabular}{|c|c|c|c|c|c|c|c|c|}
\hline \multirow{2}{*}{$\begin{array}{l}\text { Unit and } \\
\text { county }\end{array}$} & \multicolumn{7}{|c|}{ Forest type } & \multirow[b]{2}{*}{ Total } \\
\hline & $\begin{array}{l}\text { White and } \\
\text { red pine }\end{array}$ & $\begin{array}{l}\text { Spruce/ } \\
\text { fir }\end{array}$ & $\begin{array}{l}\text { Oak/ } \\
\text { pine }\end{array}$ & $\begin{array}{c}\text { Oak/ } \\
\text { hickory }\end{array}$ & $\begin{array}{l}\text { Elm/ash/ } \\
\text { red maple }\end{array}$ & $\begin{array}{c}\text { Maple/ } \\
\text { beech/ } \\
\text { birch }\end{array}$ & $\begin{array}{c}\text { Aspen/ } \\
\text { birch }\end{array}$ & \\
\hline $\begin{array}{l}\text { Caldeonia } \\
\text { Essex } \\
\text { Franklin } \\
\text { Lamoille } \\
\text { Orange } \\
\text { Orleans } \\
\text { Washington }\end{array}$ & $\begin{array}{r}117.7 \\
169.3 \\
73.4 \\
101.7 \\
126.8 \\
134.8 \\
135.8 \\
\end{array}$ & $\begin{array}{r}170.3 \\
231.9 \\
95.8 \\
139.1 \\
169.3 \\
187.5 \\
186.9 \\
\end{array}$ & $\begin{array}{r}4.5 \\
10.9 \\
2.5 \\
6.5 \\
8.0 \\
7.8 \\
9.6 \\
\end{array}$ & $\begin{array}{l}= \\
= \\
= \\
=\end{array}$ & $\begin{array}{l}37.0 \\
50.7 \\
28.6 \\
31.7 \\
41.1 \\
41.5 \\
43.8 \\
\end{array}$ & $\begin{array}{l}276.7 \\
507.3 \\
157.1 \\
308.5 \\
352.6 \\
360.8 \\
438.2 \\
\end{array}$ & $\begin{array}{r}16.4 \\
27.6 \\
9.1 \\
17.2 \\
16.1 \\
18.5 \\
21.8 \\
\end{array}$ & $\begin{array}{l}622.6 \\
997.7 \\
366.5 \\
604.7 \\
713.9 \\
750.9 \\
836.1 \\
\end{array}$ \\
\hline Northern Unit & 859.5 & $1,180.8$ & 49.8 & - & 274.4 & $2,401.2$ & 126.7 & $4,892.4$ \\
\hline $\begin{array}{l}\text { Addison } \\
\text { Bennington } \\
\text { Chittenden } \\
\text { Rutland } \\
\text { Windham } \\
\text { Windsor }\end{array}$ & $\begin{array}{r}100.6 \\
148.2 \\
95.5 \\
188.4 \\
216.0 \\
255.0 \\
\end{array}$ & $\begin{array}{l}27.9 \\
41.5 \\
21.7 \\
48.8 \\
51.6 \\
64.5 \\
\end{array}$ & $\begin{array}{r}10.5 \\
17.4 \\
9.7 \\
20.7 \\
23.4 \\
25.2 \\
\end{array}$ & $\begin{array}{r}17.5 \\
\overline{8.8} \\
87.0 \\
60.9 \\
\end{array}$ & $\begin{array}{r}68.4 \\
113.4 \\
57.0 \\
132.7 \\
145.1 \\
161.7 \\
\end{array}$ & $\begin{array}{l}347.8 \\
461.2 \\
184.4 \\
521.2 \\
419.2 \\
521.5 \\
\end{array}$ & $\begin{array}{l}16.8 \\
26.8 \\
13.0 \\
30.6 \\
32.7 \\
34.0 \\
\end{array}$ & $\begin{array}{r}572.0 \\
826.0 \\
381.3 \\
951.2 \\
975.0 \\
1,122.8 \\
\end{array}$ \\
\hline Southern Unit & $1,003.7$ & 256.0 & 106.9 & 174.2 & 678.3 & $2,455.3$ & 153.9 & $4,828.3$ \\
\hline Total & $1,863.2$ & $1,436.8$ & 156.7 & 174.2 & 952.7 & $4,856.5$ & 280.6 & $9,720.7$ \\
\hline
\end{tabular}

${ }^{a}$ International 1/4-inch rule.

Table 44.-Net volume of growing stock on commercial forest land in Northern geographic unit, by species and counties, Vermont, 1973

[In millions of cubic feet]

\begin{tabular}{|c|c|c|c|c|c|c|c|c|}
\hline \multirow{2}{*}{ Species } & \multicolumn{7}{|c|}{ Counties } & \multirow{2}{*}{$\begin{array}{l}\text { Norther } \\
\text { Unit }\end{array}$} \\
\hline & Caledonia & Essex & Franklin & Lamoille & Orange & Orelans & Washington & \\
\hline $\begin{array}{l}\text { White and red pine } \\
\text { Balsam fir } \\
\text { Spruce } \\
\text { Hemlock } \\
\text { Other softwoods }\end{array}$ & $\begin{array}{l}22.5 \\
40.6 \\
51.8 \\
22.7 \\
11.1 \\
\end{array}$ & $\begin{array}{l}25.5 \\
60.1 \\
76.1 \\
36.3 \\
14.7 \\
\end{array}$ & $\begin{array}{r}20.4 \\
26.4 \\
32.0 \\
12.9 \\
6.8 \\
\end{array}$ & $\begin{array}{r}16.1 \\
35.8 \\
46.6 \\
21.8 \\
8.9 \\
\end{array}$ & $\begin{array}{l}23.4 \\
47.4 \\
55.2 \\
26.0 \\
10.9 \\
\end{array}$ & $\begin{array}{l}23.1 \\
47.9 \\
59.8 \\
27.8 \\
11.7 \\
\end{array}$ & $\begin{array}{l}23.5 \\
50.3 \\
61.9 \\
29.0 \\
11.8 \\
\end{array}$ & $\begin{array}{r}154.5 \\
308.5 \\
383.4 \\
176.5 \\
75.9 \\
\end{array}$ \\
\hline Total softwoods & 148.7 & 212.7 & 98.5 & 129.2 & 162.9 & 170.3 & 176.5 & $1,098.8$ \\
\hline $\begin{array}{l}\text { Select red oaks } \\
\text { Yellow birch } \\
\text { Paper birch } \\
\text { Sugar maple } \\
\text { Red maple } \\
\text { Beech } \\
\text { Ash } \\
\text { Aspen } \\
\text { Black cherry } \\
\text { Other hardwoods }\end{array}$ & $\begin{array}{r}.5 \\
19.9 \\
14.6 \\
61.1 \\
24.5 \\
11.6 \\
6.8 \\
7.4 \\
1.5 \\
5.7 \\
\end{array}$ & $\begin{array}{r}.5 \\
35.1 \\
23.1 \\
109.3 \\
39.0 \\
24.3 \\
13.5 \\
11.2 \\
3.1 \\
8.2 \\
\end{array}$ & $\begin{array}{r}.4 \\
10.0 \\
9.6 \\
35.0 \\
16.9 \\
6.2 \\
4.0 \\
5.4 \\
.8 \\
4.0 \\
\end{array}$ & $\begin{array}{r}.3 \\
21.6 \\
14.5 \\
66.6 \\
24.1 \\
14.7 \\
8.2 \\
6.6 \\
1.9 \\
4.9 \\
\end{array}$ & $\begin{array}{r}.5 \\
23.1 \\
16.3 \\
76.3 \\
29.0 \\
17.0 \\
9.5 \\
9.2 \\
1.9 \\
6.7 \\
\end{array}$ & $\begin{array}{r}.4 \\
24.5 \\
17.3 \\
78.5 \\
29.7 \\
17.1 \\
9.6 \\
8.9 \\
2.1 \\
6.7 \\
\end{array}$ & $\begin{array}{r}.5 \\
30.1 \\
19.7 \\
93.7 \\
33.0 \\
21.1 \\
11.6 \\
9.3 \\
2.5 \\
6.8 \\
\end{array}$ & $\begin{array}{r}3.1 \\
164.3 \\
115.1 \\
520.5 \\
196.2 \\
112.0 \\
63.2 \\
58.0 \\
13.8 \\
43.0 \\
\end{array}$ \\
\hline Total hardwoods & 153.6 & 267.3 & 92.3 & 163.4 & 189.5 & 194.8 & 228.3 & $1,289.2$ \\
\hline All species & 302.3 & 480.0 & 190.8 & 292.6 & 352.4 & 365.1 & 404.8 & $2,388.0$ \\
\hline
\end{tabular}


Table 45. - Net volume of growing stock on commercial forest land in Southern geographic unit, by species and counties, Vermont, 1973

[In millions of cubic feet]

\section{Species}

White and red pine
Balsam fir
Spruce
Hemlock
Other softwoods
Total softwoods
Select red oaks
Yellow birch
Paper birch
Sugar maple
Red maple
Beech
Ash
Aspen
Black cherry
Other hardwoods
Total hardwoods
All species

$$
\text { Counties }
$$

\begin{tabular}{|c|c|c|c|c|c|c|}
\hline \multicolumn{6}{|c|}{ Councies } & \multirow{2}{*}{$\begin{array}{l}\text { Southerr } \\
\text { Unit }\end{array}$} \\
\hline Addison & Bennington & Chittenden & Rutland & Windham & Windsor & \\
\hline 22.0 & 33.4 & 23.9 & 43.4 & 50.3 & 59.6 & 232.6 \\
\hline 5.8 & 5.9 & 1.8 & 6.3 & 3.8 & 5.6 & 29.2 \\
\hline $\begin{array}{r}19.4 \\
19.4\end{array}$ & 26.0 & 11.1 & 29.7 & 28.0 & 34.7 & 148.9 \\
\hline 20.9 & 32.9 & 16.0 & 38.7 & 43.6 & 50.0 & 202.1 \\
\hline .6 & 1.0 & 1.0 & 1.2 & 1.3 & 1.3 & 6.4 \\
\hline 68.7 & 99.2 & 53.8 & 119.3 & 127.0 & 151.2 & 619.2 \\
\hline 11.6 & 18.1 & 9.2 & 22.1 & 23.3 & 25.7 & 110.0 \\
\hline 23.9 & 31.0 & 10.4 & 34.2 & 30.4 & 37.5 & 167.4 \\
\hline 19.5 & 28.3 & 14.3 & 33.7 & 33.6 & 37.6 & 167.0 \\
\hline 70.8 & 100.8 & 42.5 & 113.0 & 110.7 & 124.9 & 562.7 \\
\hline 27.8 & 43.7 & 19.9 & 50.0 & 53.5 & 59.2 & 254.1 \\
\hline 16.6 & 22.6 & 9.0 & 24.4 & 24.2 & 27.5 & 124.3 \\
\hline 13.8 & 20.2 & 10.0 & 23.6 & 23.9 & 26.6 & 118.1 \\
\hline 8.3 & 12.3 & 8.0 & 15.3 & 16.2 & 17.1 & 77.2 \\
\hline 4.2 & 5.9 & 2.8 & 6.3 & 6.7 & 6.8 & 32.7 \\
\hline 11.3 & 17.8 & 9.1 & 20.9 & 23.8 & 26.6 & 109.5 \\
\hline 207.8 & 300.7 & 135.2 & 343.5 & 346.3 & 389.5 & $1,723.0$ \\
\hline 276.5 & 399.9 & 189.0 & 462.8 & 473.3 & 540.7 & $2,342.2$ \\
\hline
\end{tabular}

\section{Table 46. - Net volume of sawtimber on commercial forest land in Northern geographic unit, by species and counties, Vermont, 1973}

[In millions of board feet] $^{a}$

\begin{tabular}{|c|c|c|c|c|c|c|c|c|}
\hline \multirow{2}{*}{ Species } & \multicolumn{7}{|c|}{ coumles } & \multirow{2}{*}{$\begin{array}{c}\text { Northern } \\
\text { Unit }\end{array}$} \\
\hline & Caledonia & Essex & Franklin & Lamoille & Orange & Orelans & Washington & \\
\hline $\begin{array}{l}\text { White and red pine } \\
\text { Balsam fir } \\
\text { Spruce } \\
\text { Hemlock } \\
\text { Other softwoods }\end{array}$ & $\begin{array}{r}55.8 \\
59.0 \\
117.8 \\
65.7 \\
16.5 \\
\end{array}$ & $\begin{array}{r}75.1 \\
93.9 \\
161.8 \\
104.1 \\
21.5 \\
\end{array}$ & $\begin{array}{r}41.8 \\
36.5 \\
65.9 \\
34.7 \\
8.3 \\
\end{array}$ & $\begin{array}{l}45.9 \\
55.5 \\
97.7 \\
62.3 \\
13.0 \\
\end{array}$ & $\begin{array}{r}60.5 \\
71.2 \\
114.3 \\
73.0 \\
15.1 \\
\end{array}$ & $\begin{array}{r}61.0 \\
71.9 \\
128.4 \\
79.7 \\
17.4 \\
\end{array}$ & $\begin{array}{r}64.1 \\
77.4 \\
129.0 \\
82.1 \\
17.8 \\
\end{array}$ & $\begin{array}{l}404.2 \\
465.4 \\
814.9 \\
501.6 \\
109.6 \\
\end{array}$ \\
\hline Total softwoods & 314.8 & 456.4 & 187.2 & 274.4 & 334.1 & 358.4 & 370.4 & $2,295.7$ \\
\hline $\begin{array}{l}\text { Select red oaks } \\
\text { Yellow birch } \\
\text { Paper birch } \\
\text { Sugar maple } \\
\text { Red maple } \\
\text { Beech } \\
\text { Ash } \\
\text { Aspen } \\
\text { Black cherry } \\
\text { Other hardwoods }\end{array}$ & $\begin{array}{r}1.8 \\
47.3 \\
13.6 \\
138.5 \\
38.1 \\
30.2 \\
12.9 \\
7.6 \\
3.0 \\
14.8 \\
\end{array}$ & $\begin{array}{r}1.9 \\
84.7 \\
22.8 \\
242.6 \\
61.3 \\
62.8 \\
24.9 \\
12.4 \\
6.4 \\
21.5 \\
\end{array}$ & $\begin{array}{r}1.3 \\
23.9 \\
7.0 \\
82.6 \\
23.9 \\
16.7 \\
7.3 \\
4.7 \\
1.6 \\
10.3\end{array}$ & $\begin{array}{r}1.0 \\
51.8 \\
13.9 \\
147.9 \\
38.6 \\
37.9 \\
15.1 \\
7.3 \\
4.0 \\
12.8 \\
\end{array}$ & $\begin{array}{r}1.8 \\
56.5 \\
15.5 \\
171.7 \\
42.2 \\
44.7 \\
17.1 \\
9.7 \\
3.6 \\
17.0 \\
\end{array}$ & $\begin{array}{r}1.7 \\
59.5 \\
16.7 \\
176.8 \\
45.2 \\
44.5 \\
17.5 \\
9.5 \\
4.0 \\
17.1 \\
\end{array}$ & $\begin{array}{r}1.8 \\
73.8 \\
19.2 \\
208.8 \\
53.0 \\
54.4 \\
21.3 \\
11.0 \\
5.0 \\
17.4 \\
\end{array}$ & $\begin{array}{r}11.3 \\
397.5 \\
108.7 \\
1,168.9 \\
302.3 \\
291.2 \\
116.1 \\
62.2 \\
27.6 \\
110.9\end{array}$ \\
\hline Total hardwoods & 307.8 & 541.3 & 179.3 & 330.3 & 379.8 & 392.5 & 465.7 & $2,596.7$ \\
\hline All species & 622.6 & 997.7 & 366.5 & 604.7 & 713.9 & 750.9 & 836.1 & $4,892.4$ \\
\hline
\end{tabular}

\section{Counties}


Table 47.-Net volume of sawtimber on commercial forest land in Southern geographic unit, by species and counties, Vermont, 1973

[In millions of board feet] ${ }^{\mathrm{a}}$

\begin{tabular}{|c|c|c|c|c|c|c|c|}
\hline \multirow{2}{*}{ Species } & \multicolumn{6}{|c|}{ Counties } & \multirow{2}{*}{$\begin{array}{c}\text { Souther } \\
\text { Unit }\end{array}$} \\
\hline & Addison & Bennington & Chittenden & Rutland & Windham & Windsor & \\
\hline $\begin{array}{l}\text { White and red pine } \\
\text { Balsam fir } \\
\text { Spruce } \\
\text { Hemlock } \\
\text { Other softwoods }\end{array}$ & $\begin{array}{r}62.9 \\
2.6 \\
41.5 \\
57.9 \\
1.8 \\
\end{array}$ & $\begin{array}{r}98.1 \\
3.4 \\
57.1 \\
89.8 \\
2.8 \\
\end{array}$ & $\begin{array}{r}65.9 \\
2.0 \\
23.9 \\
43.0 \\
2.8 \\
\end{array}$ & $\begin{array}{r}123.8 \\
4.0 \\
64.7 \\
105.9 \\
3.1 \\
\end{array}$ & $\begin{array}{r}145.5 \\
3.3 \\
62.5 \\
116.9 \\
3.7 \\
\end{array}$ & $\begin{array}{r}170.0 \\
4.6 \\
77.4 \\
135.5 \\
3.4 \\
\end{array}$ & $\begin{array}{r}666.2 \\
19.9 \\
327.1 \\
549.0 \\
17.6 \\
\end{array}$ \\
\hline Total softwoods & 166.7 & 251.2 & 137.6 & 301.5 & 331.9 & 390.9 & $1,579.8$ \\
\hline $\begin{array}{l}\text { Select red oaks } \\
\text { Yellow birch } \\
\text { Paper birch } \\
\text { Sugar maple } \\
\text { Red maple } \\
\text { Beech } \\
\text { Ash } \\
\text { Aspen } \\
\text { Black cherry } \\
\text { Other hardwoods }\end{array}$ & $\begin{array}{r}31.2 \\
49.3 \\
26.1 \\
150.7 \\
49.0 \\
37.0 \\
25.4 \\
10.4 \\
5.5 \\
20.7 \\
\end{array}$ & $\begin{array}{r}51.5 \\
63.1 \\
38.4 \\
208.6 \\
76.6 \\
49.5 \\
34.5 \\
15.5 \\
8.0 \\
29.1 \\
\end{array}$ & $\begin{array}{r}22.4 \\
20.9 \\
18.2 \\
84.3 \\
35.7 \\
19.3 \\
13.4 \\
8.8 \\
4.2 \\
16.5 \\
\end{array}$ & $\begin{array}{r}60.3 \\
70.9 \\
44.7 \\
23.1 \\
86.7 \\
52.6 \\
38.7 \\
18.5 \\
95.2 \\
35.0 \\
\end{array}$ & $\begin{array}{r}66.2 \\
59.6 \\
46.0 \\
22.9 \\
93.3 \\
51.8 \\
36.0 \\
19.0 \\
9.3 \\
39.0 \\
\end{array}$ & $\begin{array}{r}72.1 \\
75.2 \\
51.1 \\
256.9 \\
100.9 \\
60.0 \\
41.5 \\
19.3 \\
10.4 \\
44.5 \\
\end{array}$ & $\begin{array}{r}303.7 \\
339.0 \\
224.5 \\
1,156.5 \\
442.2 \\
270.2 \\
189.5 \\
91.5 \\
46.6 \\
184.8 \\
\end{array}$ \\
\hline Total hardwoods & 405.3 & 574.8 & 243.7 & 649.7 & 643.1 & 731.9 & $3,248.5$ \\
\hline All species & 572.0 & 826.0 & 381.3 & 951.2 & 975.0 & $1,122.8$ & $4,828.3$ \\
\hline
\end{tabular}

anternational 1/4-inch rule.

Table 48. - Net volume of growing stock on commercial forest land in Northern geographic unit, by species and diameter classes, Vermont, 1973

[In millions of cubic feet]

\begin{tabular}{|c|c|c|c|c|c|c|c|c|c|c|c|}
\hline \multirow{2}{*}{ Species } & \multirow{2}{*}{$\begin{array}{c}\text { All } \\
\text { classes }\end{array}$} & \multicolumn{10}{|c|}{ (Diameter class (inches at breast height) } \\
\hline & & $\begin{array}{l}5.0- \\
6.9\end{array}$ & $\begin{array}{l}7.0- \\
8.9\end{array}$ & $\begin{array}{r}9.0- \\
10.9\end{array}$ & $\begin{array}{l}11.0- \\
12.9\end{array}$ & $\begin{array}{l}13.0- \\
14.9\end{array}$ & $\begin{array}{l}15.0- \\
16.9\end{array}$ & $\begin{array}{l}17.0- \\
18.9\end{array}$ & $\begin{array}{l}19.0- \\
20.9\end{array}$ & $\begin{array}{l}21.0- \\
28.9\end{array}$ & $29.0^{+}$ \\
\hline White and red pine & 154.5 & 27.3 & 31.5 & 17.1 & 16.7 & 15.9 & 10.6 & 11.2 & 6.1 & 16.1 & 2.0 \\
\hline Balsam fir & 308. & 96.2 & 91.4 & 66.6 & & & 5.8 & 1.7 & $\overline{1}$ & $\overline{31}$ & - \\
\hline $\begin{array}{l}\text { Spruce } \\
\text { Hemlock }\end{array}$ & $\begin{array}{l}383.4 \\
1765\end{array}$ & 83 & 96.0 & $\begin{array}{l}84.0 \\
37.9\end{array}$ & $\begin{array}{r}54.0 \\
31.4\end{array}$ & 31.8 & 19.7 & 6.6 & 4.1 & 3.4 & - \\
\hline Other softwoods & 75.9 & 28.0 & 18.9 & 14.9 & $\begin{array}{r}0.4 \\
8.7\end{array}$ & 2.6 & 1.5 & 1.3 & - & - & 二 \\
\hline Total softwoods & $1,098.8$ & 258.9 & 265.1 & 220.5 & 142.7 & 92.4 & 48.2 & 28.5 & 18.1 & 22.4 & 2.0 \\
\hline Select red oaks & 3.1 & .1 & - & .6 & .1 & .7 & - & - & - & 1.6 & \\
\hline Yellow b & 164.3 & 20.7 & 23.1 & 28.9 & 20.6 & 24.5 & 18.8 & 11.2 & 7.1 & 6.9 & 2.5 \\
\hline Pape & 115.1 & 26.3 & 36.7 & 25.9 & 12.8 & 7.5 & 4.3 & 1.6 & - & - & - \\
\hline & 520. & 64.6 & 92.6 & 93.0 & 86.1 & 60.3 & 35.1 & 34.4 & 14.2 & 34.2 & 6.0 \\
\hline Red 1 & 196.2 & 32.3 & 41.9 & 48.0 & 34.4 & 18.4 & 10.7 & 5.4 & 3.3 & 1.4 & .4 \\
\hline & 112.0 & 6.7 & 20.2 & 16.7 & 16. & 22.5 & 10.8 & 11.2 & 4.5 & 3.1 & - \\
\hline & 63.2 & 9.4 & 12.4 & 13.7 & 13. & 7.4 & 2. & 2.2 & .7 & 1.3 & .5 \\
\hline Aspe & 58.0 & 14.6 & 17.0 & 11.4 & 4. & 6.9 & 2. & .6 & - & - & - \\
\hline Blacl & 13.8 & 1.6 & 1.9 & 3.7 & $2 .($ & 1.9 & 2.2 & .4 & .1 & - & - \\
\hline Other hardwoods & 43.0 & 4.5 & 6.2 & 6.1 & 10.2 & 5.1 & 2.6 & 3.6 & 1.6 & 2.1 & 1.0 \\
\hline Total hardwoods & $1,289.2$ & 180.8 & 252.0 & 248.0 & 200.4 & 155.2 & 89.7 & 70.6 & 31.5 & 50.6 & 10.4 \\
\hline All species & $2,388.0$ & 439.7 & 517.1 & 468.5 & 343.1 & 247.6 & 137.9 & 99.1 & 49.6 & 73.0 & $\overline{12.4}$ \\
\hline
\end{tabular}


Table 49. - Net volume of growing stock on commercial forest land in Southern geographic unit, by species and diameter classes, Vermont, 1973

[In millions of cubic feet]

\begin{tabular}{|c|c|c|c|c|c|c|c|c|c|c|c|}
\hline \multirow{2}{*}{ Species } & \multirow{2}{*}{$\begin{array}{c}\text { All } \\
\text { classes }\end{array}$} & \multicolumn{10}{|c|}{ Diameter class (inches at breast height) } \\
\hline & & $\begin{array}{l}5.0- \\
6.9\end{array}$ & $\begin{array}{l}7.0- \\
8.9\end{array}$ & $\begin{array}{r}9.0- \\
10.9\end{array}$ & $\begin{array}{l}11.0- \\
12.9\end{array}$ & $\begin{array}{l}13.0- \\
14.9\end{array}$ & $\begin{array}{l}15.0- \\
16.9\end{array}$ & $\begin{array}{l}17.0- \\
18.9\end{array}$ & $\begin{array}{l}19.0 \\
20.9\end{array}$ & $\begin{array}{l}21.0- \\
28.9\end{array}$ & $29.0^{+}$ \\
\hline $\begin{array}{l}\text { White and red pine } \\
\text { Balsam fir } \\
\text { Spruce } \\
\text { Hemlock } \\
\text { Other softwoods }\end{array}$ & $\begin{array}{r}232.6 \\
29.2 \\
148.9 \\
202.1 \\
6.4 \\
\end{array}$ & $\begin{array}{r}31.1 \\
12.2 \\
33.9 \\
26.2 \\
1.2 \\
\end{array}$ & $\begin{array}{r}35.7 \\
10.9 \\
31.4 \\
37.5 \\
.6 \\
\end{array}$ & $\begin{array}{r}42.7 \\
4.7 \\
27.1 \\
34.4 \\
1.8 \\
\end{array}$ & $\begin{array}{r}30.4 \\
1.3 \\
24.8 \\
40.4 \\
2.1 \\
\end{array}$ & $\begin{array}{r}29.9 \\
.1 \\
20.3 \\
26.8 \\
.7\end{array}$ & $\begin{array}{r}27.2 \\
7.6 \\
16.0 \\
- \\
\end{array}$ & $\begin{array}{r}17.5 \\
1.0 \\
8.7 \\
-\end{array}$ & $\begin{array}{l}5.6 \\
1.6 \\
7.2 \\
- \\
\end{array}$ & $\begin{array}{r}11.0 \\
1.2 \\
4.9 \\
- \\
\end{array}$ & $\begin{array}{l}1.5 \\
- \\
-\end{array}$ \\
\hline Total softwoods & 619.2 & 104.6 & 116.1 & 110.7 & 99.0 & 77.8 & 50.8 & 27.2 & 14.4 & 17.1 & 1.5 \\
\hline $\begin{array}{l}\text { Select red oaks } \\
\text { Yellow birch } \\
\text { Paper birch } \\
\text { Sugar maple } \\
\text { Red maple } \\
\text { Beech } \\
\text { Ash } \\
\text { Aspen } \\
\text { Black cherry } \\
\text { Other hardwoods }\end{array}$ & $\begin{array}{r}110.0 \\
167.4 \\
167.0 \\
562.7 \\
254.1 \\
124.3 \\
118.1 \\
77.2 \\
32.7 \\
109.5\end{array}$ & \begin{tabular}{r|r|}
7.8 \\
27.5 \\
39.4 \\
72.8 \\
42.5 \\
17.6 \\
23.8 \\
14.2 \\
5.5 \\
20.5 \\
\end{tabular} & $\begin{array}{r}14.6 \\
27.6 \\
36.8 \\
97.0 \\
54.2 \\
23.9 \\
24.9 \\
20.1 \\
5.8 \\
19.6\end{array}$ & $\begin{array}{r}14.3 \\
28.6 \\
34.6 \\
108.4 \\
46.4 \\
15.6 \\
21.6 \\
20.0 \\
9.6 \\
23.5 \\
\end{array}$ & \begin{tabular}{r|}
18.0 \\
28.4 \\
25.6 \\
91.1 \\
43.2 \\
16.5 \\
22.4 \\
10.9 \\
5.3 \\
20.3
\end{tabular} & \begin{tabular}{r|}
21.1 \\
17.3 \\
14.6 \\
66.8 \\
30.2 \\
22.5 \\
12.5 \\
6.8 \\
1.6 \\
10.8
\end{tabular} & \begin{tabular}{r|}
12.3 \\
17.3 \\
7.2 \\
49.6 \\
16.7 \\
13.5 \\
7.7 \\
2.2 \\
1.6 \\
5.4
\end{tabular} & $\begin{array}{r}12.1 \\
8.0 \\
3.8 \\
28.1 \\
7.5 \\
5.8 \\
2.8 \\
1.5 \\
1.6 \\
2.4\end{array}$ & $\begin{array}{r}5.6 \\
5.7 \\
1.5 \\
19.6 \\
4.6 \\
4.9 \\
.2 \\
.8 \\
1.2 \\
1.1\end{array}$ & $\begin{array}{r}2.8 \\
6.5 \\
3.5 \\
25.1 \\
8.0 \\
4.0 \\
2.1 \\
.7 \\
.5 \\
5.2\end{array}$ & $\begin{array}{r}1.4 \\
.5 \\
4.2 \\
.8 \\
.1 \\
\frac{.1}{.7}\end{array}$ \\
\hline Total hardwoods & $1,723.0$ & 271.6 & 324.5 & 322.6 & 281.7 & 204.2 & 133.5 & 73.6 & 45.2 & 58.4 & 7.7 \\
\hline All species & $2,342.2$ & 376.2 & 440.6 & 433.3 & 380.7 & 282.0 & 184.3 & 100.8 & 59.6 & 75.5 & 9.2 \\
\hline
\end{tabular}

Table 50. - Net volume of sawtimber on commercial forest land in Northern geographic unit, by species and diameter classes, Vermont, 1973

[In millions of board feet ${ }^{a}$

\begin{tabular}{|c|c|c|c|c|c|c|c|c|c|}
\hline \multirow[b]{2}{*}{ Species } & \multirow{2}{*}{$\begin{array}{c}\text { All } \\
\text { classes }\end{array}$} & \multicolumn{8}{|c|}{ Diameter class (inches at breast height) } \\
\hline & & $\begin{array}{l}9.0- \\
10.9 \\
\end{array}$ & $\begin{array}{l}11.0- \\
12.9\end{array}$ & $\begin{array}{l}13.0- \\
14.9 \\
\end{array}$ & $\begin{array}{l}15.0- \\
16.9 \\
\end{array}$ & $\begin{array}{l}17.0- \\
18.9 \\
\end{array}$ & $\begin{array}{l}19.0- \\
20.9 \\
\end{array}$ & $\begin{array}{l}21.0- \\
28.9 \\
\end{array}$ & $29.0^{+}$ \\
\hline White and red pine & 404.2 & 60.1 & 64.5 & 65.0 & 47.6 & 49.5 & 28.9 & 78.6 & $\overline{10.0}$ \\
\hline Balsam fir & 465.4 & 237.9 & 128.4 & 64.6 & 26.3 & 8.2 & - & - & - \\
\hline & 814.9 & 299.6 & 220.8 & 137.8 & 89.7 & 30.8 & 19.9 & 16.3 & - \\
\hline Hemlock & 501.6 & 131.6 & 126.2 & 112.5 & 47.2 & 33.3 & 37.2 & 13.6 & - \\
\hline Other softwoods & 109.6 & 52.6 & 33.8 & 11.0 & 6.3 & 5.6 & - & .3 & - \\
\hline Total softwoods & $2,295.7$ & 781.8 & 573.7 & 390.9 & 217.1 & 127.4 & 86.0 & 108.8 & 10.0 \\
\hline Select red oaks & 11.3 & - & .5 & 2.9 & - & - & .1 & 7.8 & \\
\hline Yellow birch & 397.5 & - & 79.0 & 100.7 & 84.4 & 51.4 & 34.1 & 35.0 & 12.9 \\
\hline Paper birch & 108 & - & 49.7 & 32.6 & 18.8 & 7.3 & & & \\
\hline Sugar maple & $1,168.9$ & - & 332.7 & 249.8 & 154.0 & 158.1 & 68.7 & 174.1 & 31.5 \\
\hline Red maple & 302.3 & - & 130.7 & 74.9 & 46.7 & 25.0 & 15.8 & 7.1 & 2.1 \\
\hline & & - & 62.0 & 93.6 & 47.4 & 51.4 & 21.7 & 15.1 & \\
\hline Ast & 116. & - & 50.2 & 32.1 & 11.6 & 10.3 & 3.2 & 6.2 & 2.5 \\
\hline Asp & 62. & - & 18.6 & 29.3 & 11.5 & 2.8 & - & - & - \\
\hline cherry & 27. & 一 & 7.7 & 8.0 & 9.7 & 2.0 & .2 & - & \\
\hline Other hardwoods & 110.9 & - & 39.0 & 21.1 & 11.1 & 16.6 & 7.6 & 10.2 & 5.3 \\
\hline Total hardwoods & $2,596.7$ & - & 770.1 & 645.0 & 395.2 & 324.9 & 151.4 & 255.8 & $\overline{54.3}$ \\
\hline All species & $4,892.4$ & 781.8 & $1,343.8$ & $1,035.9$ & 612.3 & 452.3 & 237.4 & 364.6 & 64.3 \\
\hline
\end{tabular}

International $1 / 4$-inch rule. 
Table 51.-Net volume of sawtimber on commercial forest land in Southern geographic unit, by species and diameter classes, Vermont, 1973

[In millions of board feet] ${ }^{a}$

\begin{tabular}{|c|c|c|c|c|c|c|c|c|c|}
\hline \multirow[b]{2}{*}{ Species } & \multirow[b]{2}{*}{$\begin{array}{c}\text { All } \\
\text { classes }\end{array}$} & \multicolumn{8}{|c|}{ Diameter class (inches at breast height) } \\
\hline & & $\begin{array}{r}9.0- \\
10.9\end{array}$ & $\begin{array}{l}11.0- \\
12.9\end{array}$ & $\begin{array}{l}13.0- \\
14.9\end{array}$ & $\begin{array}{l}15.0- \\
16.9\end{array}$ & $\begin{array}{l}17.0- \\
18.9\end{array}$ & $\begin{array}{l}19.0- \\
20.9\end{array}$ & $\begin{array}{l}21.0- \\
28.9\end{array}$ & 29.0 \\
\hline $\begin{array}{l}\text { White and red pine } \\
\text { Balsam fir }\end{array}$ & 666.2 & 142.7 & 120.4 & 125.2 & 119.0 & 77.6 & 24.2 & 50.2 & 6.9 \\
\hline $\begin{array}{l}\text { Balsam fir } \\
\text { Spruce }\end{array}$ & $\begin{array}{l}19.9 \\
327.1\end{array}$ & $\begin{array}{l}15.2 \\
89.4\end{array}$ & 99.5 & 85.5 & 34.3 & $5 \overline{7}$ & 7.5 & $5 . \overline{2}$ & - \\
\hline Hemlock & 549.0 & 114.5 & 159.3 & 111.8 & 69.8 & 39.0 & 33.0 & 21.6 & - \\
\hline Other softwoods & 17.6 & 6.0 & 8.3 & 3.2 & .1 & - & - & - & $=$ \\
\hline Total softwoods & $1,579.8$ & 367.8 & 392.0 & 325.8 & 223.3 & 122.3 & 64.7 & 77.0 & 6.9 \\
\hline Select red oaks & 303.7 & - & 65.5 & 86.0 & 53.0 & 54.9 & 24.8 & 13.2 & 6.3 \\
\hline Yellow birch & 339.0 & - & 101.8 & 69.5 & 74.9 & 36.2 & 24.6 & 29.8 & 2.2 \\
\hline Paper birch & 224.5 & - & 92.5 & 59.3 & 31.9 & 17.4 & 6.7 & 16.7 & \\
\hline Sugar maple & $1,156.5$ & - & $\begin{array}{l}327.3 \\
1569\end{array}$ & 268.8 & 212.3 & 126.2 & 85.9 & 115.8 & 20.2 \\
\hline Beech & 270.2 & Z & 59.3 & 89.1 & 57.5 . & $\begin{array}{l}32.4 \\
24.8\end{array}$ & 21.4 & $\begin{array}{l}38.0 \\
18.1\end{array}$ & -3.9 \\
\hline Ash & 189.5 & - & 81.0 & 51.0 & 32.9 & 12.9 & .8 & 10.4 & .5 \\
\hline Asper & 91.5 & - & 39.9 & 28.1 & 9.5 & 6.5 & 4.0 & 3.5 & - \\
\hline Black & 46. & - & 19.2 & 6.0 & 7.2 & 6.6 & 5.3 & 2.3 & - \\
\hline Other hardwoods & 184.8 & - & 74.1 & 43.9 & 23.4 & 11.0 & 4.7 & 24.5 & 3.2 \\
\hline Total hardwoods & $3,248.5$ & - & $1,017.5$ & 821.3 & 573.1 & 328.9 & 198.6 & 272.8 & 36.3 \\
\hline All species & $4,828.3$ & 367.8 & $1,409.5$ & $1,147.1$ & 796.4 & 451.2 & 263.3 & 349.8 & 43.2 \\
\hline
\end{tabular}

anternational $1 / 4$-inch rule.

Table 52. - Net volume of sawtimber on commercial forest land in Northern geographic unit, by species and standard-lumber log grades, Vermont, 1973

[In millions of board feet] ${ }^{\mathrm{a}}$

\begin{tabular}{|c|c|c|c|c|c|}
\hline \multirow{2}{*}{ Species } & \multirow{2}{*}{$\underset{\text { classes }}{\text { All }}$} & \multicolumn{4}{|c|}{ Standard-lumber log grades } \\
\hline & & Grade 1 & Grade 2 & Grade 3 & Grade 4b \\
\hline $\begin{array}{l}\text { Softwoods: } \\
\text { White pine } \\
\text { Red pine } \\
\text { Other softwoods }{ }^{c}\end{array}$ & $\begin{array}{r}382.2 \\
22.0 \\
1,891.5\end{array}$ & $\begin{array}{l}7.6 \\
2.7 \\
-\end{array}$ & $\begin{array}{r}53.3 \\
4.4 \\
-\end{array}$ & $\begin{array}{r}204.2 \\
11.7 \\
-\end{array}$ & $\begin{array}{r}117.1 \\
3.2 \\
\end{array}$ \\
\hline Total softwoods & $2,295.7$ & 10.3 & 57.7 & 215.9 & 120.3 \\
\hline $\begin{array}{l}\text { Hardwoods: } \\
\text { Select red oaks } \\
\text { Yellow birch } \\
\text { Paper birch } \\
\text { Sugar maple } \\
\text { Red maple } \\
\text { Beech } \\
\text { Ash } \\
\text { Aspen } \\
\text { Black cherry } \\
\text { Other hardwoods }\end{array}$ & $\begin{array}{r}11.3 \\
397.5 \\
108.7 \\
1,168.9 \\
302.3 \\
291.2 \\
116.1 \\
62.2 \\
27.6 \\
110.9 \\
\end{array}$ & $\begin{array}{r}1.3 \\
47.1 \\
8.9 \\
168.0 \\
5.2 \\
5.8 \\
10.9 \\
-\overline{1.6} \\
11.5 \\
\end{array}$ & $\begin{array}{r}3.1 \\
105.6 \\
32.4 \\
269.5 \\
58.7 \\
50.8 \\
33.6 \\
4.7 \\
6.7 \\
18.3 \\
\end{array}$ & $\begin{array}{r}4.3 \\
208.4 \\
53.9 \\
526.1 \\
166.7 \\
164.6 \\
51.0 \\
41.9 \\
10.8 \\
67.6 \\
\end{array}$ & $\begin{array}{r}2.6 \\
36.4 \\
13.5 \\
205.3 \\
71.7 \\
70.0 \\
20.6 \\
15.6 \\
8.5 \\
13.5 \\
\end{array}$ \\
\hline Total hardwoods & $2,596.7$ & 260.3 & 583.4 & $1,295.3$ & 457.7 \\
\hline & & & $n$ percent & & \\
\hline Hardwood quality & 100 & 10 & 22 & 50 & 18 \\
\hline
\end{tabular}

a International $1 / 4$-inch rule.

bGrade 4 applies only to the pines. For hardwoods the volumes in this column are for construc. tion logs.

c Softwood species other than pine are not graded. 
Table 53. - Net volume of sawtimber on commercial forest land in Southern geographic unit, by species and standard-lumber log grades, Vermont, 1973

[In millions of board feet $]^{\mathrm{a}}$

\begin{tabular}{|c|c|c|c|c|c|}
\hline \multirow{2}{*}{ Species } & \multirow{2}{*}{$\begin{array}{c}\text { All } \\
\text { classes }\end{array}$} & \multicolumn{4}{|c|}{ Standard-lumber logs } \\
\hline & & Grade 1 & Grade 2 & Grade 3 & Grade $4^{b}$ \\
\hline $\begin{array}{l}\text { Softwoods: } \\
\text { White pine } \\
\text { Red pine } \\
\text { Other softwoods }{ }^{c}\end{array}$ & $\begin{array}{r}613.2 \\
53.0 \\
913.6 \\
\end{array}$ & $\begin{array}{r}4.2 \\
.3 \\
- \\
\end{array}$ & $\begin{array}{r}38.9 \\
.3 \\
-\end{array}$ & $\begin{array}{r}298.8 \\
39.3 \\
- \\
\end{array}$ & $\begin{array}{r}271.3 \\
13.1 \\
-\end{array}$ \\
\hline Total softwoods & $1,579.8$ & 4.5 & 39.2 & 338.1 & 284.4 \\
\hline $\begin{array}{l}\text { Hardwoods: } \\
\text { Select red oaks } \\
\text { Yellow birch } \\
\text { Paper birch } \\
\text { Sugar maple } \\
\text { Red maple } \\
\text { Beech } \\
\text { Ash } \\
\text { Aspen } \\
\text { Black cherry } \\
\text { Other hardwoods }\end{array}$ & $\begin{array}{r}303.7 \\
339.0 \\
224.5 \\
1,156.5 \\
442.2 \\
270.2 \\
189.5 \\
91.5 \\
46.6 \\
184.8 \\
\end{array}$ & $\begin{array}{r}53.0 \\
24.8 \\
17.5 \\
112.4 \\
15.0 \\
5.4 \\
24.1 \\
2.7 \\
2.0 \\
10.5 \\
\end{array}$ & $\begin{array}{r}68.0 \\
84.6 \\
31.9 \\
264.4 \\
80.1 \\
30.2 \\
65.6 \\
11.4 \\
9.7 \\
30.6 \\
\end{array}$ & $\begin{array}{r}136.6 \\
193.6 \\
107.4 \\
574.0 \\
229.7 \\
169.7 \\
60.3 \\
51.5 \\
23.9 \\
102.0 \\
\end{array}$ & $\begin{array}{r}46.1 \\
36.0 \\
67.7 \\
205.7 \\
117.4 \\
64.9 \\
39.6 \\
25.9 \\
11.0 \\
41.7 \\
\end{array}$ \\
\hline Total hardwoods & $3,248.5$ & 267.4 & 676.4 & $1,648.7$ & 656.0 \\
\hline Hardwood quality & 100 & 8 & $\begin{array}{c}\text { In percent } \\
21\end{array}$ & 51 & 20 \\
\hline
\end{tabular}

a International $1 / 4$-inch rule.

bGrade 4 applies only to the pines. For hardwoods the volumes in this column are for construction logs.

${ }^{c}$ Softwood species other than pine are not graded. 


\section{METRIC EQUIVALENTS OF UNITS USED IN THIS REPORT}

1 acre $=4,046.86$ square meters or 0.405 hectare.

1,000 acres $=405$ hectares.

$1,000,000$ acres $=405,000$ hectares.

$1,000$ board feet (International $1 / 4$-inch log rule $)=3.48$ cubic meters.

$1,000,000$ board feet (International 1/4-inch log rule) =3,480 cubic meters.

Breast height $=1.4$ meters above ground level.

1 cubic foot $=28,317$ cubic centimeters or 0.028317 cubic meter.

1,000 cubic feet $=28.317$ cubic meters.

$1,000,000$ cubic feet $=28,317$ cubic meters.

1 cord (wood, bark, and airspace) $=3.6246$ cubic meters

1 cord (solid wood, pulpwood) $=2.4069$ cubic meters .

1 cord (solid wood, other than pulpwood) $=2.2654$ cubic meters

1,000 cords (pulpwood) $=2,406.9$ cubic meters.

1,000 cords (other products) $=2,265.4$ cubic meters.

1 foot $=30.48$ centimeters or 0.3048 meter.

1 inch $=25.4$ millimeters or 2.54 centimeters or 0.0254 meter.

1 mile $=1.609$ kilometers .

1 square foot $=929.03$ square centimeters or 0.0929 square meter. 

Headquarters of the Northeastern Forest Experiment Station are in Upper Darby, $\mathrm{Pa}$. Field laboratories and research units are maintained at:

- Amherst, Massachusetts, in cooperation with the University of Massachusetts.

- Beltsville, Maryland.

- Berea, Kentucky, in cooperation with Berea College.

- Burlington, Vermont, in cooperation with the University of Vermont.

- Delaware, Ohio.

- Durham, New Hampshire, in cooperation with the University of New Hampshire.

- Hamden, Connecticut, in cooperation with Yale University.

- Kingston, Pennsylvania.

- Morgantown, West Virginia, in cooperation with West Virginia University, Morgantown.

- Orono, Maine, in cooperation with the University of Maine, Orono.

- Parsons, West Virginia.

- Pennington, New Jersey.

- Princeton, West Virginia.

- Syracuse, New York, in cooperation with the State University of New York College of Environmental Sciences and Forestry at Syracuse University, Syracuse.

- Warren, Pennsylvania. 


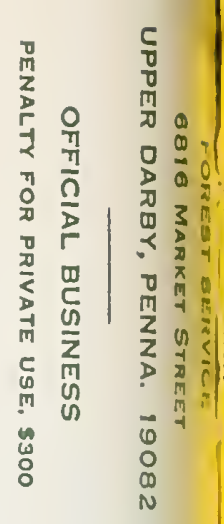

$\frac{\Gamma}{00}$
20
$D$
2

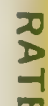

$m$
0
$c$
0
2
$\frac{1}{1}$
0
2
2
2

$\frac{3}{D}$ 